
$\mathbb{1}$ Nordic Council
of Ministers

\title{
REFRIGERATION UNITS IN MARINE VESSELS
}

Alternatives to HCFCs and high GWP HFCs

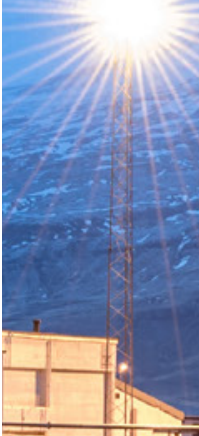

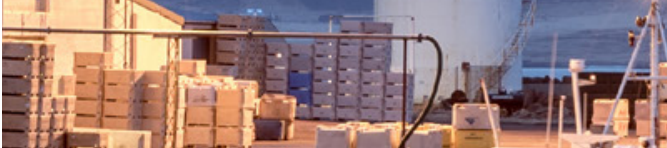

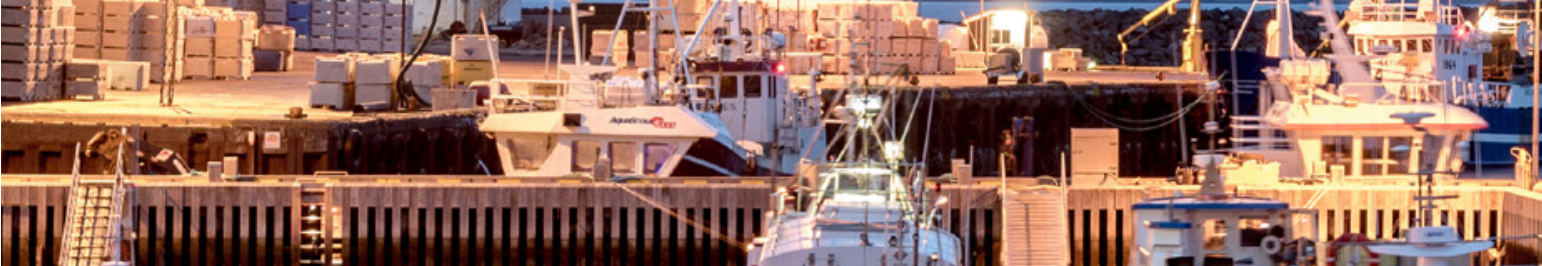
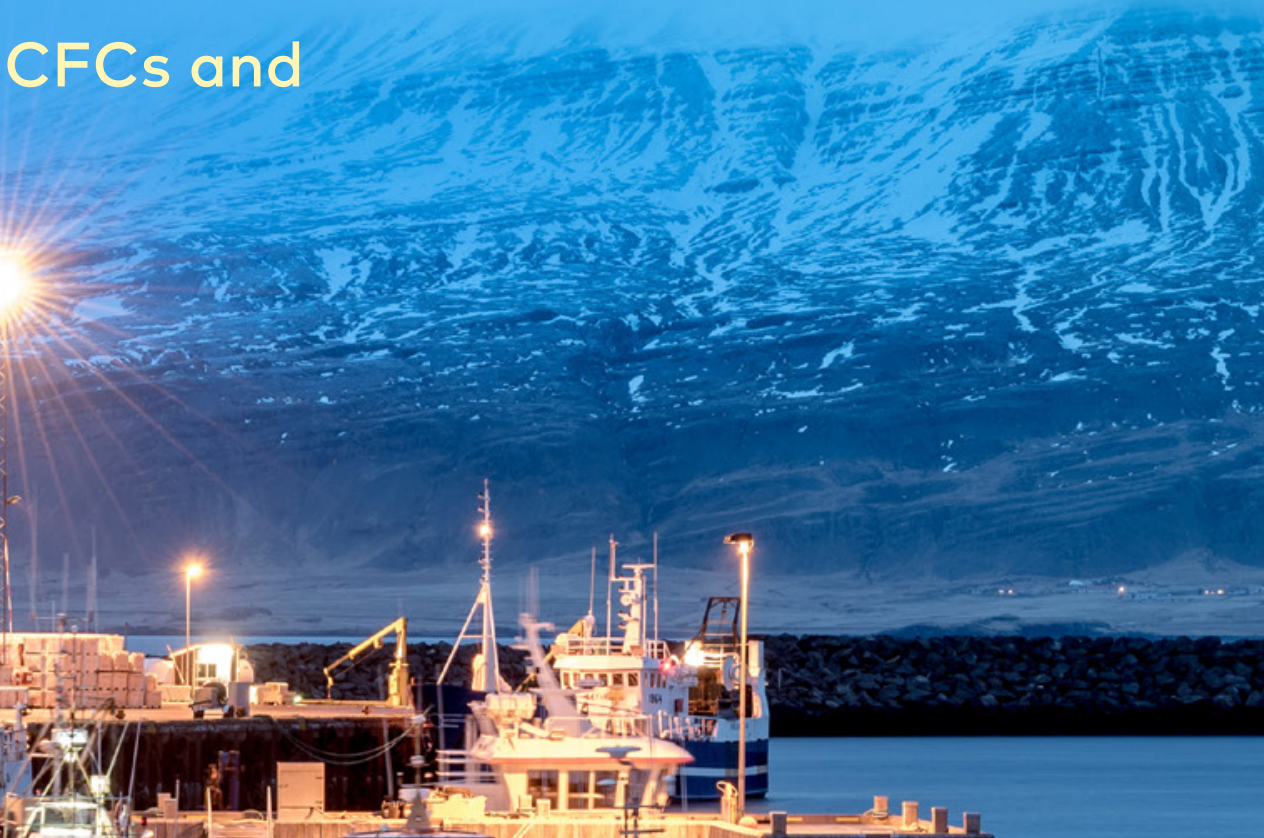

IT)
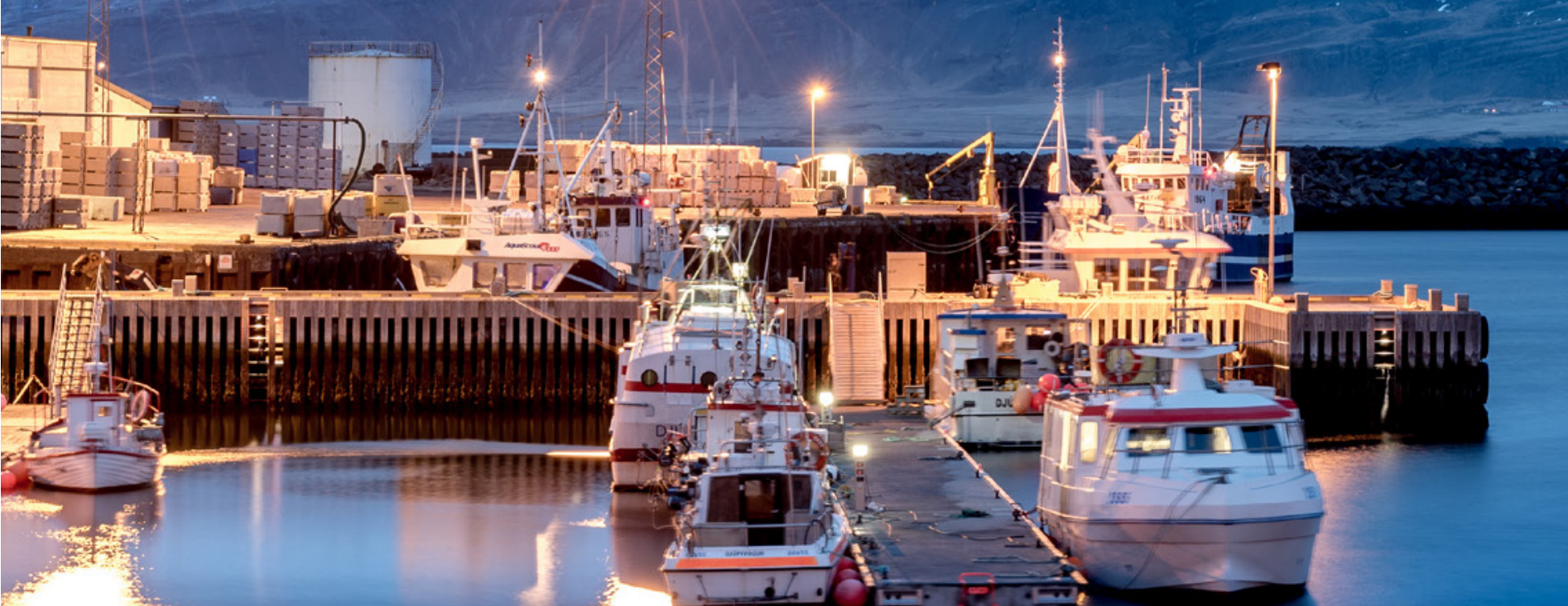
3.
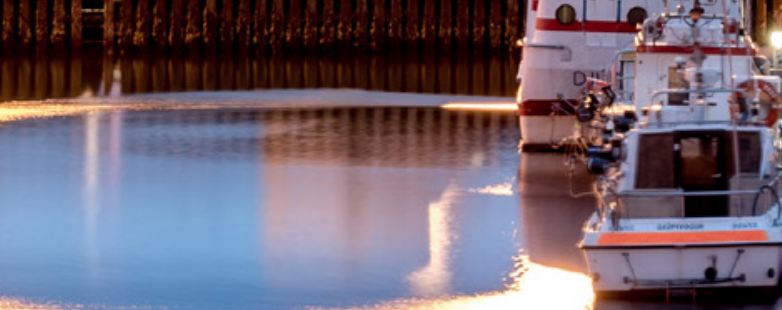

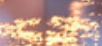
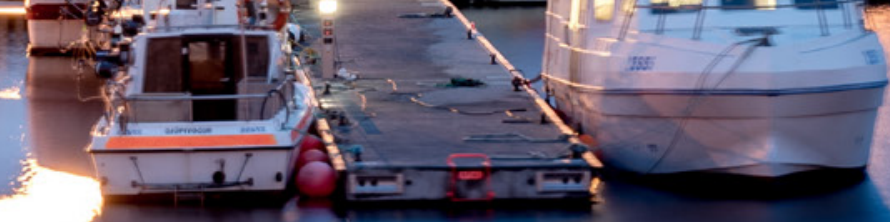



\section{Refrigeration units in marine vessels}

Alternatives to HCFCs and high GWP HFCs

Prof. Dr.-Ing. A. Hafner, Dr. C.H. Gabrielii and Dr. K. Widell

TemaNord 2019:527 
Refrigeration units in marine vessels

Alternatives to HCFCs and high GWP HFCs

Prof. Dr.-Ing. A. Hafner, Dr. C.H. Gabrielii and Dr. K. Widell

ISBN 978-92-893-5940-5 (PRINT)

ISBN 978-92-893-5941-2 (PDF)

ISBN 978-92-893-5942-9 (EPUB)

http://dx.doi.org/10.6027/TN2019-527

TemaNord 2019:527

ISSN 0908-6692

Standard: PDF/UA-1

ISO 14289-1

(c) Nordic Council of Ministers 2018

Cover photo: Shutterstock

\section{Disclaimer}

This publication was funded by the Nordic Council of Ministers. However, the content does not necessarily reflect the Nordic Council of Ministers' views, opinions, attitudes or recommendations.

Rights and permissions

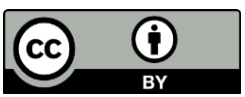

This work is made available under the Creative Commons Attribution 4.0 International license (CC BY 4.0) https://creativecommons.org/licenses/by/4.0

Translations: If you translate this work, please include the following disclaimer: This translation was not produced by the Nordic Council of Ministers and should not be construed as official. The Nordic Council of Ministers cannot be held responsible for the translation or any errors in it.

Adaptations: If you adapt this work, please include the following disclaimer along with the attribution: This is an adaptation of an original work by the Nordic Council of Ministers. Responsibility for the views and opinions expressed in the adaptation rests solely with its author(s). The views and opinions in this adaptation have not been approved by the Nordic Council of Ministers.

Third-party content: The Nordic Council of Ministers does not necessarily own every single part of this work. The Nordic Council of Ministers cannot, therefore, guarantee that the reuse of third-party content does not infringe the copyright of the third party. If you wish to reuse any third-party content, you bear the risks associated with any such rights violations. You are responsible for determining whether there is a need to obtain permission for the use of third-party content, and if so, for obtaining the relevant permission from the copyright holder. Examples of third-party content may include, but are not limited to, tables, figures or images. 
Photo rights (further permission required for reuse):

Any queries regarding rights and licences should be addressed to:

Nordic Council of Ministers/Publication Unit

Ved Stranden 18

DK-1061 Copenhagen K

Denmark

Phone +4533960200

pub@norden.org

\section{Nordic co-operation}

Nordic co-operation is one of the world's most extensive forms of regional collaboration, involving Denmark, Finland, Iceland, Norway, Sweden, and the Faroe Islands, Greenland and Åland.

Nordic co-operation has firm traditions in politics, economics and culture and plays an important role in European and international forums. The Nordic community strives for a strong Nordic Region in a strong Europe.

Nordic co-operation promotes regional interests and values in a global world. The values shared by the Nordic countries help make the region one of the most innovative and competitive in the world.

\section{The Nordic Council of Ministers}

Nordens Hus

Ved Stranden 18

DK-1061 Copenhagen K, Denmark

Tel.: +4533960200

www.norden.org

Download Nordic publications at www.norden.org/nordpub 



\section{Contents}

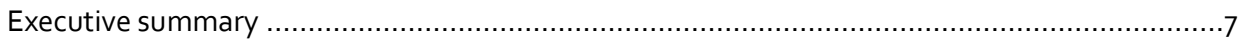

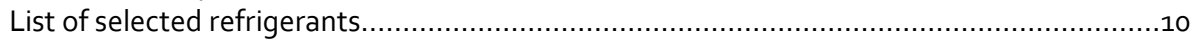

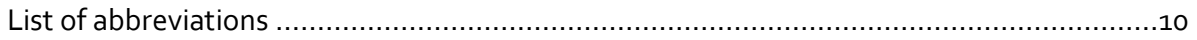

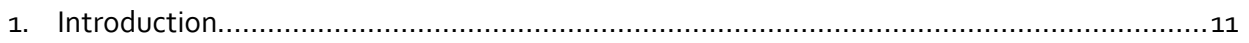

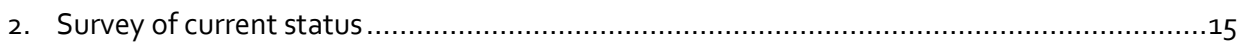

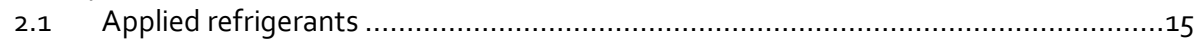

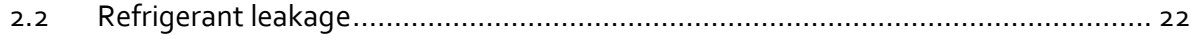

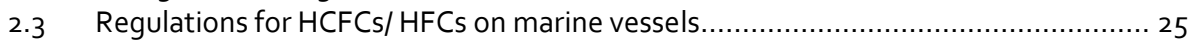

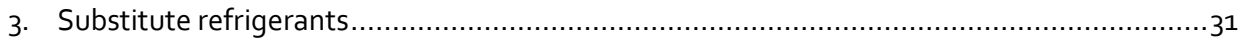

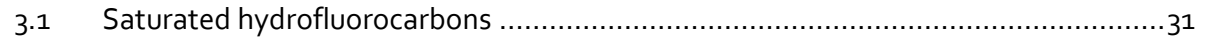

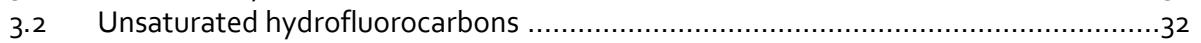

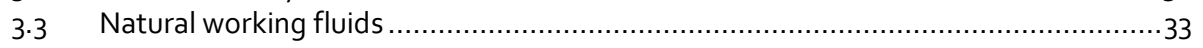

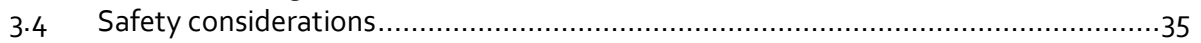

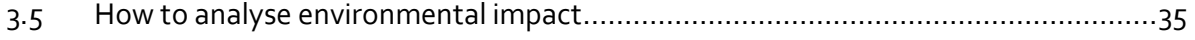

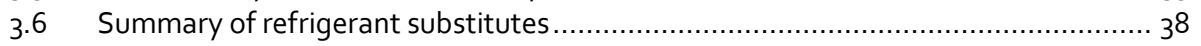

4. Examples of refrigeration systems on different types of vessels ................................. 39

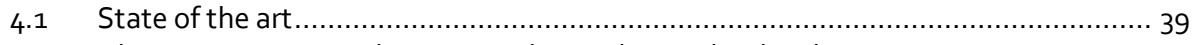

4.2 Alternative system solutions (on the market/under development) .......................50

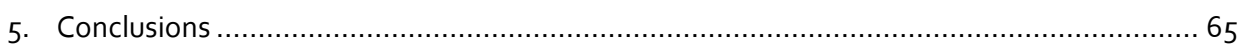

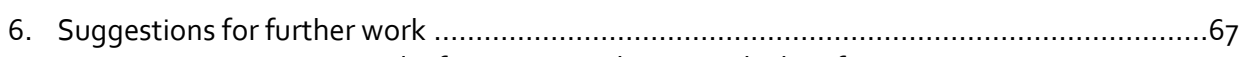

6.1 Communication and information exchange with classification societies .................67

6.2 Support for dissemination of measurement results from pilot/demonstration plants

on board various kind of ships ................................................................ 68

6.3 Establish a Nordic Technology Hub for global marine refrigeration research and

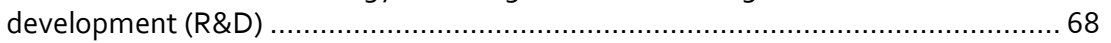

6.4 Development support for dedicated components ............................................ 69

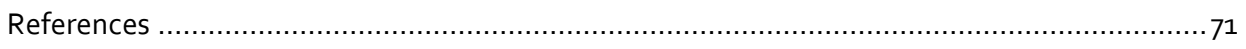

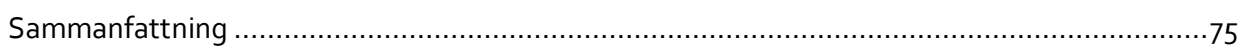

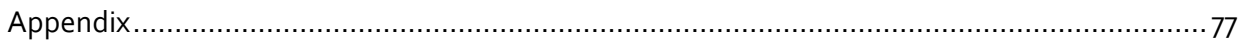




\section{Executive summary}

This report describes refrigeration equipment on board marine vessels, with a focus on the Nordic countries and the achievements made with systems applying natural working fluids. In fishing vessels, the refrigeration units are mainly applied for cooling or freezing of the catch. In passenger ships and cargo vessels the refrigeration plants do have a wide range of cooling capacities, mainly to provide comfort to passengers and crew with air conditioning and to preserve food.

According to the International Maritime Organisation the total use of HCFC/HFC as refrigerant in the world merchant fleet is estimated to consist of $70 \% \mathrm{R} 22,26 \% \mathrm{R} 134 \mathrm{a}$ and $4 \% \mathrm{R}_{4} 04 \mathrm{~A}(\mathrm{IMO}, 2014)$. The release of refrigerants from global shipping (reefer containers excluded) is estimated at 8,400 tons, which corresponds to around 15 million tons $\mathrm{CO}_{2}$ equivalent emissions. If these numbers are compared to the $\mathrm{CO}_{2}$ emissions of shipping the refrigerant emissions constitute about $2 \%$ of the GHG emissions of shipping.

In Europe, refrigerants that are legal to use in marine refrigeration units, after the ban of ozone depleting substances like R22, can be grouped as follows:

- saturated hydrofluorocarbons (HFCs);

- unsaturated hydrofluorocarbons (called Hydrofluorolefins, HFOs);

- natural working fluids.

All refrigerants from the first group affect the climate and the environment. Therefore, HFCs applied and released from refrigeration units are the major substances of the current F-gas programs, such as the EU Regulation No 517/2014 on fluorinated greenhouse gases and the Montreal protocol on substances that deplete the ozone layer. There are less harmful hydrofluorocarbons with relatively low global warming potential (GWP) values, however, these fluids are classified as flammable and require therefore risk assessments and special safety mitigations measures. The newly introduced HFOs have a very short atmospheric lifetime, due to their chemical structure, the double bond. Short atmospheric lifetime is the main reason for the ultralow GWP values of HFOs. However, this takes neither the greenhouse gas emissions from the production into consideration, nor the environmental impact of the decomposition products. The risks related to the use of HFOs and their blends when it comes to human health, safety and the environmental impact of decomposition products are not fully understood yet ( $M-917 / 2017)$. In the past, numerous cases are on record where new chemicals, believed to be a benefit to man, have turned out to be environmentally unacceptable, sometimes even in quite small quantities.

Therefore, as a precautionary approach for the people on board marine vessels and to secure the investments, the recommendation for the entire maritime sector is to 
convert the current refrigeration units from HFCs directly to natural working fluids. New orders should only request for units applying natural working fluids (not just specifying for low-GWP options). Thereby, avoiding both costly retrofit actions in the future and higher operational costs, when applying non-natural working fluids. The energy efficiency of refrigeration units applying natural working fluids is higher when comparing the performance with traditional HFC and HFO based units.

There are also safety issues with natural working fluids. Proper and well-known technical safety strategies are solving these issues, i.e. applying globally available technology. The chemical behaviour of natural working fluids is fully understood and accepted globally as well as their environmental impacts, and the utilisation as energy efficient and legal refrigerants. Ammonia (R717) is toxic, but has been successfully applied in refrigeration systems in the last 150 years. Carbon dioxide (R744) is the only non-flammable $A_{1}$ fluid with a neglectable GWP and provides excellent thermodynamic, fluiddynamic and heat transfer properties. To protect people in case of refrigerant leakage, safety equipment to detect harmful $\mathrm{CO}_{2}$ concentrations in machine rooms etc. is standard equipment and globally available. R744 units do have high working pressures, which is not a technical issue, rather an advantage, achieving significant size reductions of pipe- and component dimensions, due to high fluid densities compared to conventional systems. Size requirements are important issues on board marine vessels, where space and pipe passways are always limited. A limitation for current R744 units is that today's compressors are capacity wise not large enough, therefore several parallel compressors are necessary for cooling and freezing systems, when requiring megawatts of cooling capacity. The supply industry will solve this challenge in the near future, since larger capacity compressors are in the design stage at several leading manufacturers. However, the maritime sector can play an important role in accelerating these compressor developments.

Risk related to flammability of natural working fluids as when applying hydrocarbons as working fluid for chillers, can be prevented by reduced charge systems and well-trained operators. In case of a fire, hydrocarbons do not decompose into highly toxic products, as is the case for all HFCs and HFOs.

The following application areas are feasible for the phase in of natural working fluids, successful state of the art and demonstration units. The report shows the details, while the table below is a summary. 
Table 1: A summary of feasible natural working fluid alternatives for different applications

\begin{tabular}{|c|c|c|c|c|}
\hline Type & Fishing vessels & Passenger-/Cruise ships & Cargo ships & Others \\
\hline $\begin{array}{l}\text { Purpose of main } \\
\text { refrigeration } \\
\text { equipment }\end{array}$ & $\begin{array}{l}\text { Chilling/freezing of } \\
\text { the catch }\end{array}$ & $\begin{array}{l}\text { Air conditioning and } \\
\text { provision cooling/ } \\
\text { freezing }\end{array}$ & $\begin{array}{l}\text { Maintain } \\
\text { temperature inside } \\
\text { the hold, air } \\
\text { conditioning }\end{array}$ & Air conditioning \\
\hline $\begin{array}{l}\text { Current working } \\
\text { fluids }\end{array}$ & $\begin{array}{l}\text { Globally: R22 } \\
\text { Europe: R22/HFC } \\
\text { Nordic: R717, R744 } \\
\text { and HFCs }\end{array}$ & $\begin{array}{l}\text { Nordic: } \mathrm{HFC} \\
\text { Globally: } \mathrm{R}_{22}, \mathrm{HFCS} \\
\mathrm{CO}_{2} \text { for provision } \\
\text { cooling and freezing }\end{array}$ & $\begin{array}{l}\text { Nordic: HFC } \\
\text { Globally: R22, HFC }\end{array}$ & \\
\hline $\begin{array}{l}\text { Challenges with } \\
\text { current working } \\
\text { fluids }\end{array}$ & $\begin{array}{l}\text { Fast phase out of R22 } \\
\text { required } \\
\text { High cost of HFCs, } \\
\text { due to shortage in the } \\
\text { European market (EU } \\
\text { Regulation) } \\
\text { Safety requirements } \\
\text { for R717 equipment }\end{array}$ & \multicolumn{3}{|c|}{$\begin{array}{l}\text { Fast phase out of R22 required } \\
\text { High cost of HFCs, due to shortage in the European market (EU } \\
\text { Regulation) }\end{array}$} \\
\hline $\begin{array}{l}\text { Alternative/future } \\
\text { working fluids }\end{array}$ & R717 and $R_{744}$ & \multicolumn{3}{|c|}{ R717, Hydrocarbons (e.g. R290) and $\mathrm{CO}_{2}$} \\
\hline $\begin{array}{l}\text { Advantage with } \\
\text { alternative working } \\
\text { fluids }\end{array}$ & $\begin{array}{l}\text { R717: well-known and } \\
\text { high energy } \\
\text { efficiency for chilling } \\
\text { equipment } \\
\text { R744: high } \\
\text { performance in deep- } \\
\text { freezing/batch } \\
\text { freezing applications, } \\
\text { non-flammable and } \\
\text { non-toxic }\end{array}$ & $\begin{array}{l}\text { High-energy efficient } \\
\text { chillers for AC units with } \\
\text { R717 and R290 } \\
\text { High-energy efficiency, } \\
\text { global availability, and } \\
\text { safety with R744 for } \\
\text { direct expansion (and } \\
\text { indirect) provision } \\
\text { cooling/freezing units }\end{array}$ & $\begin{array}{l}\text { High-energy efficien } \\
\text { with R717 and R290 }\end{array}$ & chillers for AC units \\
\hline
\end{tabular}

Note: $\mathrm{R}_{744}=\mathrm{CO}_{2} ; \mathrm{R} 717=$ Ammonia.

The recommendation to public funding authorities is to continue and strengthen the good research and development of natural refrigerant systems for marine vessels. It will also be necessary to intensify the knowledge transfer and information distribution to all stakeholders in this sector globally. Therefore, the following actions are proposed:

- Extensive information exchange with classification societies by arranging workshops including DNV GL, Loyds etc. as well the major original equipment manufacturers (OEM) from the Nordic countries and authorities like DSB from Norway;

- Support for dissemination of measurement results from pilot and demonstration plants on board various kinds of ships;

- Establish a Nordic Technology Hub for global marine refrigeration research and development (R\&D);

- Development support for dedicated components:

- compressors for maritime applications;

- heat exchangers. 


\section{List of selected refrigerants}

A more detailed list is included in appendix.

Table 2: List of selected refrigerants

$\begin{array}{llrr}\text { Formula (name) } & \text { Type } & \text { ODP } & \text { GWP }_{100} \\ \text { R12 (freon) } & \text { CFC } & \text { 1 (high) } & 10,900 \\ \text { R22 } & \text { HCFC } & 0.055 \text { (medium) } & 1,810 \\ \text { R404A } & \text { HFC } & 0 & 3,922 \\ \text { R410A } & \text { HFC } & 0 & 2,088 \\ \text { R134a } & \text { HFC } & 0 & 1,430 \\ \text { R32 } & \text { HFC } & 0 & 675 \\ \text { R1234yf(HFO) } & \text { HFC } & 0 & 4 \\ \text { R1234ze (HFO) } & \text { HFC } & 0 & 6 \\ \text { R717 (ammonia) } & \text { Natural } & 0 & 0 \\ \text { R744 (CO }{ }_{2} \text { ) } & \text { Natural } & 0 & 1 \\ \text { R290 (propane) } & \text { Natural } & 0 & 3\end{array}$

\section{List of abbreviations}

$\begin{array}{ll}\text { COP } & \text { Coefficient of performance } \\ \text { DNV } & \text { Det Norske Veritas } \\ \text { EU } & \text { European Union } \\ \text { GL } & \text { Germanischer Lloyd } \\ \text { GWP } & \begin{array}{l}\text { Global Warming Potential. The value is based on a 10o year time scale. } \\ \text { The values is the equivalent amount of CO, released to the atmosphere } \\ \text { contributing to the global warming. The GWP values listed above are }\end{array} \\ & \text { from the Intergovernmental Panel on Climate Change's Fifth } \\ & \begin{array}{l}\text { Assessment Report, published in 2014. Example: } R \text { 134a: GWP of 1430 } \\ \text { Hydrochlorofluorocarbon; organic compounds composed of }\end{array} \\ \text { HCFC } & \text { hydrogen, fluorine, chlorine and carbon atoms } \\ \text { HFC } & \text { Hydrofluorocarbon; organic compounds composed of hydrogen, } \\ & \text { fluorine, and carbon atoms } \\ \text { HFO } & \text { Hydrofluoroolefin; unsaturated organic compounds containing } \\ & \text { hydrogen, fluorine, and carbon atoms } \\ \text { HVAC\&R } & \text { Heating, ventilation, and air conditioning \& Refrigeration } \\ \text { IDLH } & \text { Immediately Dangerous to Life or Health } \\ \text { IMO } & \text { International Maritime Organization } \\ \text { ODP } & \text { Ozone depleting potential } \\ \text { OEM } & \text { Original equipment manufacturer } \\ \text { ORC } & \text { Organic Rankine Cycle } \\ \text { RoRo } & \text { Roll-on/roll-off ships are vessels designed to carry wheeled cargo } \\ \text { RSW } & \text { Refrigerated Seawater } \\ \text { TEWI } & \text { Total equivalent warming impact } \\ \text { TLV } & \text { Threshold Limit Value }\end{array}$




\section{Introduction}

The widespread usage of R22 and the expected transition from HCFC to HFCs in the HVAC\&R systems of marine vessels was directly mentioned during the talks leading to the decision in Kigali; where the global phase down of HFCs was decided at the 28th Meeting of the Parties under the Montreal Protocol. Due to the harsh physical environment on marine vessels, the direct refrigerant emissions are often very high. There is very little information available on how this sector could leapfrog directly towards a refrigeration technology with a low environmental impact.

Around $90 \%$ of world trade is carried by the international shipping industry. There are over 50,000 merchant ships ( $>500 \mathrm{GT}$ ) trading internationally, transporting every kind of cargo (ICS, 2017). In Figure 1 the number of different types of ships (>500 GT) in the world merchant fleet is presented.

Figure 1: Number of ships (>500 GT) in the world merchant fleet in 2017, by type.

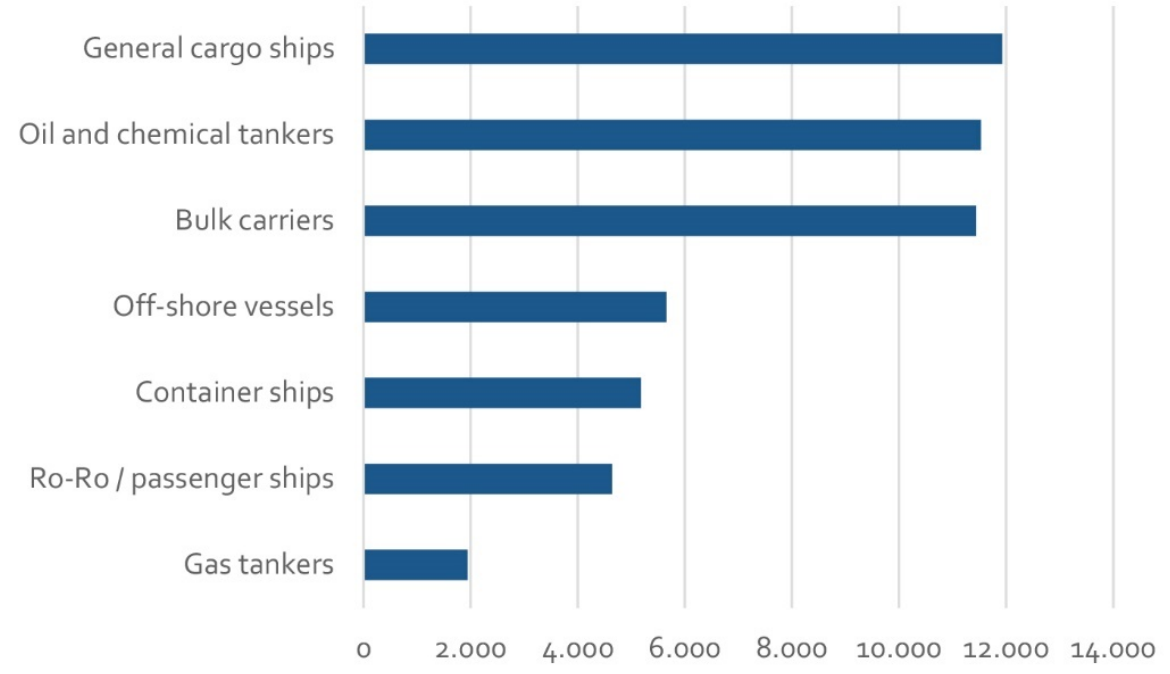

Source: Equasis Statistics, 2017.

If including smaller ships (100-499 GT) the number of ships in the world merchant fleet is almost 90,000 (Equasis Statistics, 2017). According to the International Maritime Organisation the total use of HCFC/HFC as refrigerant in the world merchant fleet is estimated to consist of $70 \% R_{22}, 26 \% R_{13} 4 a$ and $4 \% R_{4} 04 A$ (IMO, 2014). The release of refrigerants from global shipping (reefer containers excluded) is estimated at 8,400 tons, which corresponds to around 15 million tons $\mathrm{CO}_{2}$ equivalent emissions. If these numbers are compared to the $\mathrm{CO}_{2}$ emissions of shipping the refrigerant emissions constitute about $2 \%$ of the $\mathrm{GHG}$ emissions of shipping. 
The EU merchant fleet consists of 12,200 vessels ( $>100 \mathrm{GT}$ ) which is $14 \%$ of the global merchant fleet. Measured in Grosse Tonnes (GT) the share is 18\% (Danish Shipowners' Association, 2016). The number of cargo and passenger ships in the Nordic merchant fleet, and its total gross tonnage are seen in Figure 2 (Statistics Norway, 2012).

Figure 2: The Nordic merchant fleet in number of ships and gross tonnage
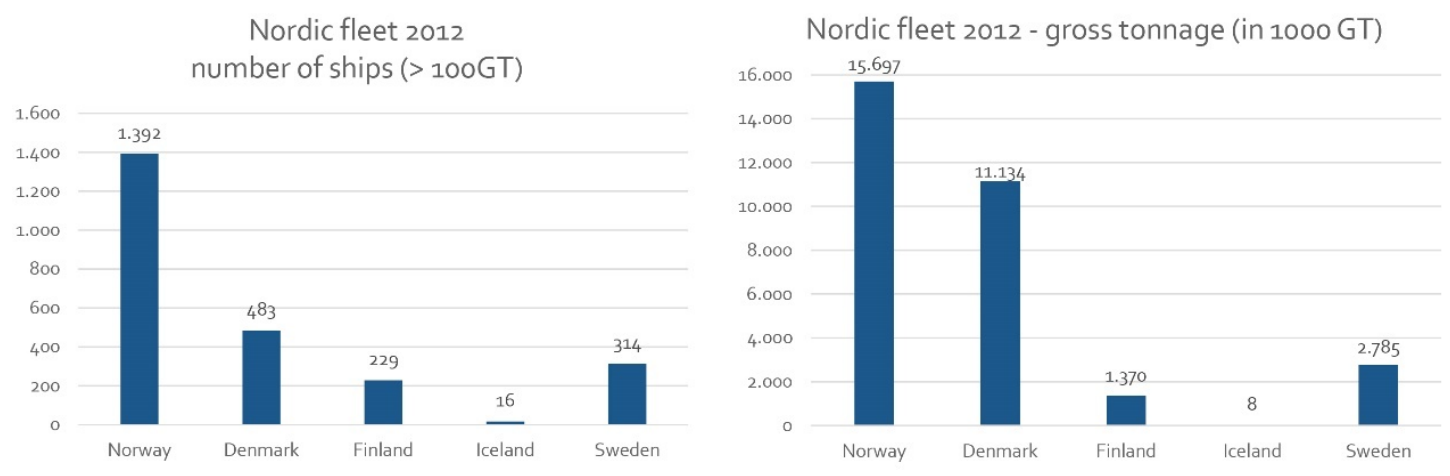

Source: Statistics Norway, 2012.

On a global scale, $70 \%$ of the fishing fleet applies R 22 while $70 \%$ of the fleet, around 3 million vessels are based in the Asian-Pacific region. The majority of the European fishing fleet ( $3 \%$ of the global fleet, $\sim 86,500$ vessels in 2013) consist of boats less than $12 \mathrm{~m}$ in length, while some vessels are even longer than $40 \mathrm{~m}$. To achieve a sustainable exploitation of valuable European fish resources the number of fishing vessels has been reduced since the 1990 .

The current situation in Europe with respect to the fishing sector is shown in Figure 3, Figure 4, Figure 5. The data from Eurostat show the amount of fish catches by nation in 1,000 metric tonnes within the different fishing regions. Norway has the largest total installed engine power followed by Spain and France. The Norwegian fleet has also the largest total gross tonnage followed by Spain and UK. 
Figure 3: Catches of nations by fishing area, by country in 2015 (1,000 metric tonnes live weight)

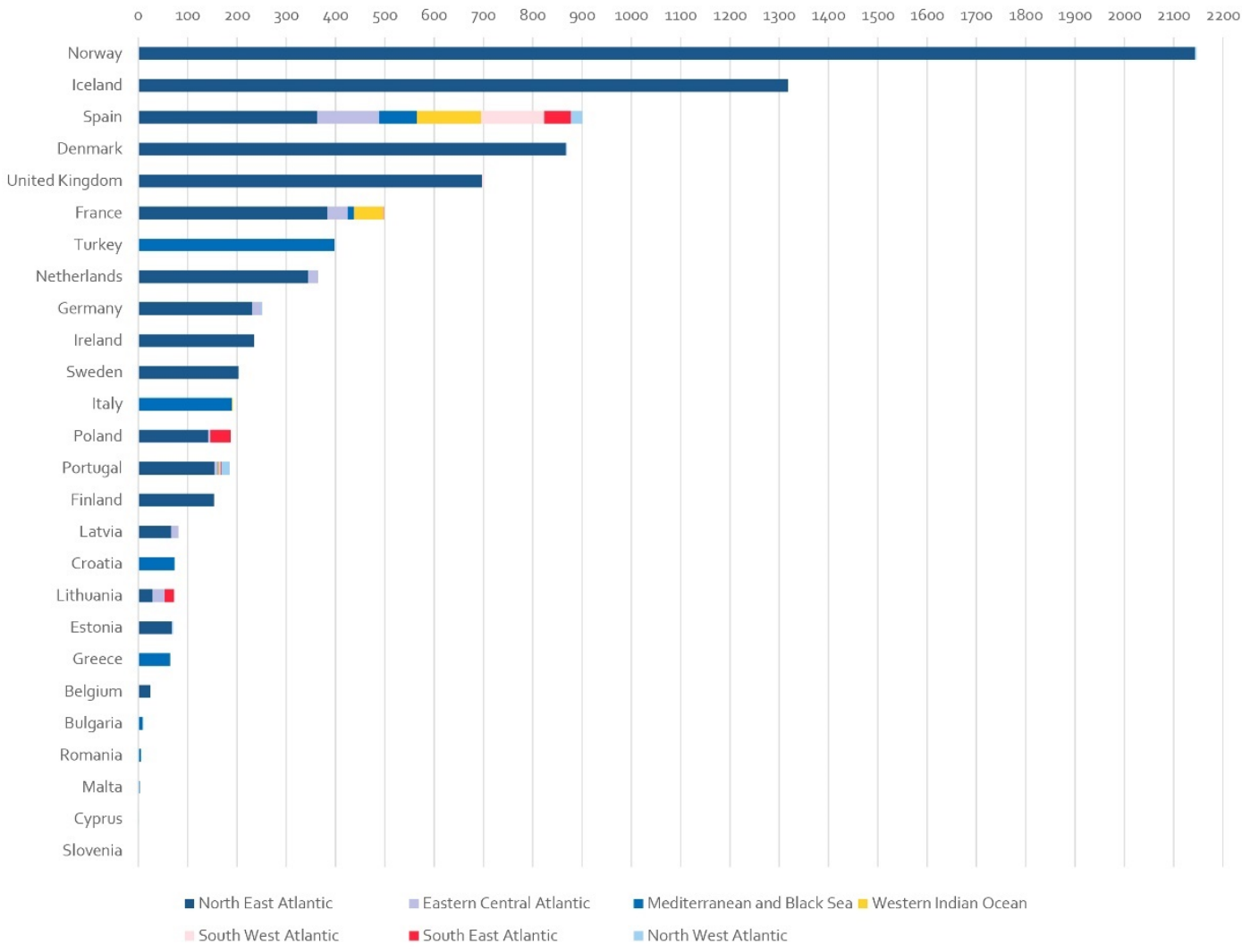

Source: Eurostat (online data code: fish_ca)

Figure 4: European fishing fleet. Total gross tonnage in 2014 in thousands (YB15)

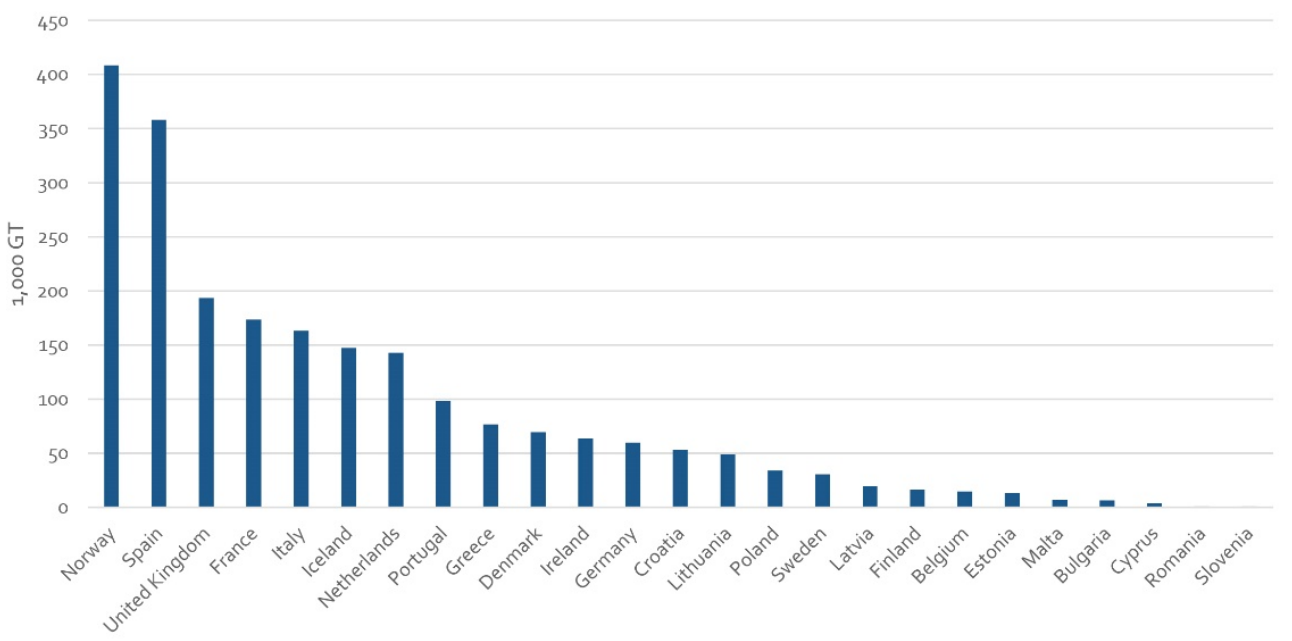

Source: Eurostat (online data code: fish_fleet). 
Figure 5: European fishing fleet. Total installed engine power in 1,000 kW

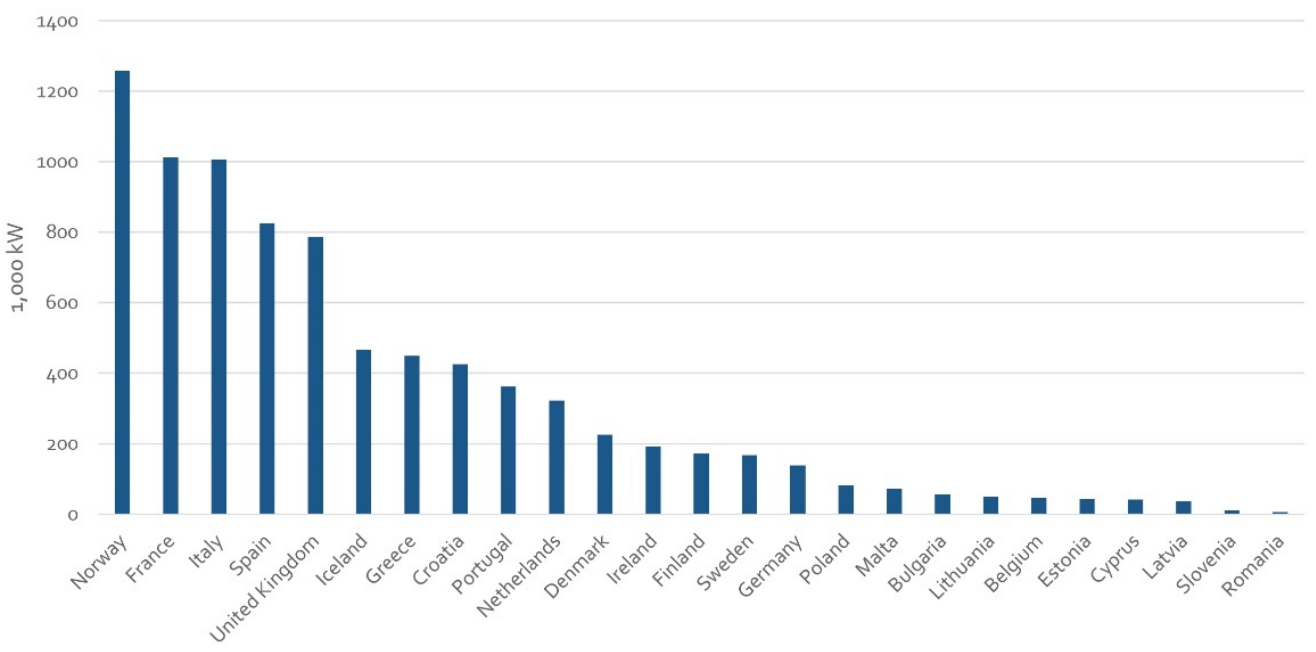

Source: Eurostat (online data code: fish_fleet).

There have been many successful working fluid transitions of HVAC\&R applications from HCFCs, via HFCs towards natural refrigerants during the past 20 years, after the implementation of the Montreal Protocol in developed countries. This report will highlight how such a transition is possible for the marine sector by applying the latest technology achievements and further adapt them if needed due to ambient temperature constrains.

Beside the technological part, a key role will be to get adapted global, regional and national regulations in place, which consider the total environmental impact of the HVAC\&R system and not only the Global Warming Potential (GWP) value of the working fluid. Another important boost for a fast phase in of these technologies are financial support mechanisms to reduce the risks when implementing newly developed technology. This will encourage the vendors to develop the next generation of refrigeration equipment for the maritime sector. At the same time, there has to be a consensus about safety mitigation in close cooperation between vendors, end-users and the maritime classification societies. 


\section{Survey of current status}

\subsection{Applied refrigerants}

The data presented in this survey are mostly from Norwegian fishing vessels and Swedish passenger ships and cargo vessels.

\subsubsection{Fishing vessels}

Many fishing vessels have traditionally used R22 in their refrigeration systems, however, since it has an ozone depleting potential (ODP) of 0.055 , refill/service is not permitted within the EU since 1 January 2015. In Norway, beside some retrofit with HFCs in existing units there has been a clear change to apply natural working fluids for new Refrigerated Sea Water (RSW) and freezing-systems, mainly applying ammonia and $\mathrm{CO}_{2}$.

Size and charge levels of different refrigerants for the different sectors were listed in a report by Tokle et al. (1993). At that time, the fishing fleet included 600 ships, where $91 \%$ had HCFCs, most likely R22 and the rest had CFCs, probably R12. No number was given for any other refrigerant. A report from 2007 (Haukås, 2007) shows a clear change. At that time, $60(14 \%)$ of the fishing vessels had R717 systems, 19 (4\%) had HFCs and the rest, 351 (82\%) still had HCFCs (R22). A report from Sander Poulsen (2011) describes the usage and leakage scenarios of $\mathrm{R}_{22}$ fishing vessels in the Nordic region. According to a survey in 2009, the total amount of R22 in Norwegian fishing vessels was 400 metric ton, in Islandic fishing vessels 200 metric ton, vessels registered in Faroe Islands had about 150 metric ton. By that time the total remaining $R_{22}$ charges in fishing vessels from Finland, Sweden and Denmark was less than 5 metric tons, only 10 large trawlers where applying R22 in Greenland.

According to data reported for Swedish fishing vessels using F-gases (11 vessels) the share of R22 during 2007-2012 was almost $70 \%$. The HFCs in use during that time period were $\mathrm{R}_{404} \mathrm{~A}$, R134a and R507. After 2012 no fishing vessel has reported any use of F-gas anymore.

Hognes and Jensen (2017) analysed fuel consumption and carbon footprint for the Norwegian fishing fleet from 2001 to 2015 . They used data from the Norwegian Directorate of Fisheries, data from a survey that included the answers given for 304 vessels and they did interviews with 146 ship owners. Based on data for fuel consumption and assumed refrigerant leakage, carbon footprint calculations of Norwegian fisheries were performed according to the IPCC guidelines. Calculated $\mathrm{CO}_{2}$ equivalents are shown in Figure 6. The results show that the greenhouse gas emissions from this industry has been steadily reducing during the last decades. This is achieved through improving fuel efficiency and fuel burned per unit of catch landed. Changing from high GWP refrigerants to $R 717$ and $R 744$ has also clearly reduced the carbon footprint. Improved fuel efficiency is 
a result of good resource availability; this is further a result of well managed stocks and a reduction of the number of vessels. Increasing the quotas per vessel and thus their efficiency. On top of this technological developments have led to more efficient fishing gear, catch control, engine and propulsion systems. It was concluded that even though many improvements already have been done, it is still possible to reduce the climate affecting emissions even more.

Figure 6: GHG emissions from 2001 to 2015 for Norwegian based fishing vessels

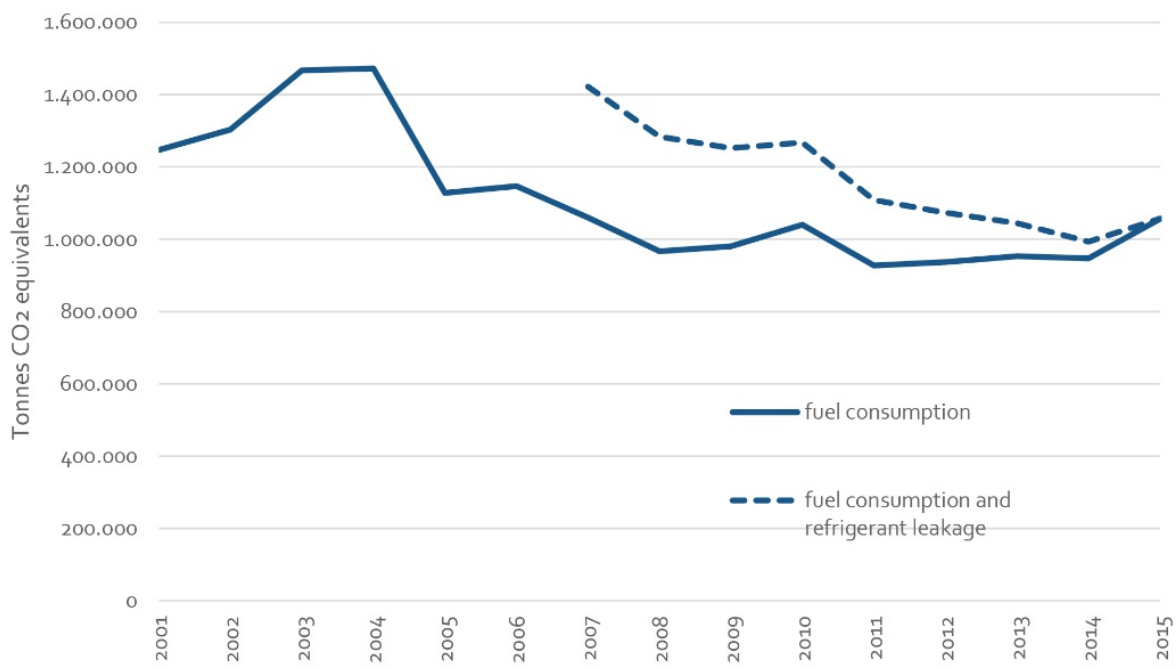

\subsubsection{Passenger vessels and cargo vessels}

Since 2007 every Swedish flagged vessel containing a refrigeration/AC unit with a refrigerant charge of more than $10 \mathrm{~kg} \mathrm{~F}$-gases is obliged to send in an annual report to the Swedish Transport Agency. The report should contain the total amount of F-gas installed and re-filled (as for stationary plants according to the F-gas regulation). In this survey data from two different time periods (2007-2012 and 2013-2016) are presented for around 30 passenger ships and 30 cargo vessels.

Use of R22 on board passenger ships and cargo vessels In Figure 7 the share of R22 of the total amount (by mass) of installed refrigerant is shown. As seen the use of R22 has decreased from $10 \%$ in 2007 to below $0.5 \%$ in 2011, and to $0 \%$ in 2016. 
Figure 7: Share of R22 (\% by mass of total refrigerant) in Swedish vessels

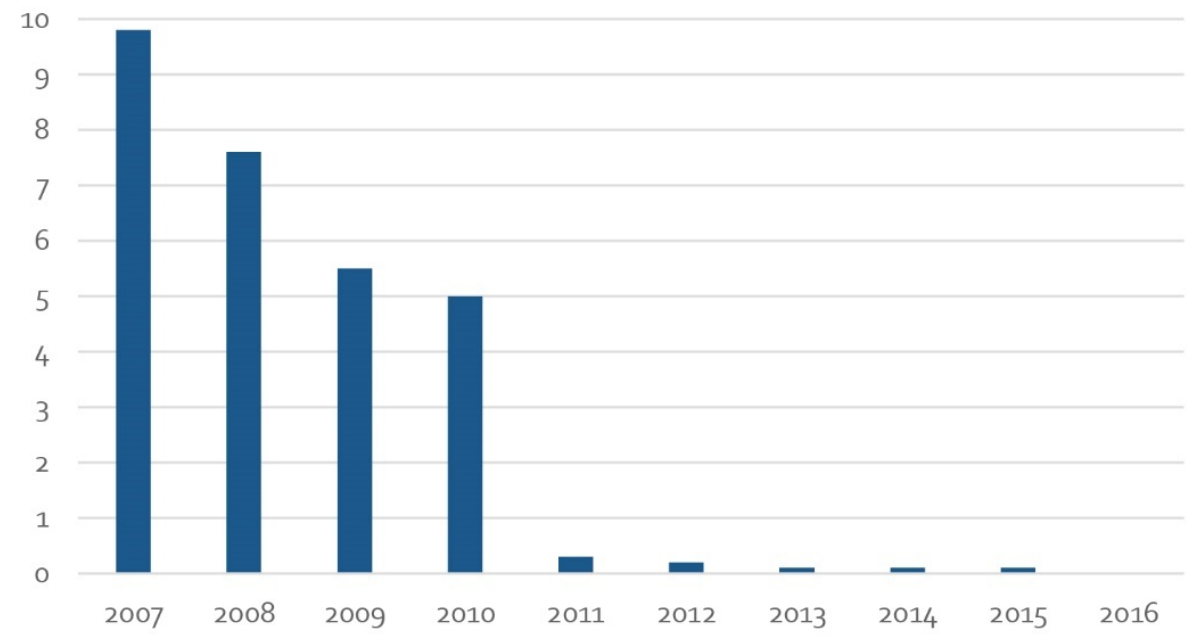

Use of HFCs - Passenger ships

Air conditioning: As seen in Figure 8, the dominating refrigerant for air conditioning plants is R134a. However, if comparing data from the two different periods, the share of $\mathrm{R}_{407} \mathrm{C}$, R404A and R410A has increased, while the share of R507A has decreased. Also, a few "new" drop-in refrigerants for $R_{22}$ have been introduced; R422D and R424A.

Figure 8: Refrigerants for $A C$ units on passenger ships

AC - passenger ships 2007-2012

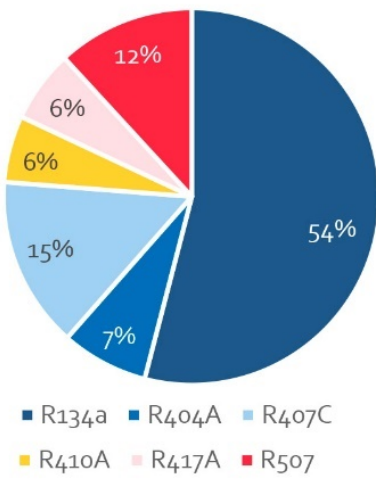

$A C$ - passenger ships 2013-2016

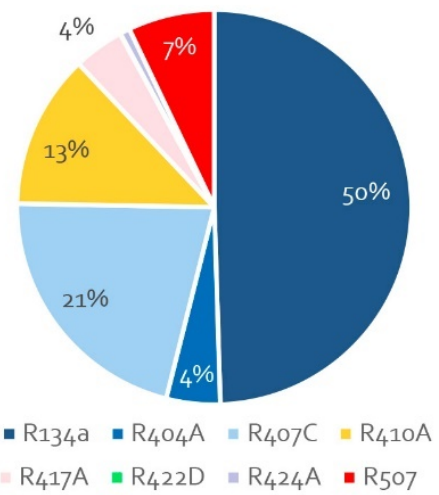

Provision refrigeration: Figure 9 shows the different types of refrigerants installed. As seen, $\mathrm{R}_{404 \mathrm{~A}}$ is the dominating refrigerant for provision refrigeration. However, if comparing the two different time periods the share of $\mathrm{R}_{404} \mathrm{~A}$, and $\mathrm{R}_{507}$, has somewhat decreased, while the share of $\mathrm{R}_{407} \mathrm{C}$ has increased. There are also some systems using R134a and R422A. 
There is only one ship reporting the usage of different refrigerants for chilling and freezing application ( $\mathrm{R}_{407} \mathrm{C}$ and $\mathrm{R}_{404} \mathrm{~A}$, respectively). Besides provision cooling and freezing store rooms passenger ships report large amounts of refrigerant installed in refrigerated cabinets (food storage and distribution in restaurants and shops on board; e.g. 150 kg R404A per ship).

Figure 9: Refrigerants for provision refrigeration units on passenger ships

\section{Provision refr. passenger ships} 2007-2012

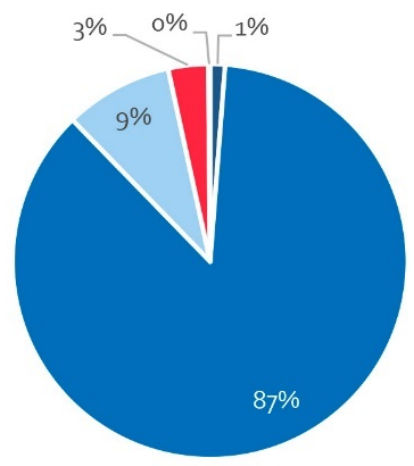

- $\mathrm{R}_{134 \mathrm{a}}=\mathrm{R}_{404} \mathrm{~A}=\mathrm{R}_{407} \mathrm{C}=\mathrm{R}_{507}=\mathrm{R}_{22}$

\section{Provision refr. passenger ships} 2013-2016

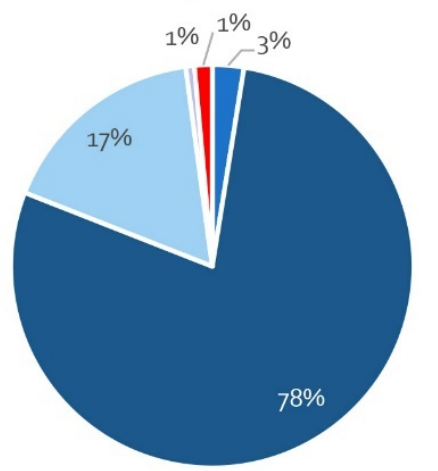

- R134a - R404A = R407C $=\mathrm{R}_{422} \mathrm{~A}=\mathrm{R}_{507 \mathrm{~A}}$

Use of HFCs - cargo vessels

The data presented for cargo vessels are divided in RoRo ${ }^{1}$ vessels (of which many are vehicle carriers) and tanker vessels (mostly product/chemical tankers).

Air conditioning: The refrigerants used on board of RoRo and tanker vessels are presented in Figure 10 and Figure 11 and respectively. As seen, the amount of $\mathrm{R}_{4} \mathrm{O} 4 \mathrm{~A}$ has decreased considerably for both types of cargo vessels. A probable reason for the larger use of R404A between 2007 and 2012 is the conversion from $R_{22}$ to $R_{404} A$, in order to use the same refrigerant in all $\mathrm{AC} /$ refrigeration systems on board.

For RoRo ships today (Figure 10 right), R 134 a and R407C are dominating with about an equal share, while for tanker ships $\mathrm{R}_{407} \mathrm{C}$ is highly dominating, and there are no installations using R134a (Figure 11 right).

${ }^{1}$ Roll-on/roll-off (RoRo) ships are vessels designed to carry wheeled cargo. 
Figure 10: Refrigerants for $A C$ units on RoRo vessels

\section{AC on RoRo vessels \\ 2007-2012}

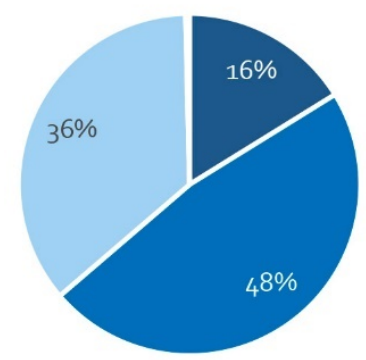

- R134a $=\mathrm{R}_{404} \mathrm{~A}=\mathrm{R}_{407 \mathrm{C}}=\mathrm{R}_{410} \mathrm{~A}=\mathrm{R}_{417} \mathrm{~A}$

Figure 11: Refrigerants for AC units on tankers

AC on tankers 2007-2012

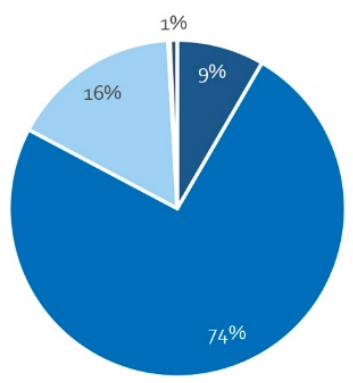

- $\mathrm{R}_{134 \mathrm{a}}$ - $\mathrm{R}_{404} \mathrm{~A}=\mathrm{R}_{407} \mathrm{C}=\mathrm{R}_{410} \mathrm{~A}=\mathrm{R}_{22}$
AC on RoRo vessels 2013-2016

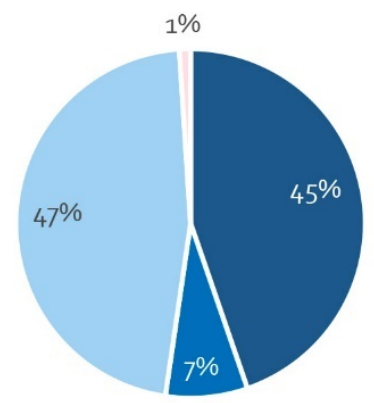

- R134a - R404A $=\mathrm{R}_{407 \mathrm{C}}=\mathrm{R} 417 \mathrm{~A}$
AC on tankers 2013-2016

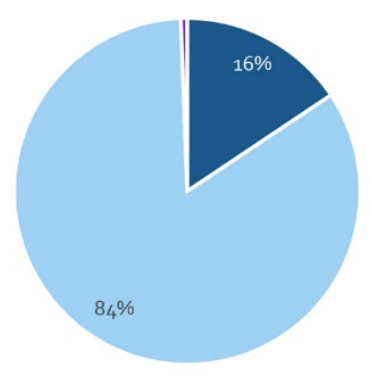

- $\mathrm{R}_{404} \mathrm{~A}=\mathrm{R}_{407} \mathrm{C}$ - $\mathrm{R}_{22}$

Provision refrigeration: The refrigerants used for provision refrigeration on cargo vessels are presented in Figure 12 for RoRo ships and in Figure 13 for tanker vessels.

As seen, for provision refrigeration on cargo ships, the share of R404A has increased during the time period investigated and it is today the dominating refrigerant, especially in tanker ships, where no other refrigerant than $\mathrm{R}_{404} \mathrm{~A}$ is used. For RoRo ships, there are some ships using $\mathrm{R}_{407} \mathrm{C}$ and a few using the "new" refrigerant R422A. During 2007-2012 also R417A was used, which is a drop-in replacement for $R 22$. 
Figure 12: Refrigerants for provision refrigeration units on RoRo vessels

\section{Provision refrigeration RoRo 2007-2012}

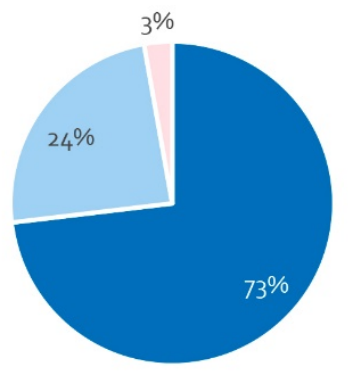

- $\mathrm{R}_{404} \mathrm{~A}=\mathrm{R}_{407} \mathrm{C}=\mathrm{R}_{417} \mathrm{~A}$
Provision refrigeration RoRo

2013-2016

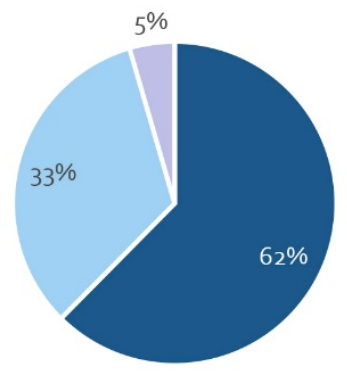

- $\mathrm{R}_{404} \mathrm{~A}=\mathrm{R}_{407} \mathrm{C}=\mathrm{R}_{422} \mathrm{~A}$

Figure 13: Refrigerants for provision refrigeration units on tankers

Provision refrigeration tankers

2007-2012

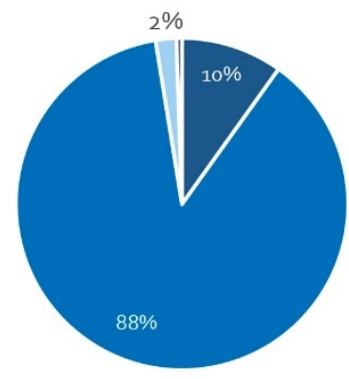

- R134a - R404A = R407C - $\mathrm{R}_{22}$
Provision refrigeration tankers 2013-2016

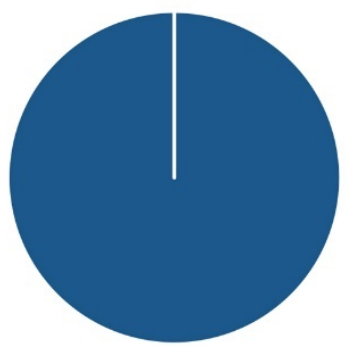

- R404A

Comparison between passenger ships and cargo ships.

In Figure 14 amount of charged refrigerant per ship is shown, for the two different time periods. Even if the data from the two different time periods are not totally comparable, since it is not exactly the same ships that have been reported, it indicates that the amount of charged refrigerant for $A C$ units on passenger ships has decreased from $626 \mathrm{~kg}$ (in average per ship) to $512 \mathrm{~kg}$. This could be explained by more ships using indirect systems.

For cargo vessels, the data shows that the amount of refrigerant used in units for provision refrigeration has been decreased. However, all tanker vessels are not obliged to report their use of provision refrigerant (if the charge is below $10 \mathrm{~kg} \mathrm{~F}$-gas), and since 
it is not exactly the same ships that have been reported this is the probable reason for this decrease.

Figure 14: Charge of HFC per ship
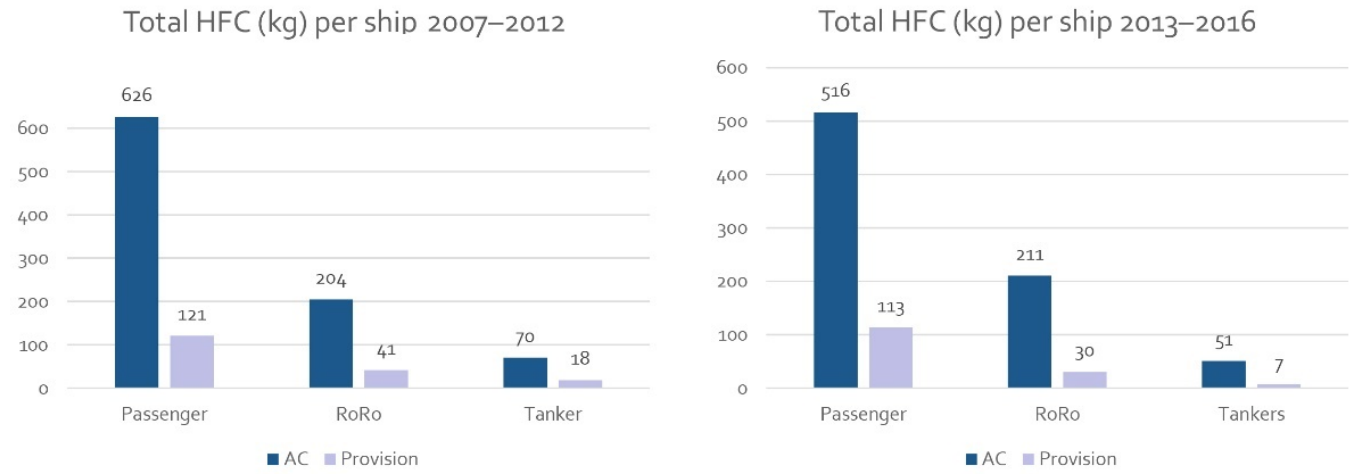

In Figure 15 the amount of the different types of refrigerants on different types of ships, during the two different time periods are presented, and summarizes section 2.1.2.

Figure 15: Amount of various HFCs per ship
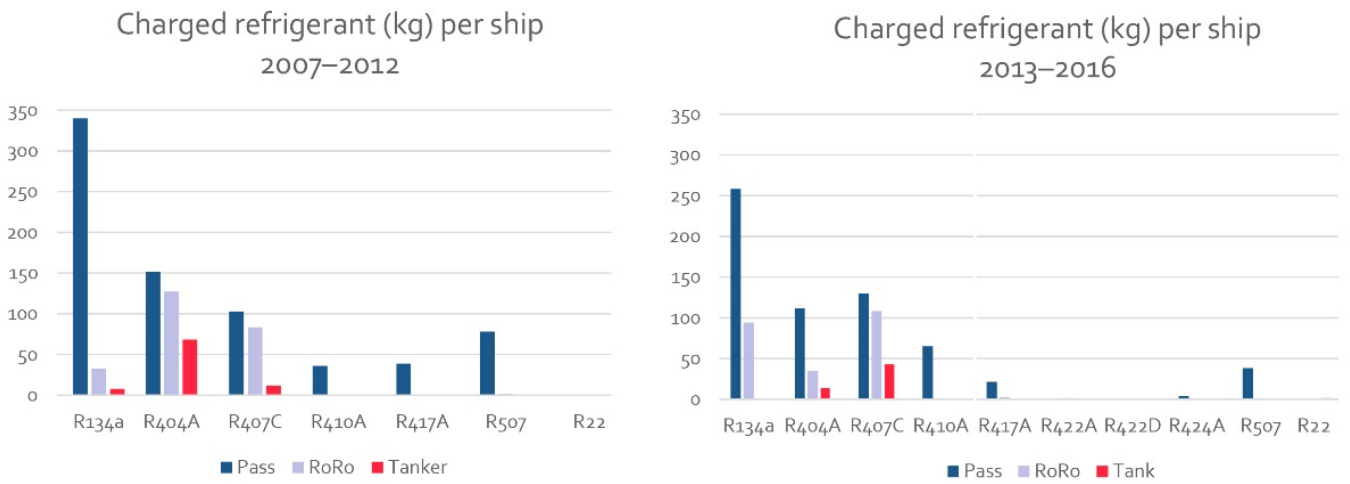

Additional input from refrigeration vendors

According to personal communication with Wilhelmsen Ship Service AS, R404A is still the most installed refrigerant in new-builds. One reason is that most of the ship-owners prefers handling only one type of refrigerant on board. However, the recommended refrigerant by Wilhelmsen is $\mathrm{R}_{407 \mathrm{~F}}$. It is also possible to retrofit/fill-up an existing R404A-plant with R407F.

Wilhelmsen has, during the last ten years, made refrigerant retrofits from R22 on many hundreds of ships (not only Nordic vessels), mostly to R417A (requires no refrigerant-oil change). In addition, Kylkontroll Göteborg $A B$ has made some refrigerant changes from $R_{22}$ to $R_{417} A$, but their experience is that it is not a good option for freezing applications. 
Kylkontroll Göteborg $A B$ has also made some refrigerant changes from $\mathrm{R}_{404} \mathrm{~A}$ to $\mathrm{R}_{42} \mathrm{~A}$, which, however, has a GWP just above 2,000 and results in a capacity reduction of $5 \%$.

\subsubsection{Other applications for HFCs on board marine vessels}

Apart from AC and provision refrigeration, there are some other applications for HFCs on board, which for Swedish vessels have been reported to the Transport Agency.

Refrigerated storage of $\mathrm{CO}_{2}$ for use in fixed firefighting system

In 2016, many of the RoRo vessels reported use of HFC in a refrigeration plant for keeping $\mathrm{CO}_{2}$ liquefied. The refrigerants used for this purpose is mainly $\mathrm{R}_{4} \mathrm{O}_{4} \mathrm{~A}$, but some systems use $\mathrm{R}_{407} \mathrm{C}$ or $\mathrm{R}_{422 \mathrm{~A}}$. The average installed amount of HFC is $28 \mathrm{~kg}$.

Organic Rankine Cycle (ORC)

One ship (a vehicle carrier) reported the use of HFC as working fluid in their waste heat recovery plant (ORC). The installed amount of working fluid is 1,900 kg R236fa, with a GWP value of 9,800 .

\section{Fixed firefighting systems}

According to companies working with installations of fixed firefighting systems on board ships the most commonly used media is $\mathrm{CO}_{2}$. However, there are also systems using HFCs available for marine installations; Halotron II and FEM200. Out of these two the most commonly used on merchant ships is Halotron IIB (also called "Clean Agent FS-49-C2") which is a mixture of HFC-134a, HFC-125 and R744. The GWP value is 1,598. None of the Swedish flagged ships reported any use of Halotron II. However, through personnel communication with on board personnel it is confirmed that there are Halotron systems in use. This might be explained by the unclearness whether the use of HFCs in firefighting systems should be reported or not.

\subsection{Refrigerant leakage}

\subsubsection{Fishing vessels}

Statistics Norway (ssb.no) have data for Norwegian emissions of HFC gases for different sectors, but no data related to the fishing sector. Researchers from ssb say there is a large likelihood that this sector is recharging refrigeration systems when the vessels are outside Norway, where there are no taxes on high GWP refrigerants.

Hognes and Jensen (2017) made a survey where the results indicate that there are still significant refrigerant losses. They contacted the largest suppliers for refrigeration units, and many fishing vessels.

\subsubsection{Passenger ships and cargo vessels}


In Figure 16, the average annual refrigerant leakage rates for Swedish passenger and cargo vessels are presented based on yearly reported data of the total installed refrigerant and the total refilled refrigerant. The low leakage rate in 2007 is probably because it was the first year during which the ships were obliged to report.

Figure 16: Leakage rates on passenger ships and cargo vessels (refrigerant, $\%$ of installed HFC)

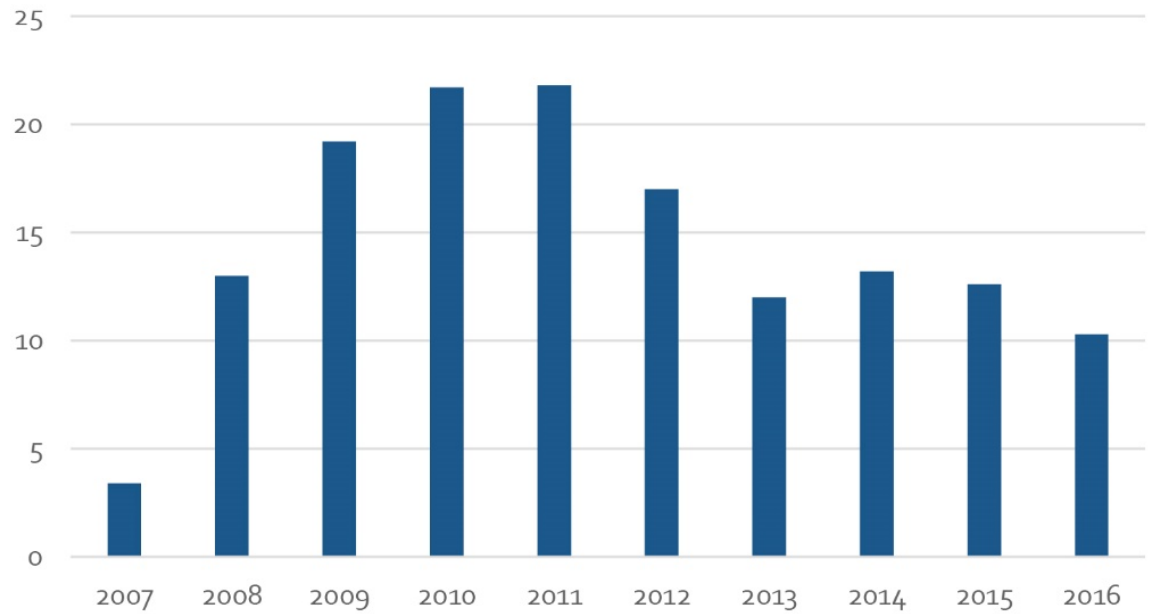

In Figure 17 the reported leakage rates from 2015 and 2016 are presented for each passenger ship and each cargo vessel that has reported any refilled refrigerant. As seen, there is a large spread in the leakage rate; $1-62 \%$.

Figure 17: Reported annual leakage rates per ship (\% of installed amount)

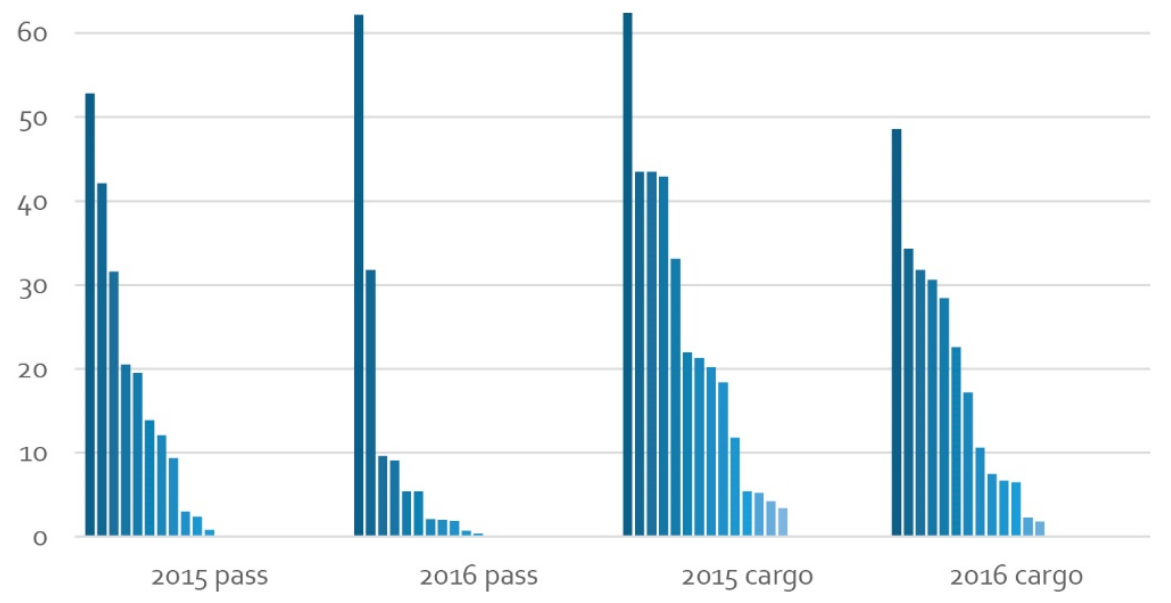

In Figure 18, the average leakage rate for passenger and cargo vessels (excluding the ships that have not reported any refilled amount) are presented. As seen the average leakage rate is larger for cargo vessels, which could be explained by the use of (only) direct systems, which do have extensive pipe networks. 
Figure 18: Reported average leakage rates (\%) for passenger and cargo vessels

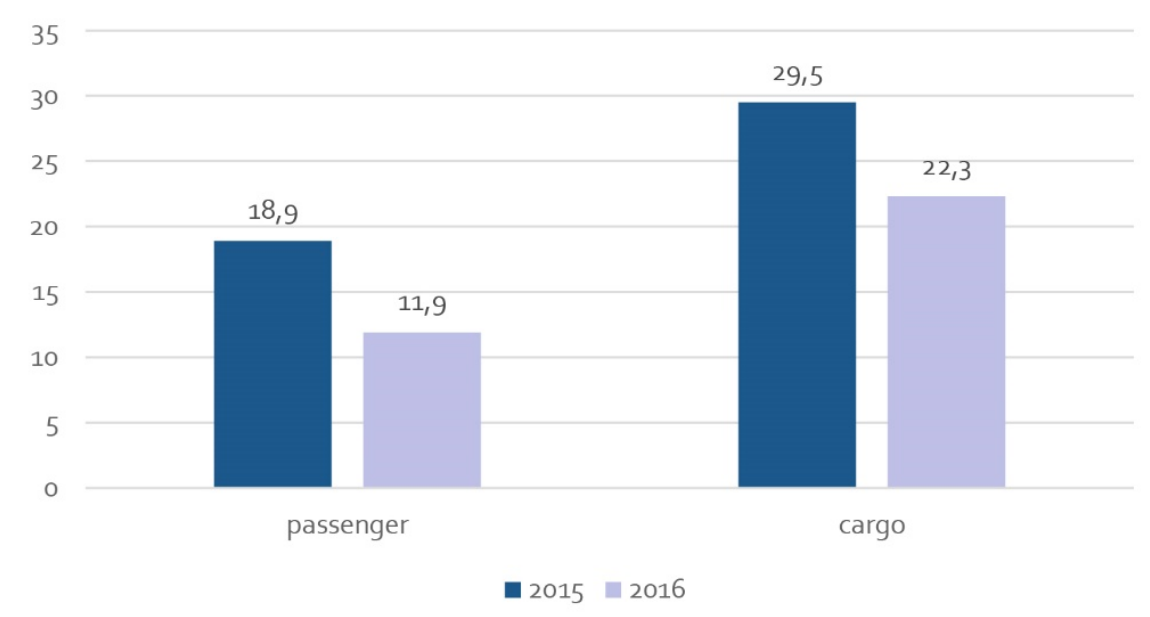

According to correspondence with vendors, the annual leakage rate is $35 \%$ for standard directs systems on cargo vessels (bulk and tankers) and $20 \%$ for large AC chillers on passenger ships. One vendor has experienced that indirect systems have $90 \%$ less leakage rates, due to the compact design and significantly shorter refrigerant lines.

In 2006 a survey of 36 Scandinavian ships with direct $A C$ and provision refrigeration were performed (Schwarz and Rhiemeier, 2007) showing an average leakage rate of $38 \%$, however with large variations in individual leakage rates. In another survey in 2006 (Schwarz and Rhiemeier, 2007) on 10 Baltic ferries with indirect AC and direct provision refrigeration the average annual leakage rate was $21 \%$ for the $A C$ and $25 \%$ for the provision refrigeration systems. Even in this survey large variations were shown; $1-54 \%$ for $A C$, and $0 \%-69 \%$ for provision refrigeration.

\subsubsection{Reasons for refrigerant leakage}

According to Schwarz and Rhiemeier (2007) the main reasons for the high level of emissions from marine vessels, compared to land-based systems are:

- Permanent exposition of the entire system to vibrations from sea-waves;

- The ongoing motion, repeatedly escalating to severe agitation, leads to damages and leakages, especially in the piping parts;

- There are few crewmembers on board skilled in refrigeration. When the ship is at sea for weeks, leakages are not repaired. To achieve cooling, the refrigeration units are simply topped up with refrigerant.

A survey made by Andreasson and Band (2017) investigated the on board personnel's view on why the leakage is larger from ships than from land based plants. A questionnaire was sent out to 12 shipping companies and 25 marine engineers 
answered. Most of them believe that the prime cause is vibrations and breakdowns. However, they also pointed out that inadequate education and usage of equipment causes the leakages.

According to correspondence with refrigeration vendors/service companies their experience regarding refrigerant leakages are:

- The crew's primary duties are focused on ship propulsion, thus maintenance and troubleshooting of the refrigeration plants is given low priority;

- Many plants are, still, built in an old way where the refrigerant compressors and the air fans can be far from each other, thus leading to very long refrigerant pipes;

- Many of the ship's refrigeration plants are old, and worn out, since it is difficult, costly and time consuming to change the entire units;

- $10 \%$ leakage rate ( $10 \%$ reduced charge) means approximately $20 \%$ increase in the plant's energy consumption;

- There is a need for more tight systems especially on board of ships which are subjected to vibrations, dynamic forces etc.;

- Need for higher material quality requirements, for example pipes and joints;

- Need for more detailed material specifications for new installations, in order to avoid "low-price-solutions";

- Need for mandatory record keeping of the amount of installed and refilled refrigerant;

- Need for more stringent control with fines to the shipping companies in case of (large) leakages.

\subsection{Regulations for HCFCs/ HFCs on marine vessels}

\subsubsection{International regulations}

The main regulatory institutions for marine plants are the International Maritime Organization (IMO) and naval registers. The IMOs International Convention MARPOL is the main international convention covering the prevention of pollution of the marine environment by ships from operational or accidental causes (IMO, 2017a).

MARPOL, Annex VI (Regulations for the Prevention of Air Pollution from Ships. Regulation 12 - the use of ozone depletion substances (ODS) in marine applications). New installations containing CFC or Halon are not permitted on ships constructed on or after 19 May 2005, while new installations of HCFC equipment is prohibited after 1 January 2020, both on new and existing ships. Furthermore, it is prohibited to deliberately discharge ODS to the atmosphere; these refrigerants should be collected in a controlled way and be either reused on board or sent to an appropriate facility (IMO, 2017b). 
The GWP of refrigerants is not constrained by any IMO mandatory requirements, thus there are no restrictions for using HFCs on board ships. Some naval registers propose voluntary class notations for refrigeration systems having a low environmental impact, such as a low-GWP refrigerants (see section 1.2.5).

\subsubsection{European regulations}

The first EU Regulation No. 842/2006 on fluorinated greenhouse gases (F-gases) was adopted in 2006 with the aim to reduce emissions of fluorinated greenhouse gases through, for example, periodic leak tests, record keeping, proper recovery and certification. The regulation only applies to stationary equipment, thus not to marine vessels (European Commission, 2006).

In 2014 a new EU Regulation on F-gases, No 517/2014, was adopted, and applies from 1 January 2015 (European Commission, 2014). Except from strengthening the existing leakage prevention measures it also limits the production and use of F-gases. The regulations concerning leakage prevention, record keeping and certification, still does not apply to ships, while the recovery regulation does. There is also a general obligation (for all type of plants) to avoid unintentional HFC-leakages.

However, there is a service ban on existing high GWP-systems that also applies to ships. This means that an equipment on an EU flagged ship using an HFC with a GWP $>2,500$ and an amount corresponding to 40 tonnes $\mathrm{CO}_{2}$ equivalents are prohibited to be recharged with new refrigerant after 1 January 2020 and with recycled refrigerant after 1 January 2030. Furthermore, the limits on the amount of F-gases that can be put on the EU market as well as the ban of using F-gases in many types of new equipment will have an indirect impact also on the shipping sector, such as lower availability and higher price (Gluckmann Consulting, 2016).

It is therefore important to take into consideration in the future planning/planning for investments that the average GWP value of $\mathrm{F}$-gases (calculated as $\mathrm{CO}_{2}$-eq.) imported to the EU will decline according to the schedule specified in Annex $V$ of the regulation. This will have an impact on market availability and prices of refrigerants, especially those with a high GWP, such as R404A, in all applications.

\subsubsection{Nordic regulations}

Sweden: As the only Nordic country, Sweden applies all the F-gas regulation regarding periodic leakage control, record keeping and certification also to Swedish flagged ships (see section 2.3.4) (Transportstyrelsen, 2017).

Norway, Iceland and Denmark (and other EU member states) has implemented the EU F-gas regulation for land-based applications. Thus, the requirements related to regular leak checking, record keeping, reporting, and the use of trained technicians are not mandatory for equipment on board ships.

Finland: According to the Finnish Transport Safety Agency, there are no requirements to report the use of HFCs on board ships. However, the requirements to use certified personnel and keep records of servicing also applies to ships using F-gases. 
Faroe Islands: According to the Faroese Environment Agency there is no obligation to report what type of refrigerants that are used on board. Regarding ODS (HCFCs) the ship-owners/vessels shall report accidental leakages and leakages over $25 \%$ to the Environmental Agency.

\subsubsection{Swedish regulations}

The regulations presented below apply to Swedish flagged ships, except those not calling on any Swedish port during a calendar year.

\section{Periodic leak tests}

As mentioned above, the EU F-gas regulation requires mandatory leak checks for stationary equipment, but not for equipment on board ships. In the Swedish regulation SFS 2016:1128 Förordning om fluorerade växthusgaser (SFS, 2016) mandatory leak tests also apply to equipment that are installed on board ships, if the refrigerant charge is more than 5 tonnes $\mathrm{CO}_{2}$ equivalents (before 2015 the limit was $3 \mathrm{~kg} \mathrm{~F}$-gas).

\section{Record-keeping and reporting}

The mandatory record keeping required for stationary plants according to the EU F-gas regulations, also applies to Swedish flagged ships. Every ship-owner operating a refrigeration plant containing more than 14 tons $\mathrm{CO}_{2}$ equivalents (before 2015 the limit was $10 \mathrm{~kg} \mathrm{F-gas)} \mathrm{are} \mathrm{obliged} \mathrm{to} \mathrm{send} \mathrm{in} \mathrm{a} \mathrm{yearly} \mathrm{report} \mathrm{to} \mathrm{the} \mathrm{Swedish} \mathrm{Transport} \mathrm{Agency.}$ This report shall include, for example, quantity and type of F-gas installed, results from the periodic leak tests, quantity of F-gas added during installation, maintenance or when repairing a leak, and quantity of any F-gas recovered (SFS, 2016).

\section{Certification}

The EU F-gas regulations regarding certification and training also apply to Swedish flagged ships, with a few exceptions. The Swedish regulation requires that if, during sea passage, there are to be performed any installations, re-builds, repairs or other interventions in the $\mathrm{AC} /$ refrigeration equipment there must be at least one crew member holding an F-gas certificate. A shipping company is not required to hold a company certificate as long as the maintenance, service or leak checks are only performed on the shipping company's own ships (SFS, 2016).

\subsubsection{Naval registers}

As discussed above, neither the GWP of the refrigerants, nor the leakage of HFC refrigerant, is constrained by globally mandatory requirements for marine applications. However, some naval registers propose voluntary class notations for refrigeration systems having low environmental impact. Most of the Swedish/Nordic flagged vessels are classified according to DNV-GL or Lloyds register, which class notations are presented next. 
DNV-GL offers two environmental class notations: "Clean" and "Clean Design" (DNV$\mathrm{GL}$, 2017a).

Notation "Clean": For refrigeration systems having more than $10 \mathrm{~kg}$ initial charge the refrigerant may be HFCs or natural refrigerants such as $\mathrm{NH}_{3}$ and $\mathrm{CO}_{2}$. Annual leakage shall not be more than $10 \%$ of the total refrigerant charge for each system. The leakage shall be documented.

Notation "Clean design": Refrigerants used shall either be a natural refrigerant or an HFC with GWP of maximum 2000.

Worth mentioning is that in DNVs regulations dated 2015 the concept of "Total Equivalent Warming Impact (TEWI)" was introduced; "As an alternative to GWP $\leq 2,000$ a documented equivalent TEWI may be accepted". However, according to correspondence with DNV, during the merging of DNV and GL rules, there were doubts whether the TEWI is a validated alternative to the GWP limit, since input parameters are not clear. Therefore, the acceptance of TEWI is removed in DNV GL rules.

Lloyd's Register proposes the ECO class notation which limits the GWP of the HFC refrigerant to a maximum of 1,950 . The frequency of leak detection and the maximum allowable annual leakage rate is dependent of the charge of each system according to Table 3. Records are to be maintained demonstrating that leak testing is carried out in accordance with the periodicity by qualified personnel holding relevant certification (Lloyd's Register, 2017).

Table 3: Periodicity of leak test and max leakage rates according to Lloyds ECO class notation

\begin{tabular}{lrr} 
Charge of F-gas & Periodicity of leak tests & Max leakage rate \\
& & \\
$<3 \mathrm{~kg}$ & 6 months & $10 \%$ \\
$3-30 \mathrm{~kg}$ & 3 months & $10 \%$ \\
$30-300 \mathrm{~kg}$ & Monthly & $5 \%$ \\
$>300 \mathrm{~kg}$ & Monthly & $<3 \%$ \\
\hline
\end{tabular}

There is also an option of achieving a supplementary "environmental friendly character"; for refrigeration systems - character $R$. To achieve this, natural substances are to be used as the refrigerants in all main refrigeration systems such as cargo systems, provision rooms and $A C$. Small factory-built refrigeration system(s) that use F-gases having a GWP $<1,950$ are allowable.

\subsubsection{Regulations for firefighting substances}

IMO: Fire-fighting medium containing ozone depleting substances such as Halon 1301, which was the traditionally used media for fixed fire-fighting systems on board ships, are prohibited in new installations since 1994 on board all ships (IMO, 2017). IMO considers that the shore-based regulations on Halons will govern the phasing out of existing installations, as the availability of Halons decreases. IMO has thus not defined any target date for the phasing out of Halons and the phase out of Halon is consequently an issue for each Flag State (DNV, 2011). 
EU: The phase out of Halon for EU flagged ships (including NOR/NIS vessels) are the most notable program (Gielle Marine, 2017). Until 31.12.2002, existing Halon fire extinguishing systems could be used and re-filled/topped up with re-cycled Halon until 31.12.2002. After this date any re-filling or use of Halon as a fire-extinguishing medium are prohibited (DNV, 2011).

Except from IMO and EU regulations there are additional notes from Classification Societies and recommendations from the National Maritime Administrations.

Naval register's: Lloyds register does not permit the use of halocarbons as the fireextinguishing medium in fixed fire-fighting systems. No further requirements are included in the ECO class notation (Lloyd's Register, 2017).

To achieve DNV-GLs class notation "Clean" or "Clean Design" the substances used in fixed firefighting systems shall either be natural substances or substances having a GWP of less than 4,000 or 2,000 respectively. Examples of natural substances are argon, nitrogen, water spray, high expansion foam and $\mathrm{CO}_{2}$ (DNV-GL, 2017a).

Nordic regulations/recommendations: According to companies working with installations of fixed firefighting systems on board ships, the regulations in the Nordic countries are about the same even if the different Maritime Administrations/Agencies can have different "recommendations". For example, the Swedish Transport administration has approved the use of Halotron IIB ${ }^{2}$ but states that if "Clean Agent FS 49 C2 (Halotron IIB) is installed the employees should be informed that it might be dangerous to be occupied in the space at the release or leakage of the gas and should therefore be considered as a $\mathrm{CO}_{2}$ system regarding personal safety aspects. (Transportstyrelsen, 2014). A person holding an F-gas certificate must perform the service of these systems, and for new installations the company must be certified. (Svensk Brand- och Säkerhetscertifiering $A B$, 2017).

In the Faroe Islands, the use of halons has been banned since 2014 .

${ }^{2}$ Halotron IIB is a mixture of $60-80 \%$ R $134 a, 10-30 \%$ R 125 and $10-30 \%$ R744. 


\section{Substitute refrigerants}

$\mathrm{R} 22\left(\mathrm{CHClF}_{2}\right)$ has been widely used as a working fluid in many refrigeration units in Europe until the ratification of EC Ozone Regulation (EC/2037/2000). This regulation prohibited the use since 2001 in new systems due to its ozone depletion properties and to meet the goals under the Montreal Protocol. The term "use" involves servicing and maintenance and it is still legal to operate an existing system provided it does not need to be recharged. R22 is still chosen in new systems and retrofitting projects on a global scale outside the EU. In Europe usage of most fluorinated gasses are soon restricted in the future, due to the quotas described in the EU F-gas regulation, and will therefore in time be phased out. Consequently, suitable substitutes must be found which are practically feasible and within the EU F-gas regulation restrictions. The following list describes different groups of currently available working fluids, which are replacements for R22 or represent fluids applied in marine HVAC\&R systems.

\subsection{Saturated hydrofluorocarbons}

Saturated hydrofluorocarbons do have a relatively long atmospheric lifetime and a corresponding high global warming potential:

- $\mathrm{R} 134 \mathrm{a}\left(\mathrm{CF}_{3} \mathrm{CH}_{2} \mathrm{~F}\right)$ : This saturated $\mathrm{HFC}$ refrigerant is property wise comparable to $\mathrm{R} 22$ and is widely used as an alternative in medium temperature refrigeration systems. It has a GWP of 1,430;

- $\mathrm{R}_{32}\left(\mathrm{CH}_{2} \mathrm{~F}_{2}\right)$ : Property wise very similar to R134a. Mainly applied in AC units and for blends. Due to the relatively low GWP of 675 it is being used more and more. $\mathrm{R}_{32}$ is flammable and classified in safety group ${ }^{3} \mathrm{~A}_{2} \mathrm{~L}_{\text {; }}$

- $\mathrm{R} 152 \mathrm{~A}\left(\mathrm{CHF}_{2} \mathrm{CH}_{3}\right)$ : Property wise very similar to R134a. It is mainly applied for blends; however, it is being used more now mostly due to the low GWP of 124. It is flammable and classified in safety group $\mathrm{A}_{2}$;

- HFC blends:

- $\mathrm{R}_{4} 04 \mathrm{~A}\left(\mathrm{CF}_{3} \mathrm{CH}_{3} / \mathrm{CF}_{3} \mathrm{CHF}_{2} / \mathrm{CF}_{3} \mathrm{CH}_{2} \mathrm{~F} ; \mathrm{GWP}=3,922\right) ;$

- $\mathrm{R} 507\left(\mathrm{CF}_{3} \mathrm{CH}_{3} / \mathrm{CF}_{3} \mathrm{CHF}_{2} ; \mathrm{GWP}=3,985\right)$;

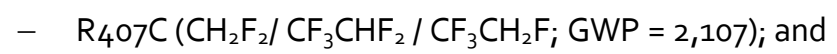

\footnotetext{
3 ASHRAE Standard 34 "Designation and Safety Classification of Refrigerants" identifies in total 6 mandatory and 2 optional safety groups of refrigerants depending on their toxicity (Class $A$ to $B$ ) and flammability (Class 1 to 3 ). $A_{2} L$ and $B_{2} L$ are so called lower flammability refrigerants with a maximum burning velocity of $<10 \mathrm{~cm} / \mathrm{s}$.
} 
- $\mathrm{R}_{410 \mathrm{~A}}\left(\mathrm{CH}_{2} \mathrm{~F}_{2} / \mathrm{CF}_{3} \mathrm{CHF}_{2} ; \mathrm{GWP}=2,088\right)$ are widely used. These are the common refrigerant substitutes for old HCFC plants when converted to eliminate ozone depletion. All of them do have a high GWP value, which limits their usage in the future.

\subsection{Unsaturated hydrofluorocarbons}

Unsaturated hydrofluorocarbons, also called Hydrofluoroolefins (HFOs) represent another kind of HFCs, which are potential replacements for HCFCs and saturated HFCs, especially in AC units. In general, unsaturated hydrofluorocarbons react more rapidly with $\mathrm{OH}$ radicals and their atmospheric lifetimes are significantly shorter compared to traditional HFCs. Due to their short lifetime, they do have lower global warming potentials than saturated hydrofluorocarbons.

- $\mathrm{R} 1234 \mathrm{yf}\left(\mathrm{CF}_{3} \mathrm{CF}=\mathrm{CH}_{2} ; \mathrm{GWP}=4\right)$ : This unsaturated $\mathrm{HFC}$ refrigerant has a chemical double bond and is a so-called hydrofluoroolefin (HFO). Its GWP value is low since atmospheric lifetime is very short ( $\sim 11$ days) and the double bond is reacting with $\mathrm{OH}$ radicals present in the ambient air. R1234yf is so-called mildly flammable and classified in the newly developed safety group $\mathrm{A}_{2} \mathrm{~L}$. The auto-ignition temperature is $405^{\circ} \mathrm{C}_{\text {. }} \mathrm{CF}_{3} \mathrm{C}(\mathrm{O}) \mathrm{F}$ is the major atmospheric oxidation product of $\mathrm{R} 1234 \mathrm{yf}$. The atmospheric fate of $\mathrm{CF}_{3} \mathrm{C}(\mathrm{O}) \mathrm{F}$ is hydrolysis, which occurs on a time scale of approximately 10 days, to give $\mathrm{CF}_{3} \mathrm{C}(\mathrm{O}) \mathrm{OH}$ (trifluoroacetic acid $=\mathrm{TFA}$ ) and HF (hydrogen fluoride):

- The acidity of TFA is approximately 34,000 times stronger than that of acetic acid4. TFA is harmful when inhaled, causes severe skin burns and is toxic for water organisms even at low concentrations. TLV (Threshold Limit Value $\left.^{5}\right)=5 \mathrm{ppm}$; IDLH (Immediately dangerous to life or health $)=30 \mathrm{ppm}$;

- Upon contact with moisture, including tissue, HF immediately converts to hydrofluoric acid, which is highly corrosive and toxic, and requires immediate medical attention upon exposure. Breathing in hydrogen fluoride at high levels or in combination with skin contact can cause death from an irregular heartbeat or from fluid build-up in the lungs. TLV (Threshold Limit Value $)=3$ ppm; IDLH (Immediately dangerous to life or health $\left.{ }^{6}\right)=30 \mathrm{ppm}$.

The threshold limit value (TLV) of R1234yf is 200 ppm in Germany.

\footnotetext{
${ }_{4}^{4}$ Acetic acid is the main component of vinegar apart from water.

$5 T L V$ : the level to which a worker can be exposed day after day for a working lifetime without adverse effects. ${ }^{6} I D L H$ is defined by the US National Institute for Occupational Safety and Health (NIOSH) as exposure to airborne contaminants that is "likely to cause death or immediate or delayed permanent adverse health effects or prevent escape from such an environment". The applied maximum short exposure tolerance period is $30 \mathrm{~min}$.
} 
- R1234ze(E) $\left(\mathrm{CF}_{3} \mathrm{CH}=\mathrm{CHF}_{;} \mathrm{GWP}=7\right)$ : This unsaturated $\mathrm{HFC}$ refrigerant has a chemical double bond. Exhibits flame limits at temperatures in excess of $28^{\circ} \mathrm{C}$. The auto-ignition temperature is $368^{\circ} \mathrm{C}$. When $\mathrm{CF}_{3} \mathrm{CH}=\mathrm{CHF}$ is reacting with $\mathrm{OH}$ radicals present in the ambient, due to partial oxidation, both $\mathrm{HC}(\mathrm{O}) \mathrm{F}$ and $\mathrm{CF}_{3} \mathrm{CHO}$ are formed (Javadi et al. 2008):

- $\mathrm{HC}(\mathrm{O}) \mathrm{F}$ (Formyl fluoride): decomposes autocatalytically near room temperature to carbon monoxide (CO) and hydrogen fluoride (HF);

- $\mathrm{CF}_{3} \mathrm{CHO}\left(2,2,2\right.$-Trifluoroethanal): $\mathrm{CF}_{3} \mathrm{CHO}$ is also called Fluoral7, $\mathrm{CAS}$ No. 75-90-1.

- $\mathrm{R} 513 \mathrm{~A}\left(\mathrm{CF}_{3} \mathrm{CF}=\mathrm{CH}_{2} / \mathrm{CF}_{3} \mathrm{CH}_{2} \mathrm{~F}_{;} \mathrm{GWP}=631\right) \& \mathrm{R} 450 \mathrm{~A}\left(\mathrm{CF}_{3} \mathrm{CH}=\mathrm{CHF} / \mathrm{CF}_{3} \mathrm{CH}_{2} \mathrm{~F}_{;} \mathrm{GWP}=\right.$ $605 \mathrm{~kg}$ ) are blends of the $\mathrm{R} 1234 \mathrm{yf}$ and $\mathrm{R} 1234 \mathrm{Ze}(\mathrm{E})$ with $\mathrm{R} 134 \mathrm{a}$. These refrigerants still exhibit non-flammable characteristic like R134a and are classified in the safety group $A 1$ as long as it is inside the system. However, decomposition of the fluids takes place as described for the single fluids when released into the ambient air.

\subsection{Natural working fluids}

Natural working fluids do have favourable thermodynamic and fluid properties enabling energy efficient refrigeration system configurations. In addition, their environmental impact is well known, and safety standards are established:

- $\mathrm{R} 717$ (ammonia, $\mathrm{NH}_{3 i} \mathrm{GWP}=0$ ): $\mathrm{R} 717$ has been used as a refrigerant during the last 140 years and is still widely used, especially for large industrial plants for food processing. It has neither a global warming potential nor does it deplete the Ozone layer. R717 will not be restricted under the $\mathrm{F}$ gas regulation. R717 has very high latent heat and the refrigeration capacity per unit mass flow is the highest of all refrigerants used in traditional vapour compression systems. Because R717 has low molar mass it can have much higher particle velocity than all other refrigerants and therefore small pipe sizes can be used. It is important to avoid copper components, because R717 and water will corrode copper, zinc and their alloys. For example, R717 and water will destroy the copper windings of the electrical motor in a hermetic compressor. It is flammable and toxic; therefore, it is classified in safety group $B_{2} L$ and does require extra safety measures, similar to the HFOs described above. TLV $=50 \mathrm{ppm}$. IDLH $=300 \mathrm{ppm}$. It is necessary that the R717 refrigeration system is situated in a separate room, that personnel is well trained and has appropriate safety equipment available; 
- $\mathrm{R} 744$ (carbon dioxide $\mathrm{CO}_{2} ; \mathrm{GWP}=1$ ): $\mathrm{R} 744$ is a working fluid in refrigeration systems since the late 19th century. It disappeared from marine applications in the 1950's mainly due to technical difficulties and the introduction of synthetic working fluids, operating at lower working pressures. These technical difficulties are solved nowadays and there is a wide range of applications where $\mathrm{R} 744$ is the preferred working fluid (freezing applications, commercial refrigeration, hot water heat pumps, mobile AC, etc.).

R744 is the only non-flammable working fluid classified as A1. R744 is non-toxicity and will not be restricted under the $\mathrm{F}$-gas regulation. Independent of the concentration of oxygen in the air, the human lung needs to reject $\mathrm{R} 744$ into the atmosphere; therefor the TLV is $5.000 \mathrm{ppm}$. The IDLH threshold for R744 is 40,000 ppm.

- R29o (propane, $\mathrm{C}_{3} \mathrm{H}_{8} ; \mathrm{GWP}=3$ ): Propane is an example of another group of natural working fluids, the hydrocarbons. It has a very low GWP. Systems with R29o have been in operation globally for many years. It is widely used within compact systems with low charges such as home refrigeration systems. There are no charge limitations if these kinds of units are located outdoors in restricted areas. The major disadvantage is the high flammability and classified as safety group $A_{3}$.

Figure 19 shows the GWP values of the mainly applied working fluids, their safety classification and indicates to which group they belong.

Figure 19: GWP values of working fluids

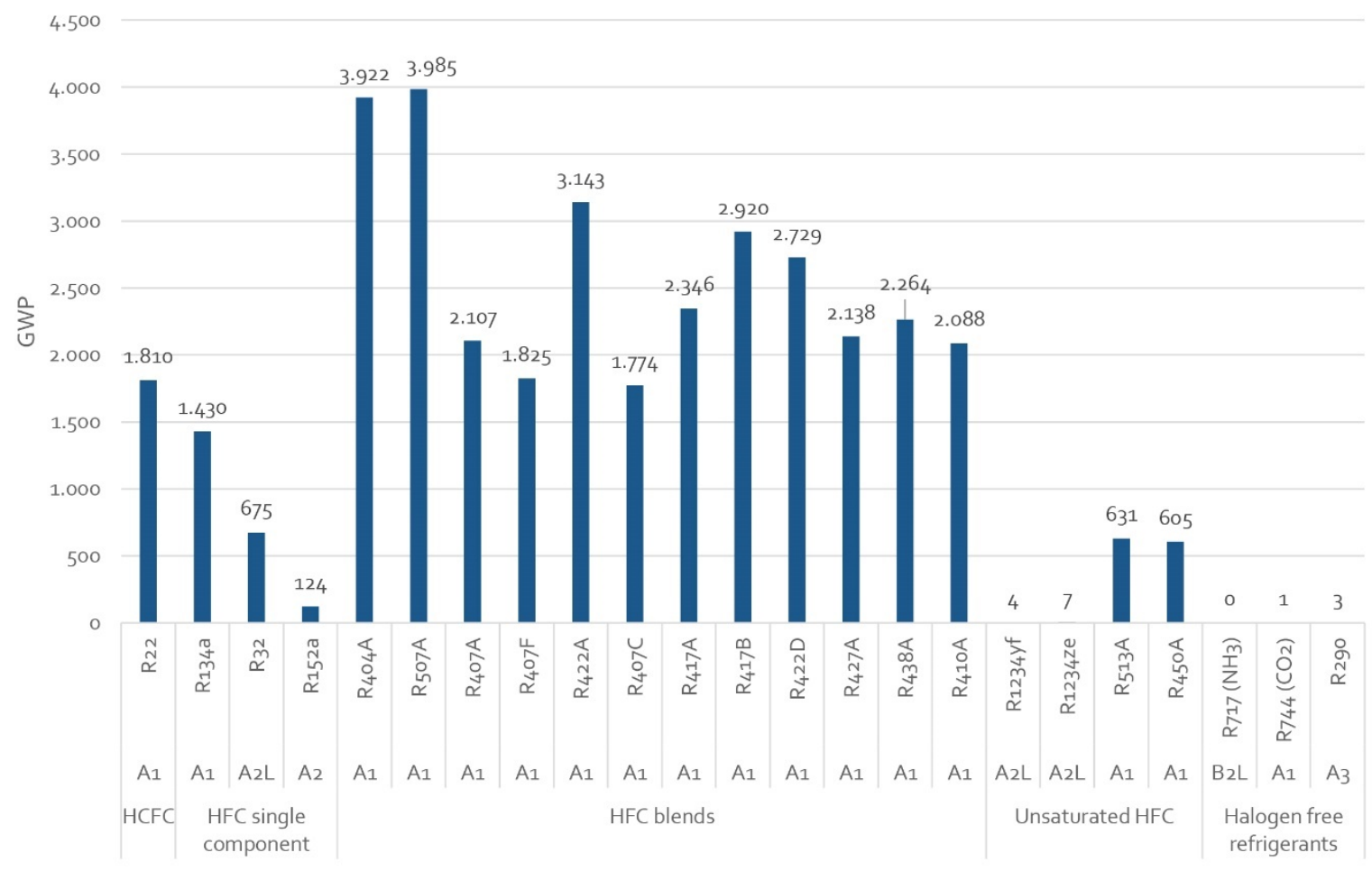




\subsection{Safety considerations}

Flammability studies of refrigerant are always made without the presents of lubricant (oil). Very few refrigeration systems are oil-free. In case of a leakage and the presence of oil, most of the refrigerant-oil mixtures are flammable. In case of HCFCs and HFCs toxic decomposition products will occur, if these substances are exposed to fire or hot surfaces.

Federal German authority for physical and chemical tests of materials and facilities (BAM) have investigated combustion reactions with R1234yf. ${ }^{8}$ Carbonyl difluoride $\left(\mathrm{COF}_{2}\right)$ developed in the case of fire, at rather high concentrations of 10,000 ppm (lethal effect of $\mathrm{COF}_{2}$ for humans is only $1 \mathrm{ppm}$ at an exposure of 10 minutes). Carbonyl difluoride is the fluorine analogue of phosgene, the substance used as a poison gas in some wars. Fluorine phosgene (= carbonyl difluoride) can therefore be assumed to have a similar effect. A remaining question for the experts from BAM is whether $\mathrm{COF}_{2}$ is present long enough in case of a car accident - or at all if sufficient water is present in the ambient air - to cause a health hazard to people present in the accident scenarios to be considered.

In marine applications, availability of firefighting water should not be a problem, however, the main toxic decomposition product in case of a fire including any HFC refrigerant of the HVAC\&R systems is hydrogen fluoride (HF).

\subsubsection{Safety and retrofit}

The newly introduced $A_{2} L$ refrigerants should not be applied to retrofit existing refrigeration systems according to the recommendations of the British Refrigeration Association and FETA. (British Refrigeration Association Action Group (2018), Feta 2018). These reports strongly advice to perform full risk assessments in any case and to implement the required modifications.

\subsection{How to analyse environmental impact}

Within the scope of this report only a few studies were found dealing with the performance of low-GWP refrigerants in other marine applications than refrigeration plants on fishing vessels and refrigerated containers.

Below two TEWI-analyses of provision plants on passenger/cruise ships are summarised. The results from these studies are presented as a comparison to using R407F as refrigerant.

Frejd and Himmelman (2017) performed a theoretical comparison of different refrigerants for a provision freezing plant on a passenger ship, currently using $\mathrm{R}_{4} \mathrm{O}_{4} \mathrm{~A}$ as refrigerant. The low-GWP refrigerants investigated were the non-flammable

\footnotetext{
${ }^{8}$ https://www.bam.de/_SharedDocs/DE/Downloads/Jahresbericht2014.pdf?_blob=publicationFile\&v=5 (Page 96-98).
} 
unsaturated HFC zeotropic mixtures $\mathrm{R}_{442} \mathrm{~A}, \mathrm{R} 448 \mathrm{~A}$ and $\mathrm{R} 449 \mathrm{~A}$, the flammable unsaturated HFC zeotropic mixtures R454A and R455A (containing also R744), as well as R717 (ammonia).

Compared to $\mathrm{R}_{407 \mathrm{~F}}$ all the alternative refrigerants resulted in a lower energy efficiency for the plant. The decrease in COP was between 9 and $14 \%$, the lowest decrease happens when using R448A (see Figure 20, left, below).

However, looking at the Total Equivalent Warming Impact (TEWI), with an assumed annual leakage rate of $13 \%$ and 10 years lifetime, R717 and the two flammable short-life HFC mixtures (R454A and R455A) performed the best, due to their low GWP (see Figure 20, right).

Figure 20: Drop in energy efficiency compared to $\mathrm{R}_{4} 07 \mathrm{~F}$ (left). Direct and indirect $\mathrm{CO}_{2}$ emissions (kg) (right)

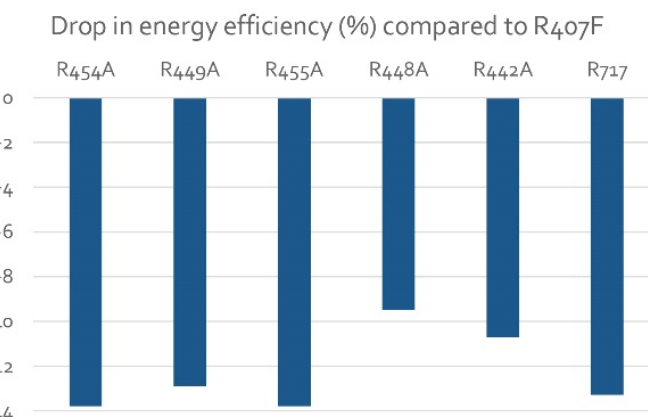

$\mathrm{CO}_{2}$ emissions $(\mathrm{kg})$

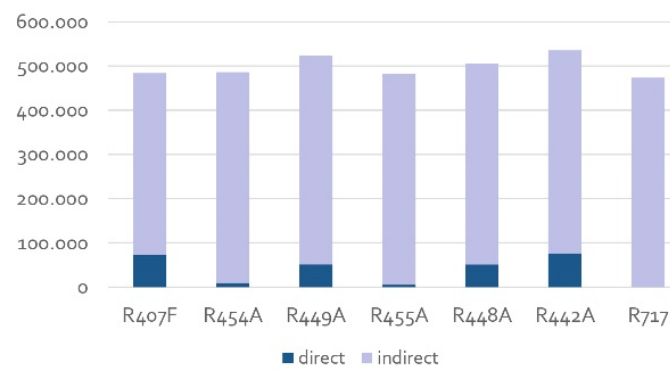

It was also concluded that for this plant, the direct GHG emissions (due to refrigerant leakage) were around $10-20 \%$ of the total $\mathrm{CO}_{2}$ emissions, meaning that the energy efficiency is very important for reducing the carbon footprint of the plant.

However, this study did not investigate $\mathrm{R} 744\left(\mathrm{CO}_{2}\right)$ as a potential alternative, despite the global trend to apply $\mathrm{R} 744$ in commercial refrigeration applications. Provisions plants and commercial refrigeration systems do have similar specifications and requirements.

Pigani et al. (2016) compared theoretically a number of low-GWP refrigerants (R1234Yz, R1234ef, $\mathrm{NH}_{3}$, simple R744) with $\mathrm{R}_{407 \mathrm{~F}}$ for a provision cooling/freezing plant. The reference plant with $\mathrm{R}_{407} \mathrm{~F}$ consists of an indirect chilling and a direct freezing system.

A number of different system layouts were compared. The Simple system consists of one chilling plant with either of the fluids, and one freezing plant with R744. A large reduction in system COP at the design point was found, since an unrealistic R744 baseline circuit was applied in the theoretical study.

However, by doing system modifications, a much better result was achieved. For example, operating the freezing- and chilling plant in a cascade configuration and including an economiser in the chilling plant results in a higher system COP for all fluids. Integrating the system with the HVAC system (chilled water applied as heat sink) also results in a better system performance.

Pigani et al. (2016) concludes that the most important element determining system efficiencies is the plant configuration, and not the use of different refrigerants. However, the volumetric capacity mainly depends on the refrigerant selected, and the 
volumetric capacity for carbon dioxide is very high, making it a good alternative when space is limited. The direct emissions (refrigerant leakage) amount to less than $10 \%$ of the total emissions for the current refrigeration plant using $\mathrm{R}_{407 \mathrm{~F}}$, while less than $1 \%$ for the low GWP alternatives.

As pointed out by Pigani et al. (2016), and as also seen in the study by Frejd and Himmelman (2017), most of the GHG emissions of marine refrigeration plants are indirect, thus the emissions are related to the production of electricity, which most often is done by diesel generators. However, with a change in the fuel used on board, the introduction of waste heat recovery systems and the use of on-shore electricity, the indirect emissions can be reduced in the future.

Shortcoming of the study of Pigani et al. (2016); the comparison included neither the latest $\mathrm{R} 744$ refrigeration technology nor did it adapt the boundary conditions which are important for transcritical R744 systems. Since the revival of R744 as working fluid (Lorentzen 1993) it has been pointed out that many theoretical comparisons between conventional systems and transcritical R744 systems are lacking the know-how of how real R744 systems behave:

- The approach temperature: the outlet temperature of supercritical R744 from the gascooler is typically $1-2$ Kelvin above the ambient- or seawater temperature (see also Chapter 6);

- The pressure drop in R744 refrigerant lines does not affect the performance of systems as much as it does for low-pressure fluids, and since it is mainly neglected, the advantage for R744 systems is not implemented;

- Evaporators in modern R744 systems do zero superheat, due to that and high heat transfer coefficients this results in much higher evaporation temperatures compared to traditional HFC systems.

\subsubsection{Recommendation to estimate the environmental impact of the HVAC\&R units}

Total Equivalent Warming Impact (TEWI) as shown above is an established method within the refrigeration sector. TEWI measures the global warming impact of a HVAC\&R system by quantifying the amount of greenhouse gasses a unit emits. TEWI does not account for the energy embodied in product materials, greenhouse gas emissions from chemical manufacturing and end of life disposal of the unit.

Therefore, a life cycle climate performance (LCCP) approach should be established for marine refrigeration applications, too. LCCP is well established for commercial HVAC\&R units and mobile air conditioning units. This transparent method describing the environmental impact of systems allows an evaluation of alternative systems. LCCP can also account for minor emission sources that are not accounted for in TEWI such as transportation leakage, manufacturing leakage and refrigerant manufacturing emissions. LCCP is calculated as the sum of direct and indirect emissions generated over the lifetime of the refrigeration system. Direct emissions include all effects from 
the release of refrigerants into the atmosphere. This includes annual leakage and leakage during the disposal of the unit. The indirect emissions include emissions from the manufacturing process, energy consumption during operation and disposal of the system. LCCP allows to describe the environmental impact of the HVAC\&R units based on transparent input parameters like system performance data at various load conditions and heat rejection temperatures (sea water temperature).

\subsection{Summary of refrigerant substitutes}

The preferred refrigerant to substitute $\mathrm{R} 22$ in marine vessels should have:

- long term prospective;

- well-known and understood environmental impact;

- enable an energy efficient operation of the units within the limited space available on marine vessels;

- highest possible safety class.

This means that it should not be restricted under the F-gas regulation. Therefore, none of the HFC blends mentioned above is a suitable choice. The safety classification is also of critical importance when the refrigeration systems are intended to be a part of mobile applications, e.g. marine vessels. Therefore, the use of R152A, R290, R1234yf and R1234zeE are unlikely and only possible when thorough risk analysis and mitigations have been made. The group of blends like $\mathrm{R}_{513} \mathrm{~A}$ and $\mathrm{R}_{45} \mathrm{OA}$ might have potential in medium temperature applications due to the relatively low GWP and $A 1$ safety classification, however, as indicated in the safety data sheet of the fluid suppliers, the "hazardous decomposition products may include: Hydrogen fluoride, Carbon oxides, Fluorinated hydrocarbons, Carbonyl fluoride". Another problem is the complex chemical blend and composition, the global availability, and the higher GWP relative to $\mathrm{R} 744$ that makes these non-natural working fluids less economical.

Ammonia is an approved natural working fluid also for maritime refrigeration systems. The system architectures for R717 units are understood, challenges with suction pressures below atmospheric pressure at low evaporation temperatures $\left(>-33,5^{\circ} \mathrm{C}\right)$ are known, while handling safety issues (classified as B2) is standard. Previously R744 equipment was not available in the capacity range required for fishing vessels. This leaves $\mathrm{CO}_{2}(R 744)$ as the most promising choice for maritime refrigeration applications globally, where $R 717$ cannot be applied. 


\section{Examples of refrigeration systems on different types of vessels}

\subsection{State of the art}

\subsubsection{Fishing vessels}

Many fishing vessels have traditionally used R22 in their refrigeration-systems, but since 2015 it is forbidden to refill units within Europe. In Norway, there has been a change towards RSW systems applying natural refrigerants.

Correspondence with refrigeration vendors has shown that all new installations have R717 or R744 for the RSW systems. Several old R22 systems have been replaced with $\mathrm{R} 717$ systems. Since 2012, there are also systems with R744 in the field.

Inquiries have shown that it is still possible to refill recycled R22, even though it is forbidden. On the other side, it is possible to retrofit $\mathrm{R} 22$ systems with a refrigerant with no ozone depletion potential, for example R134a, R404A and R507A, however, these fluids do still have a high global warming potential and will be restricted in the future by the F-gas regulation from EU. These refrigerants will also be phased out within a few years (Bitzer 2014a,b). In the past, the investment costs for HFC systems have been lower than for similar system with natural refrigerants. However, R717 is more energy efficient and therefore the operating costs and the secondary emissions from energy use are much lower. The cost of new non-natural refrigerants is also very high in countries that follow the F-gas regulation and have high GWP related taxes on these media, such as Norway and Spain.

Unsaturated HFCs and their blends, as described in Chapter 3.2, tend to have a high flammability risk (Bitzer 2014b), i.e. a simple retrofit is no option if the risk assessments are made properly.

$\mathrm{R} 717, \mathrm{R} 717 / \mathrm{R} 744$ and all R744 systems are common for newly built refrigeration systems on board fishing vessels in the Nordic region. The system layout for R717 units does not differ very much form traditional 222 units.

Figure 21 shows the simplified system circuit of the $\mathrm{R} 744 / \mathrm{R} 717$ cascade unit installed in MS Kvannøy ${ }^{9}$ (trawler), as shown in Figure 22 and Figure 23. 
Figure 21: $\mathrm{R} 744 / \mathrm{NH}_{3}$ system circuit as installed in the trawler MS Kvannøy

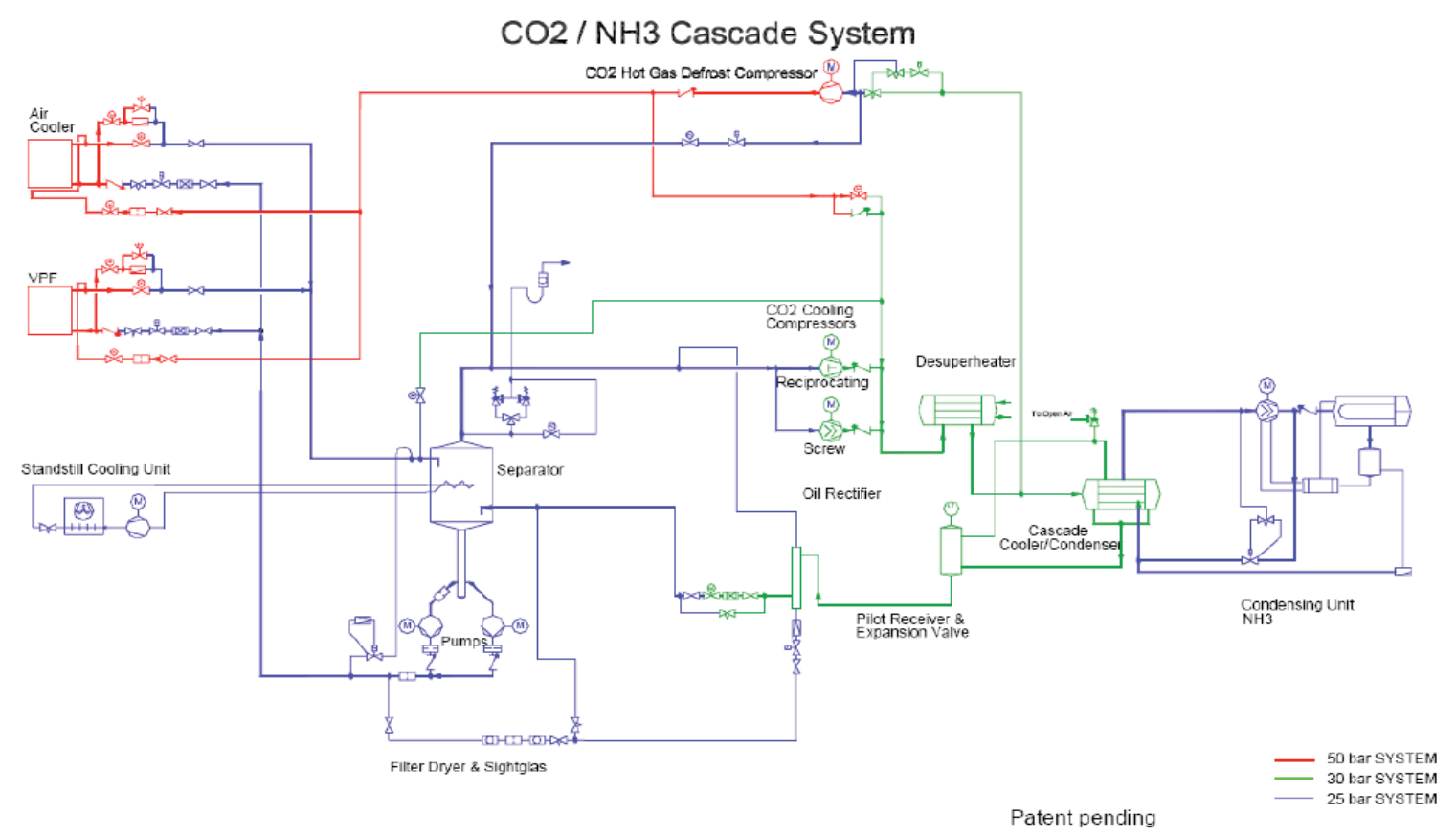

The $\mathrm{R} 744$ and $\mathrm{R} 717$ refrigeration system consists of 11 plate freezers and has an installed cooling (freezing) capacity of $1,350 \mathrm{~kW}$ at $-48^{\circ} \mathrm{C}$. In addition to the plate freezers there are 9 refrigerated sea water tanks. Due to the fluid properties of R744 and the lower achievable evaporating temperature inside the freezers, a $40 \%$ reduction in product freezing time (compared to $\mathrm{R} 22$ system at $-40^{\circ} \mathrm{C}$ ) is achieved.

Figure 22: $\mathrm{R} 744 / \mathrm{NH}_{3}$ system installed in the machine room of MS Kvannøy

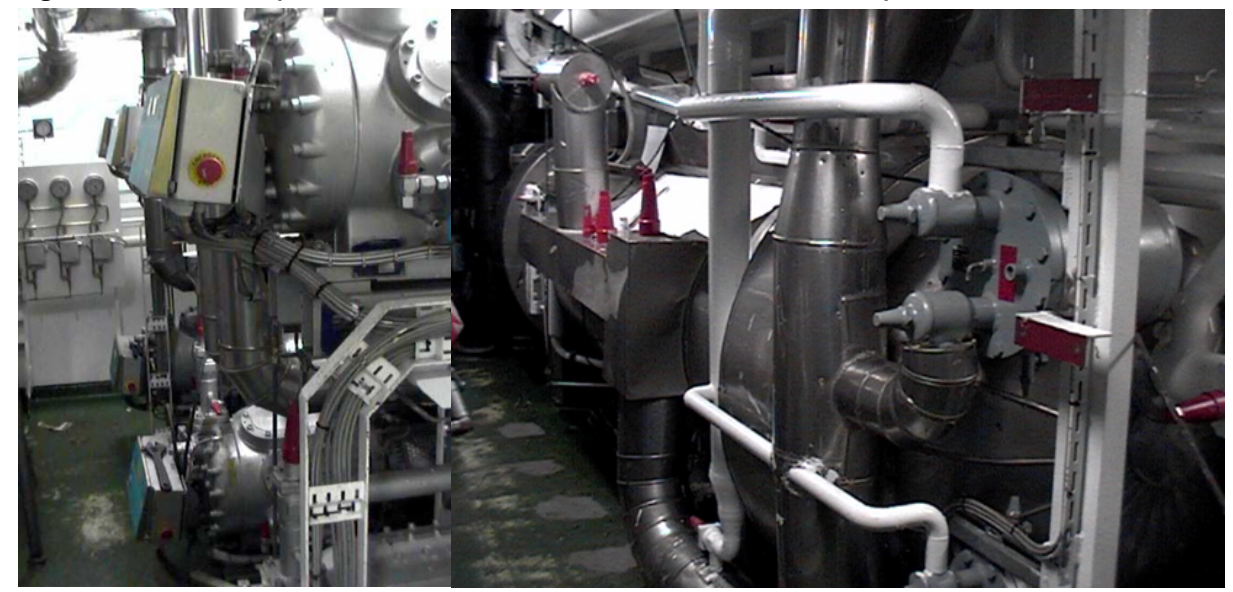

Source: Johnson Controls. 


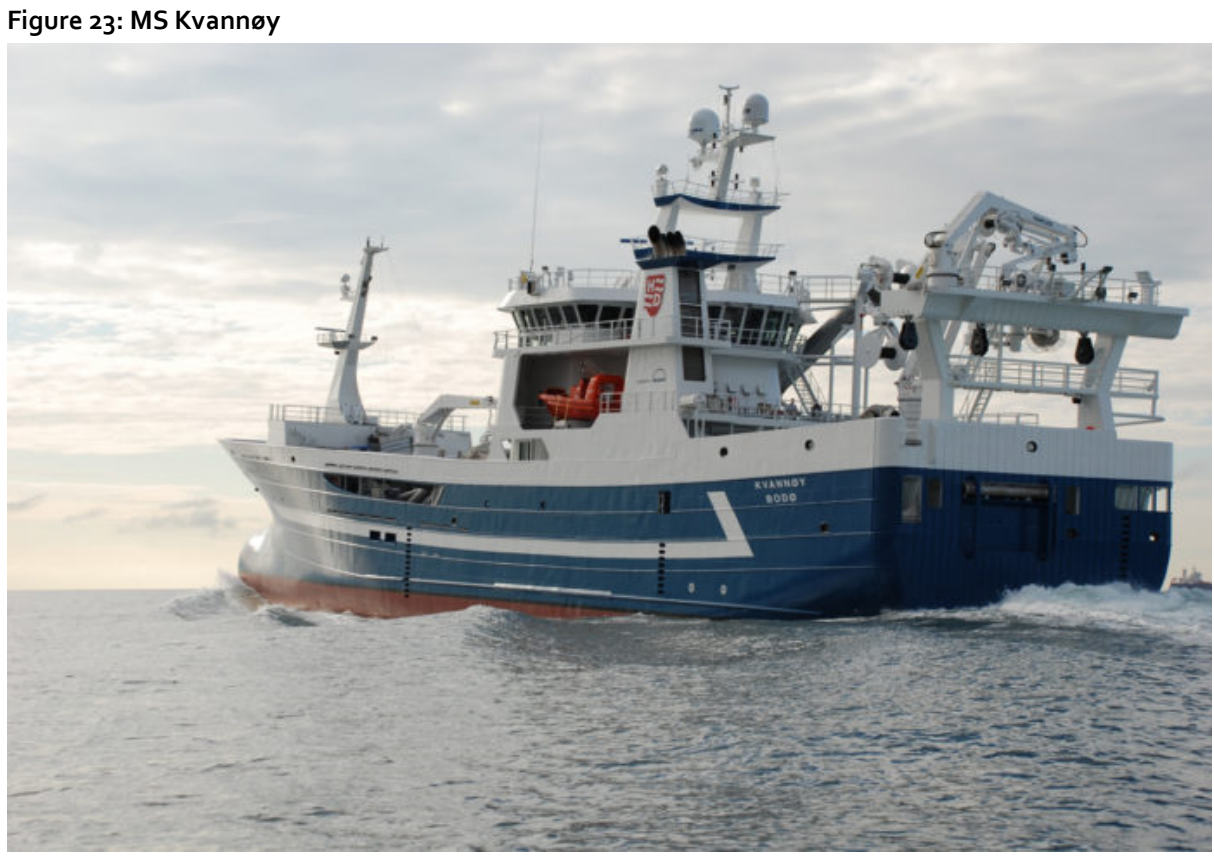

Polar Amarog is a trawler built in 2004 and currently sailing under the flag of Greenland. Polar Amarog has an $\mathrm{R} 717 / \mathrm{R} 744\left(\mathrm{NH}_{3} / \mathrm{R} 744\right)$ cascade freezing system for 180 metric ton of fish/day in vertical plate freezers. Consisting of two R717 screw compressors, four R744 reciprocating compressors and two R717 screw compressors for refrigerated sea water (RSW) storage tanks (see Figure 24).

Figure 24: $\mathrm{R} 744 / \mathrm{NH}_{3}$ system (vertical plate freezers on the left hand side) installed in the machine room of Polar Amarog

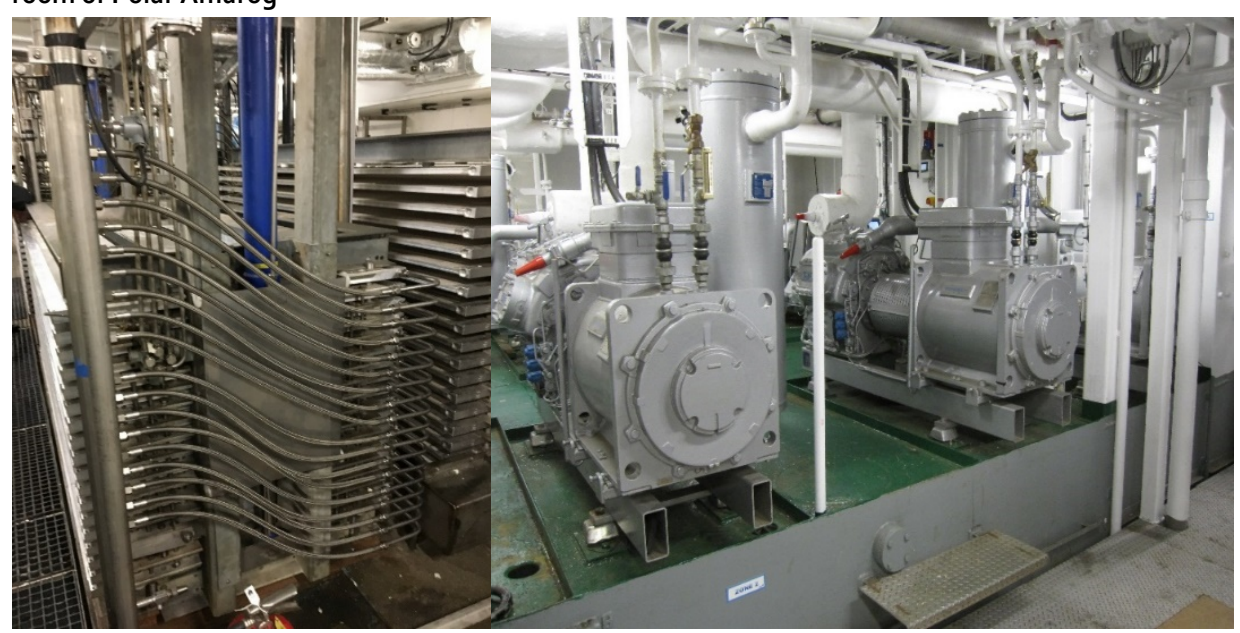

Source: Johnson Controls/Sabroe. 
Polar Princess was elongated with an 18-meter section in 2015. The R22 freezing system was exchanged with a $\mathrm{R} 717 / \mathrm{R}_{744}\left(\mathrm{NH}_{3} / \mathrm{R}_{744}\right)$ cascade freezing system for 200 metric ton/day in 12 vertical DSI plate freezer and a R717 RSW refrigeration system for refrigerated sea water (RSW) storage tanks. The $\mathrm{NH}_{3} / \mathrm{R} 744$ freezing system consists of $3 \times \mathrm{R} 717$ screw compressors and $5 \times \mathrm{R} 744$ reciprocating piston compressors (see Figure 25). Commissioning of the system took place in June 2015 .

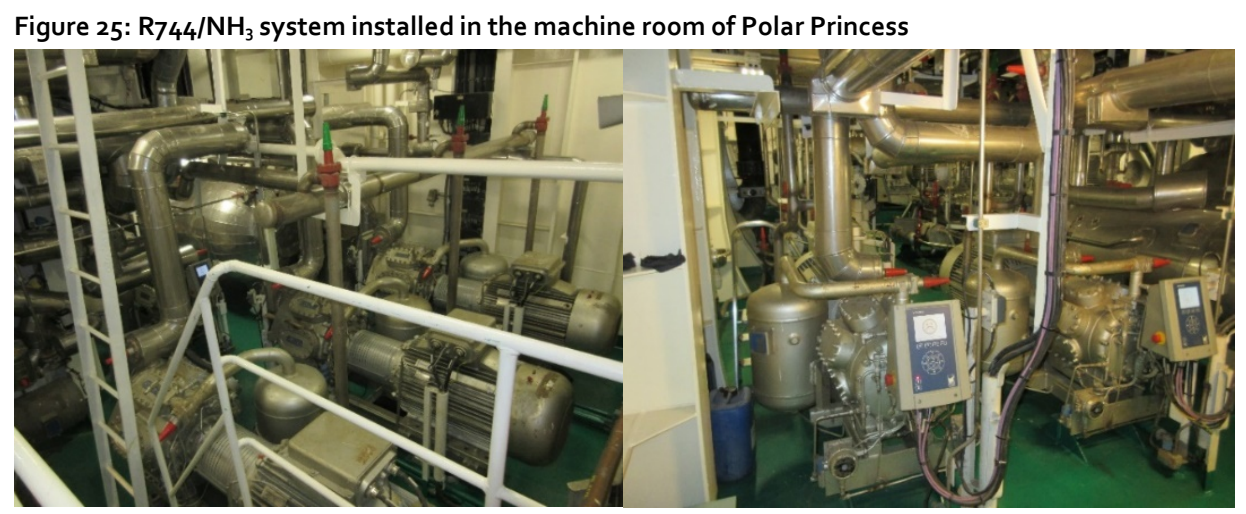

Source: Johnson Controls.

Mekanik Sergey Agapov. Figure 26 shows a JCl R717/R744 cascade freezing system (2014) on the 115-meter Russian pelagic trawler Mekanik Sergey Agapov with an installed freezing capacity of 240 metric ton/day in vertical plate freezers. Containing three R717 screw compressors, six R744 reciprocating compressors and one R717 screw compressors dedicated for the RSW system. 
Figure 26: $\mathrm{R} 744 / \mathrm{NH}_{3}$ system installed in the machine room of pelagic trawler Mekanik Sergey Agapov

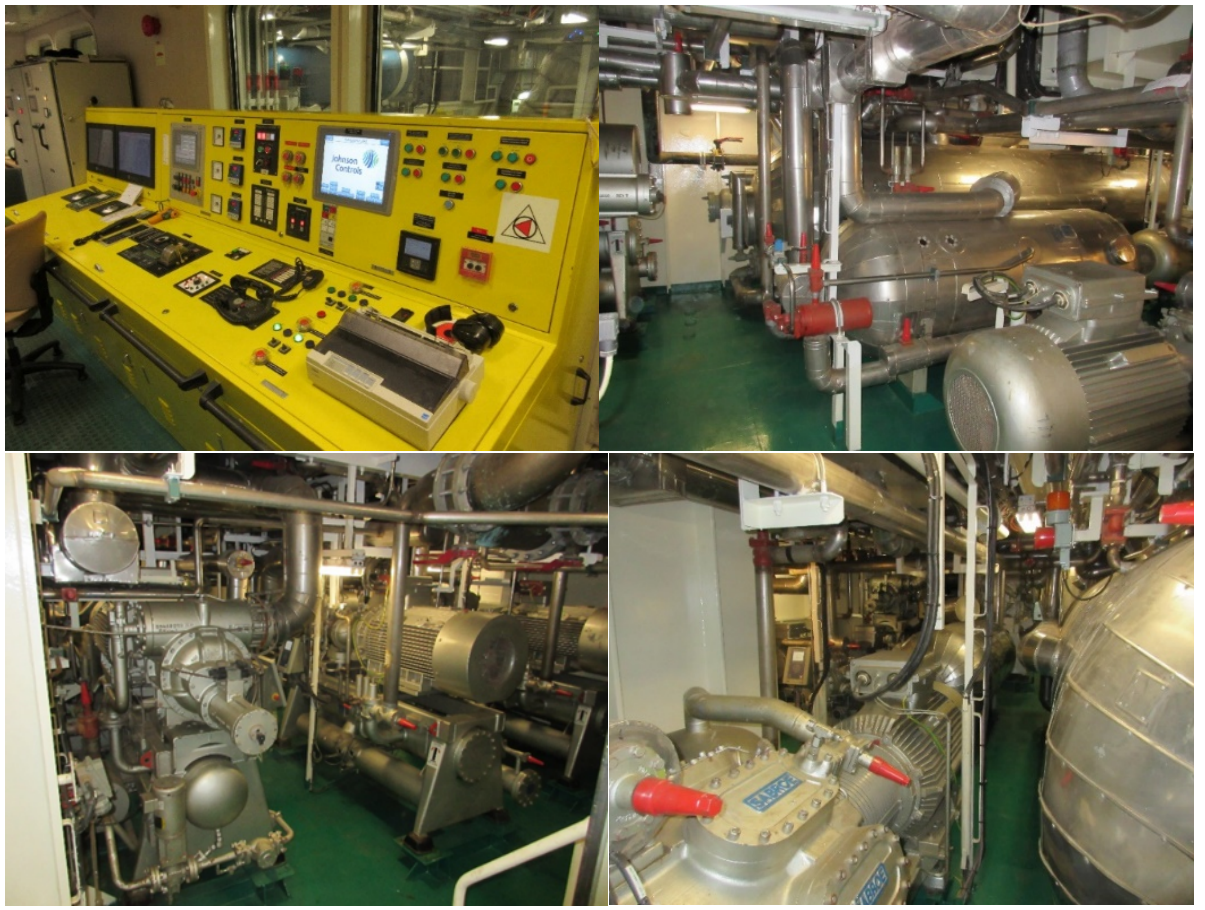

Source: Johnson Controls/Sabroe.

MS Roaldnes ${ }^{10}$, as shown in Figure 27 is an example of a Stern Trawler. The previous R22 system has been replaced by an all R744 refrigeration system by Kuldeteknisk AS.

Figure 27: M/T Roaldnes

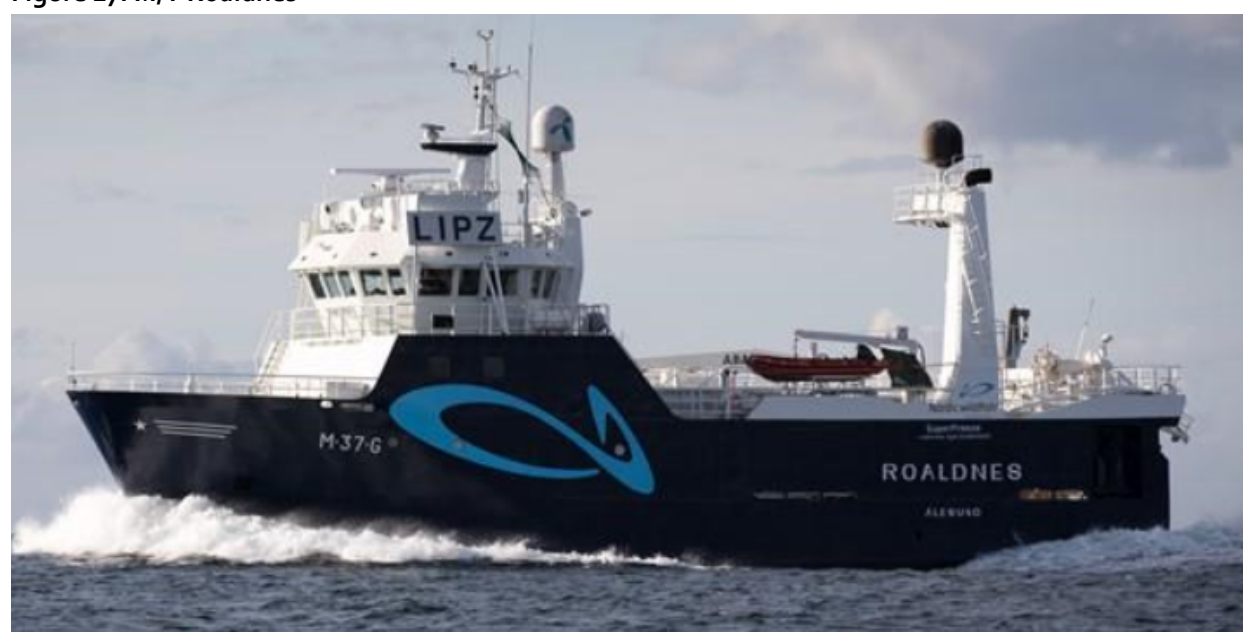

${ }^{10}$ M/T Roaldnes: 34 meter long, 10 meter wide. Trawling: haddock \& pollock; Capacity 120 metric tonnes. 
As shown in Figure 28 , the $\mathrm{R} 744$ refrigeration system was located at the same location as the previous R22 system.

Figure 28: Pictures of the Previous R22 unit (left hand side) and the R744 unit (right hand side) inside the machine room of $M / T$ Roaldnes
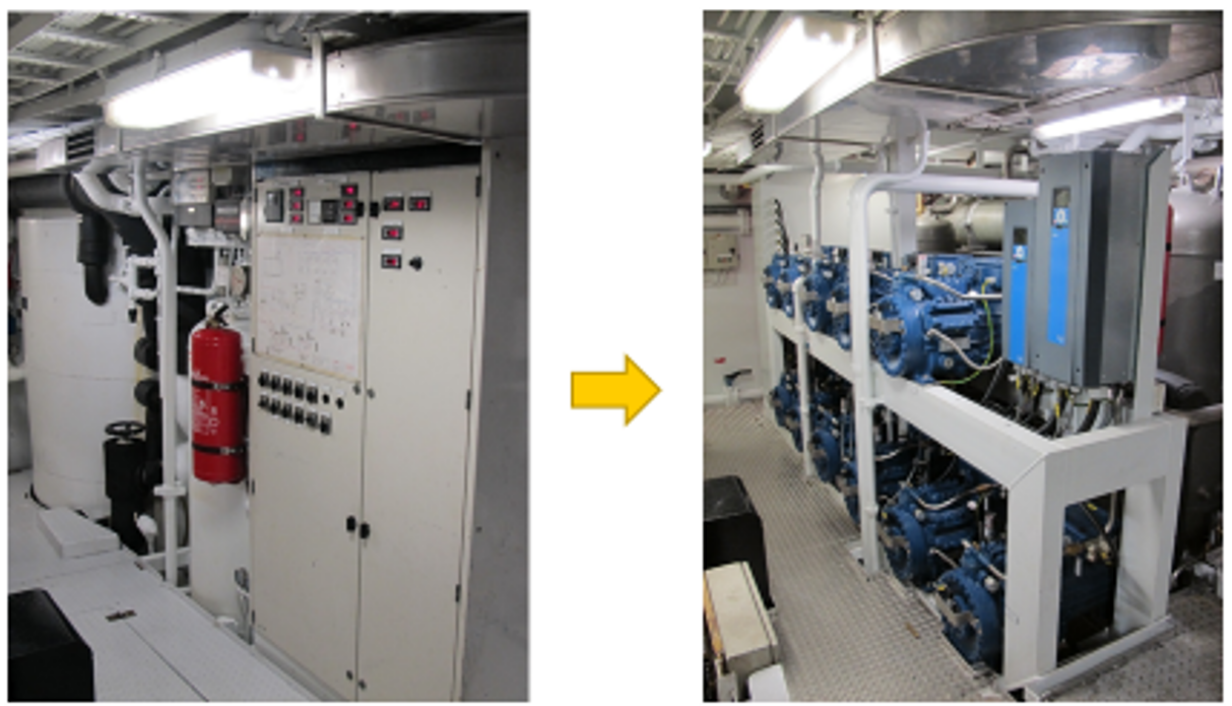

Source: Kuldeteknisk AS.

The conversion of the refrigeration system resulted in an increase capacity for the freezing of the fish from 30 metric ton/day to 40 metric ton/day when applying the R744 refrigeration system. Due to the lower achievable evaporation temperature inside the plate freezers, the average freezing time was reduced from $190 \mathrm{~min}$ to $140 \mathrm{~min}$. The defrost time of the R744 unit was also faster compared to the previous R22 unit.

The main conclusion after the conversion from $R_{22}$ to $R 744$ was:

- deep-freezing time is reduced by $25 \%$;

- R744 unit requires less space on board:

- Allows to apply smaller piping;

- Approximately $20 \%$ less space for the refrigeration unit;

- Less freezers required for same freezing capacity.

- R744 plate freezers achieve better food quality according to customers;

- better and easier service of the unit.

The latest development of low temperature R744 refrigeration technology is shown in Figure $29\left(500 \mathrm{~kW}\right.$ of cooling capacity at $\left.-50^{\circ} \mathrm{C}\right)$. As can be seen on the right hand side, the installed number of the reciprocating compressors is high, due the limited availability of large capacity R744 compressors, see also Chapter 6 . 


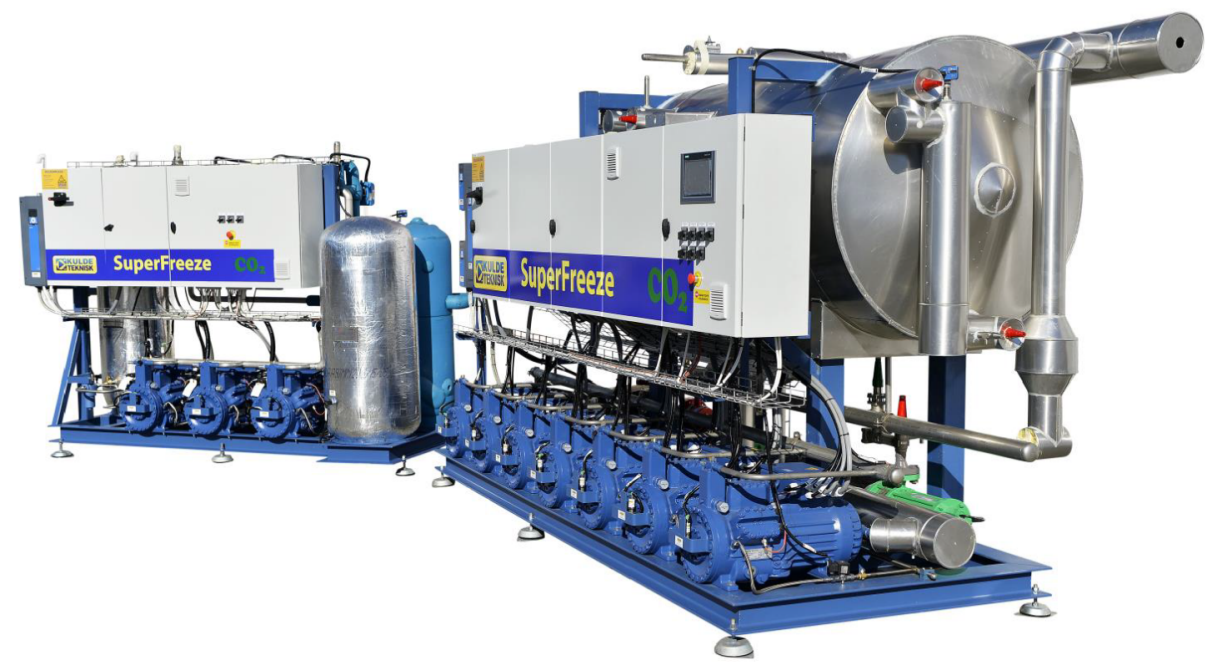

Source: Kuldeteknisk AS.

Beside freezing applications, refrigerated seawater (RSW) storage tanks and refrigeration units are required on most fishing vessels. Figure 30 shows a compact seawater cooled R744 RSW refrigeration unit. Currently these units are delivered with up to $500 \mathrm{~kW}$ cooling capacity to cool down sea water from $8^{\circ} \mathrm{C}$ to temperatures close to the freezing point of water.

Figure 30: Compact seawater cooled R744 RSW refrigeration unit

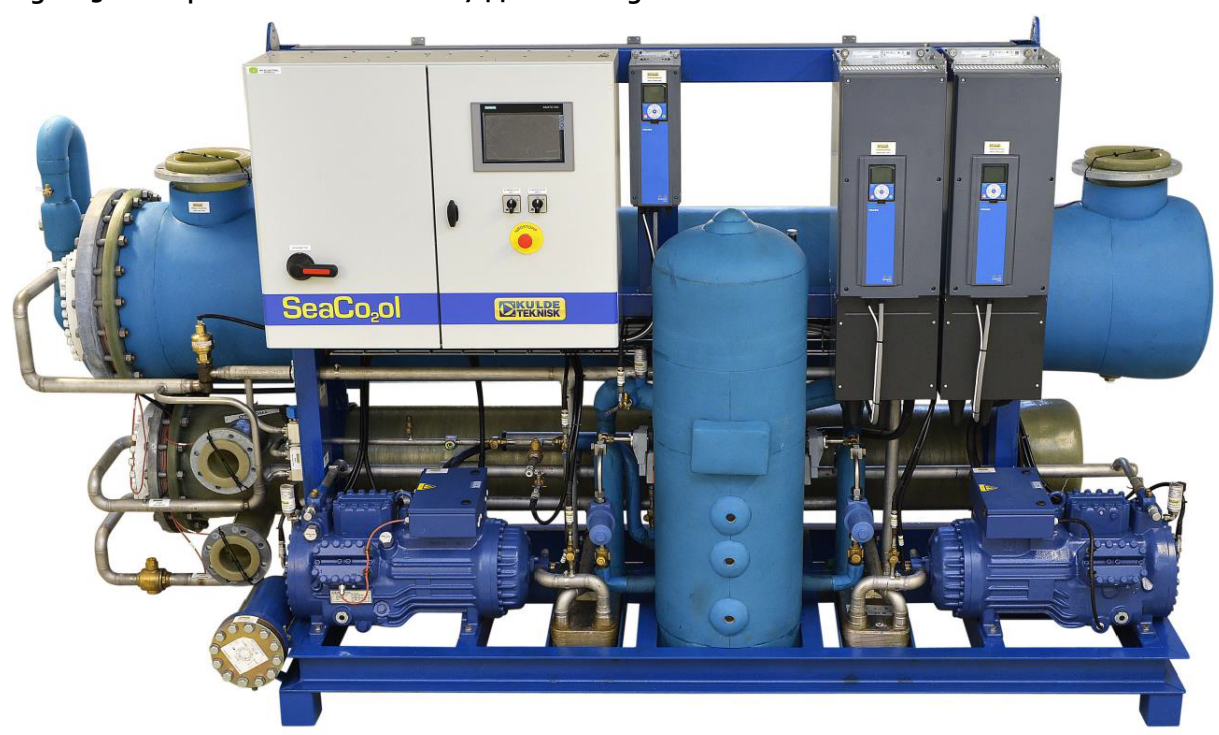

Source: Kuldeteknisk AS. 


\subsubsection{Passenger vessels}

Air conditioning: According to the survey presented in 2.2 (refrigerant reports from Swedish ships) the standard AC systems in larger passenger ships today are indirect systems with circulation of chilled water. The use of indirect system provides a saving of up to $50 \%$ of refrigerant charge, compared to direct expansion systems, and it also reduces the refrigerant leakage rates. In some of the smaller passenger ships, direct systems are still used, however, often divided in a number of smaller units to reduce the refrigerant pipe length, and thus the refrigerant charge and leakage risk.

In Figure 31 an example of a typical AC system equipped with a screw compressor, with the following design conditions, is shown:

- Chiller water temperature: inlet $12^{\circ} \mathrm{C} /$ outlet $7^{\circ} \mathrm{C}_{i}$

- Refrigerant: R407C/R134a;

- Cooling media: Fresh Water $36^{\circ} \mathrm{C}$ or Sea Water $32^{\circ} \mathrm{C}$;

- Condensing temperature: $43 / 40^{\circ} \mathrm{C}$ (Fresh Water/Sea Water).

Figure 31: Example of AC system

\section{SINGLE SYSTEM}

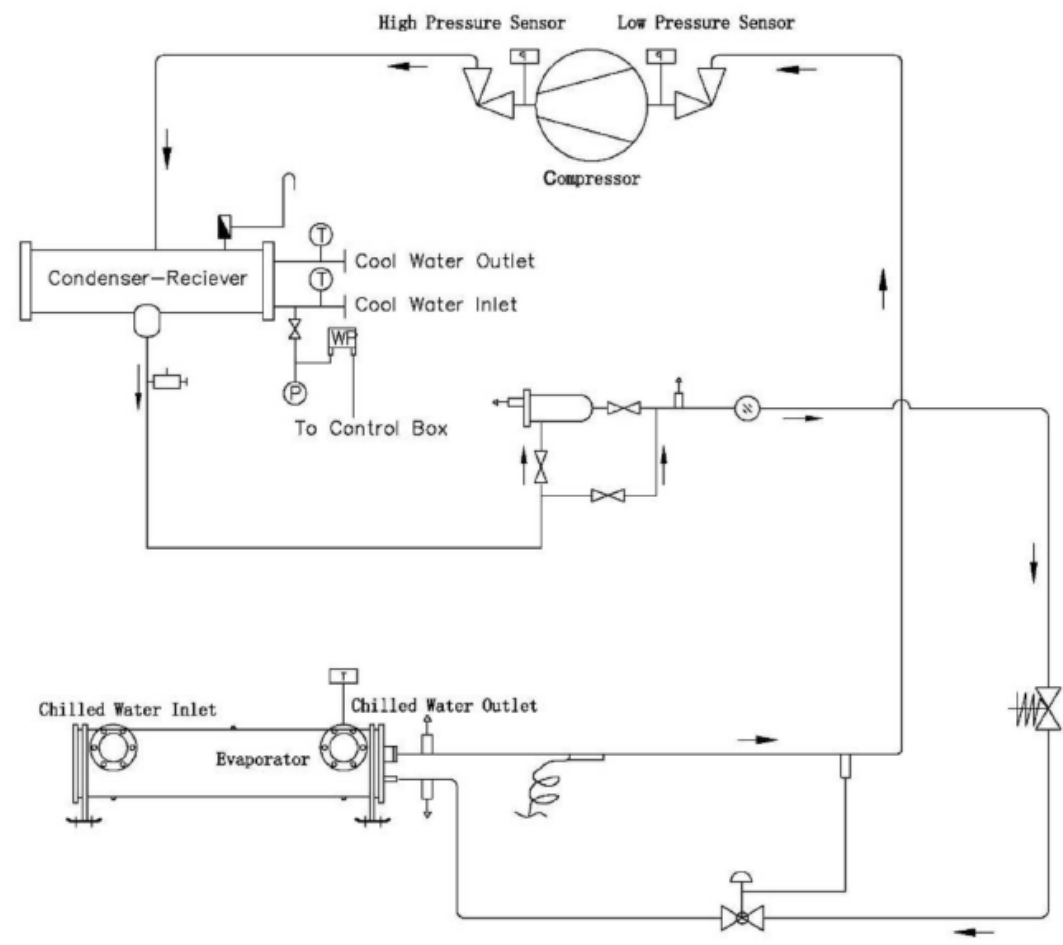

Source: JL Marine \& Engineering, 2017.

According to correspondence with refrigeration companies, almost all new installations on passenger ships are indirect systems, producing chilled water of around $6-10^{\circ} \mathrm{C}$. The most commonly used refrigerant is still $\mathrm{R}_{134 a}$ (in some installations $\mathrm{R}_{407} \mathrm{C}$ is used). For 
example, Carrier marine \& offshore (2017) offers large R134a AC chillers (up to 10.5 MW) with a variable speed centrifugal compressor, enabling high efficiency also at part-load, and a refrigerant leakage rate of less than $0.1 \%$.

The use of indirect AC systems with chilled water circulation also enables the use of "free-cooling" or pre-cooling during parts of the year when the sea water is cold enough. There are a few Swedish passenger ships that apply this concept.

Provision refrigeration: The provision refrigeration is most often a direct system. Traditionally these systems contain only one compressor and one condenser, coupled to different evaporators for the different storage rooms. By instead having separate systems for freezing and cooling the energy efficiency can be increased, and different refrigerants can be chosen for either the freezing or the chilling application. Among the Swedish passenger vessels that sent in a refrigerant report for 2016 about 50\% used separate systems for their provision cooling and freezing plant. However, it is only one of these ships that use different refrigerants (R404A for freezing, and R407C for cooling).

In Figure 32 an example of a traditional system installed on a passenger ship is shown, with a refrigerant charge of $30 \mathrm{~kg} \mathrm{R} 404 \mathrm{~A}$, and a cooling capacity of only $15 \mathrm{~kW}$. The plant is designed to maintain the following temperatures:

Figure 32: Traditional provision refrigeration system

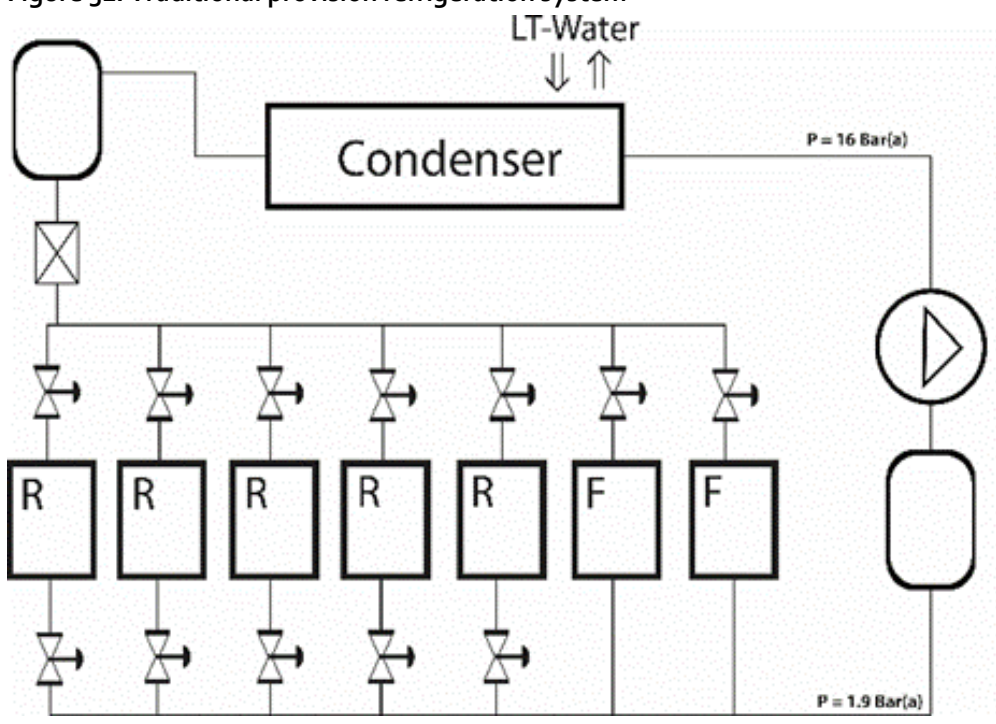

Note: Fish room: $-25^{\circ} \mathrm{C}$. Freezer room: $-25^{\circ} \mathrm{C}$. Beverage room: $+4^{\circ} \mathrm{C}$. Dairy room: $+4^{\circ} \mathrm{C}$. Meat room: $+4^{\circ} \mathrm{C}$. Vegetable room: $+6^{\circ} \mathrm{C}$. Dry store: $+10^{\circ} \mathrm{C}$.

Source: Frejd and Himmelmann, 2017.

The site design conditions are as follows:

- Outside temperature: $+45^{\circ} \mathrm{C}$;

- Ambient inside temp: $+25^{\circ} \mathrm{C}_{i}$

- Fresh water (LT water) temp: $+36^{\circ} \mathrm{C}_{i}$

- Sea water temp: $+32^{\circ} \mathrm{C}$. 
In Figure 33 a similar provision refrigeration system, offered today is shown. The system is designed for $38^{\circ} \mathrm{C}$ cooling media temperature (fresh water from the engine cooling system), and $-25^{\circ} \mathrm{C}$ freeze temperature using $\mathrm{R}_{407} \mathrm{~F}$ as refrigerant (Teknotherm, 2017a).

Figure 33: Provision refrigeration plant

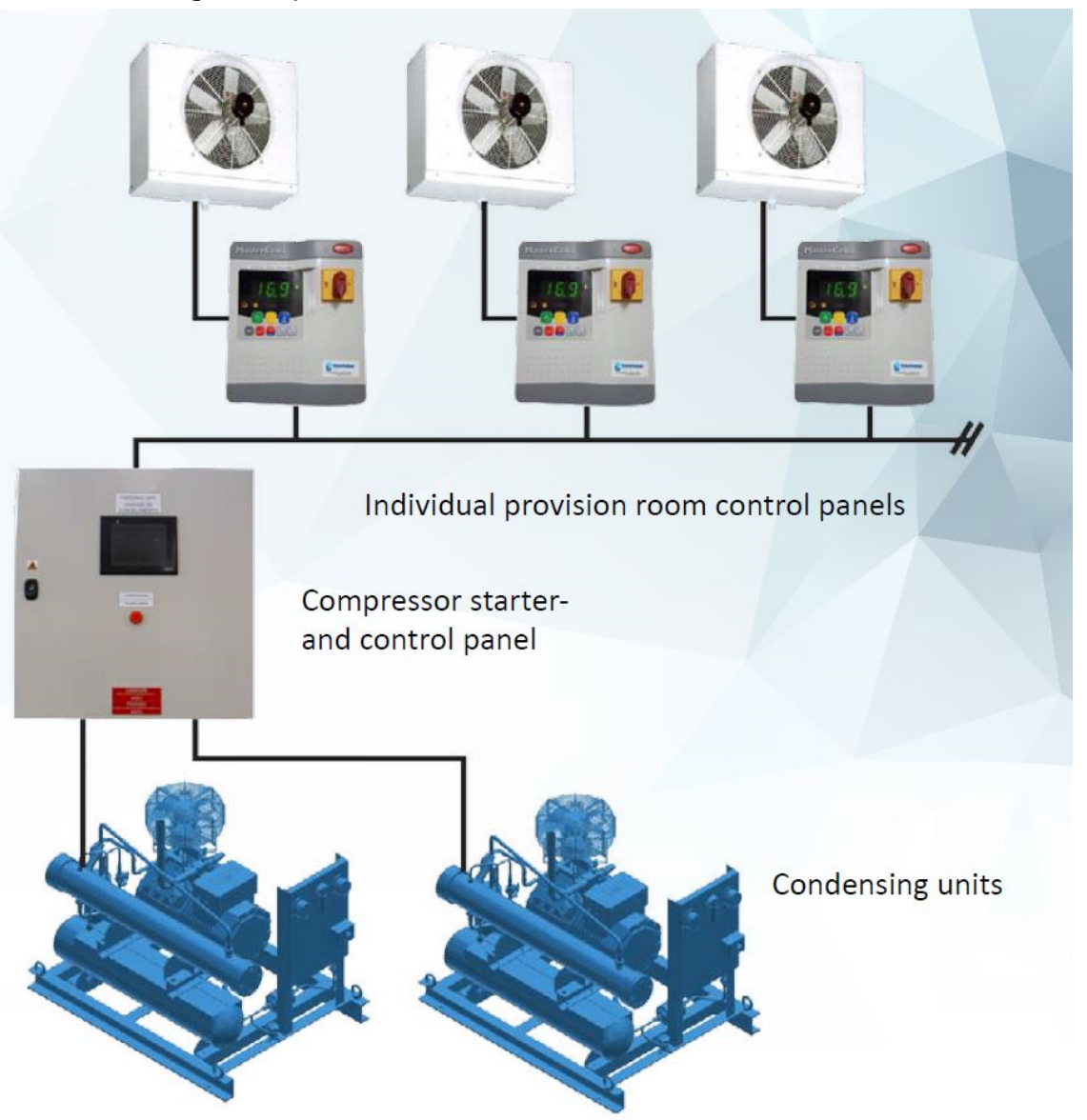

Source: Teknotherm, 2017a.

According to Johnson Controls most new installations today, on cruise and passenger ships, have separate compressors for the cooling and freezing plant. R134a is often used in the cooling system, while $\mathrm{R}_{407} \mathrm{C}$ or $\mathrm{R}_{407 \mathrm{~F}}$ is used in the freezing system. According to correspondence with other refrigeration unit companies, $\mathrm{R}_{407} \mathrm{~F}$ is today the most recommended refrigerant for provision refrigeration, even if some still offers

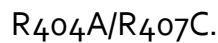

However, one of the top selling OEMs for R744 compressor racks in Europe reports that leading cruise ship owners have started to purchase $\mathrm{R} 744$ refrigeration racks (e.g. $2 \times 400 \mathrm{~kW}$ of cooling capacity for chilled food and $2 \times 100 \mathrm{~kW}$ for frozen food) for their new cruise ships (4-5,000 passengers class). In addition, offers for replacing existing HFC units with R744 units from current cruise ships have been made. 


\subsubsection{Cargo vessels}

Air conditioning: Traditionally, the standard air conditioning system in cargo ships is a split system with direct evaporation. The condenser, which is usually cooled by sea water (up to $32^{\circ} \mathrm{C}$ ), and the compressor are placed near the engine room and the generator. The evaporator is placed near to the living area of the crew, connected by refrigerant lines that could be of considerable length.

However, according to the survey presented in 2.2 many of the ships have an AC system divided in smaller aggregates, in order to decrease the refrigerant pipe length, and thus the refrigerant charge and risk for leakages. For example, many of the large RoRo-ships (vehicle carriers) have separated AC systems for crew cabins, bridge, engine control room and engine workshop. In Table 4 below an example from a vehicle carrier is presented.

Table 4: Examples of separated AC systems

AC Unit

$\mathrm{kg} \mathrm{R}_{407 \mathrm{C}}$

Crew cabin FWD

Crew cabin AFT

Bridge PS

Bridge SB

Main Switch

Engine Control

Engine Work

Engine Change room

Today, indirect AC systems also for cargo ships are offered. For example, on a newly built Faroese tanker vessel the $A C$ system is a chilled water system using $\mathrm{R}_{407} \mathrm{C}$ as refrigerant, which according to the shipping company's chief inspector has reduced the leakage rate and the energy consumption and is also more reliable.

Provision refrigeration: The provision refrigeration on a cargo ship is a direct system. Most often the freezing and cooling plant use the same compressor and condenser. Of the cargo ships included in the survey presented in 2.2 there are a few with separate systems for freezing and cooling, but the same refrigerant is still used in the two systems.

\subsubsection{Other applications for HFCs on board}

In addition to $\mathrm{AC}$ and provision refrigeration, there are some other applications for systems using F-gases (HFCs) on board Nordic marine vessels.

Refrigerated storage of $\mathrm{CO}_{2}$ : Some ships (for example vehicle carriers) have a $\mathrm{CO}_{2}$ fire smothering system installed on board to protect the machinery and cargo spaces. Pressurized and refrigerated $\mathrm{CO}_{2}$ liquid is stored in insulated tanks fitted with a refrigeration system, most often using $\mathrm{R}_{4} \mathrm{O}_{4} \mathrm{~A}$ as refrigerant with an average charge of $28 \mathrm{~kg}$ per unit. 
Organic Rankine Cycle (ORC): In order to increase the ship's total energy efficiency there are today a number of waste heat recovery solutions, such as ORC, available on the market. The first marine ORC system installation, in 2011, was a result of the cooperation of a Swedish company (Opcon) and a Swedish shipping company (Wallenius) with the support of the Swedish Energy Agency. The ORC uses waste heat from the main engine's cooling water, producing up to $500 \mathrm{~kW}$ electric energy, which means an energy saving of around $5 \%$ (Opcon, 2015). Since this energy would otherwise have been produced by fuel oil the ORC installation reduces the emissions of $\mathrm{CO}_{2}, \mathrm{NO}_{x}$ and $\mathrm{SO}_{\times}$. However, the installed amount of working fluid is $1,900 \mathrm{~kg} \mathrm{R} 236 \mathrm{fa}$, having a GWP of 9,800 .

Fixed firefighting systems: Traditionally Halon-1301 (with ODP $=10$ and $G W P=7,240$ ) has been used in fixed firefighting systems in the ship's machinery room. IMO and EU has prohibited new Halon installations since 2005 and 2003, respectively (Gielle Marine, 2017). According to companies working with installations of fixed firefighting systems on board ships the most commonly used media is $\mathrm{CO}_{2}$, but there are also systems using HFCs available for marine installations; Halotron II and FEM200, of which Halotron is the most commonly used on merchant ships. Halotron IIB, which is a blend consisting of R134a, R125 and R744, is primarily distributed in Sweden, Finland and US (Halotron.com, 2017). FM-200 (HFC-227ea) is more commonly used on leisure boats, and according to international standards the gas is approved for use in occupied spaces (Kidde Sweden, 2017).

There are also some other F-gases available as firefighting media; FE25 (HFC-125), $\mathrm{FE}_{3} 6$ (HFC-236fa) and FE13 (HFC-23), with GWP values of 3,500, 9,810 and 11,700 respectively. However, according to the companies contacted in this study, these are not used on board ships.

\subsection{Alternative system solutions (on the market/under development)}

\subsubsection{Fishing vessels}

\section{R717 systems}

A test system was described by Widell and Ladam (2013). It was an R717 system with low refrigerant charge, developed by MMC Havyard. It had a cooling capacity of $250 \mathrm{~kW}$ and a refrigerant charge of only $85 \mathrm{~kg}$. The usual amount of R717 is often in the range of 300-1,100 kg. In 2012, it was installed on the ship MS Slettenberg (earlier MS Senjaland) and it has been working as expected since that time. The system is called SX cooler (see Figure 34 , left) and it is very effective, both when it comes to space requirement and energy consumption. Since 2013,25 systems have been delivered for 20 fishing vessels and 13 more are already in order to be delivered in 2016 and 2017. These systems have been delivered to countries like Ecuador, Ireland and Iceland (Widell, Eikevik, 2016). 
Figure 34: Left: MMC SX RSW unit, photo by Havyard. Right: RSW unit with spray chiller, from Teknotherm

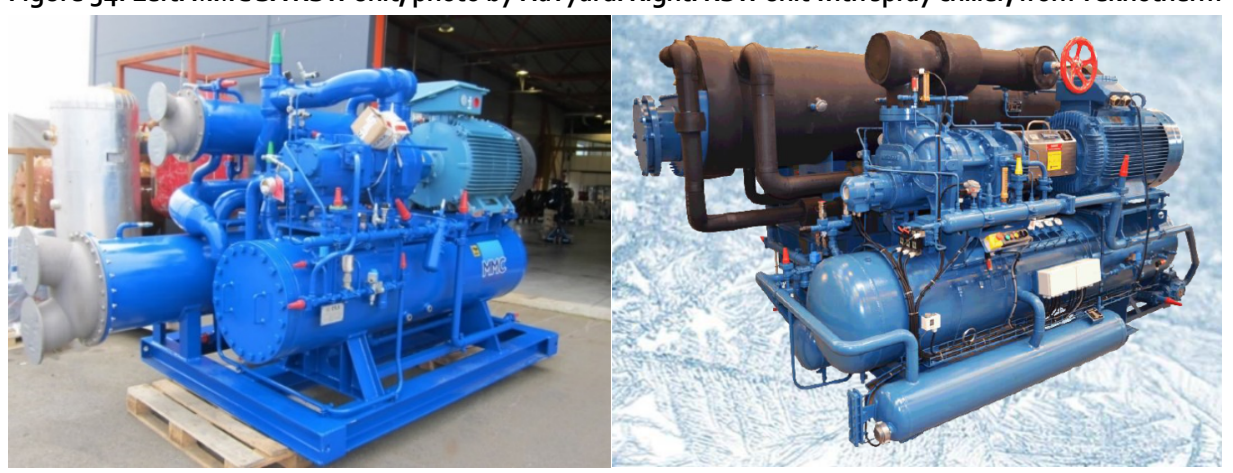

Another well-functioning R717 system was delivered to a Scottish trawler by the Norwegian company Teknotherm in 2015. It is shown in Figure 34, right. The ship has two systems where each has a cooling capacity of $1,000 \mathrm{~kW}\left(-5 / 30^{\circ} \mathrm{C}\right)$. The refrigeration systems were assembled in the factory and put into the ship as units. This is common practice and it reduces installation time on board. The evaporators are shell and tube type, where the water is inside the tubes and the refrigerant is sprayed on the outside. The spray type needs less filling of refrigerant than required for units with flooded evaporators (Widell, Eikevik, 2016).

\section{R744 systems}

R744 in RSW-systems was until some years ago not common on board of fishing vessels in Norway, nor in the rest of the world. Historically, there was an issue with high pressure, but the equipment nowadays tolerates this and components of different sizes exist or are being developed. Research activity at SINTEF and NTNU has contributed to the development of efficient and safe R744-systems. The main goal has been to develop environmentally friendly alternatives to synthetic refrigerant systems, but in some applications, it can also be an alternative to $\mathrm{NH}_{3}$. $\mathrm{NH}_{3}$ has strict regulations because of strong odor, toxicity and flammability. R744 systems are also more compact, which is especially important on ships, where space is limited. The refrigerant cost is low and will probably still be moderate in the future, compared with HFCs, which will have increasing tax regulations and availability issues in the years to come. The investment costs of R744 systems are higher than for example HFC systems, however, the total costs of ownership, i.e. including charge, taxes, operation and servicing makes only marginal differences.

The first RSW R744 system was built on MS Viking Midøy (earlier MS Båragutt) and it was launched early in 2012. The system has four Dorin transcritical compressors (one with variable speed), a flooded evaporator and a shell and tube condenser with R744 on the tube side. Titan was used in the heat exchangers. The capacity is $250 \mathrm{~kW}$ for cooling seawater to between $0^{\circ} \mathrm{C}$ and $1^{\circ} \mathrm{C}$, with an evaporator temperature of $-5^{\circ} \mathrm{C}$. The ship has six RSW tanks and the R744 system was supposed to cool three of these tanks, the other should be cooled with an old R22 system. It turned out that the R744 system had enough capacity to cool down all of the tanks, but the other system was still used for 
increasing the capacity during pull down cooling of the catch. (Ladam, 2012), (Widell, Ladam, 2013b). The system has worked as expected, also with varying ambient temperature and under harsh weather conditions (Ladam \& Rekstad, 2012).

Trønderhav (earlier Ambassador) is the second fishing vessel with a R744 RSW system in Norway. The system design and construction was made by CADIO AS, in cooperation with NTNU and SINTEF, and it was launched in 2014. The system consists of two separate systems each with a cooling capacity of $150 \mathrm{~kW}$, seen in Figure 35 . It is reported that the system works more stable than the previous system (a R22 system), with a RSW temperature of $-1.3^{\circ} \mathrm{C}$. The compressors are frequency controlled and can operate between 40 and $100 \%$ of the capacity, with good energy efficiency. A new plate heat exchanger of a so called "dimple type design", were developed both for the evaporator and the condenser. The new evaporator design was developed to simplify the opening and cleaning process. These evaporators are more compact than tube evaporators, which is especially important on a fishing vessel. After a short commissioning period, the system has worked well and without problems. The RSW system is operated from the bridge, which reduces the number of visits to the engine room. There is less noise and vibration from this system, because the compressors are smaller than in previous systems (Rekstad, Eikevik, Jensen, 2015), (Matre, 2015).

Figure 35: R744 RSW system from CADIO
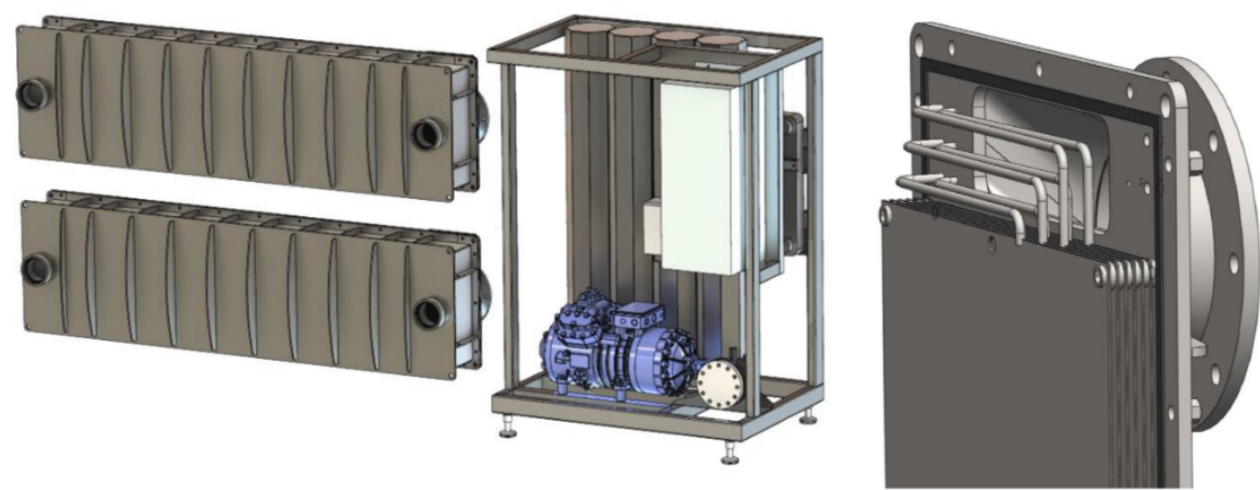

Source: Cadio, 2016.

\section{Combined RSW and freezing systems}

The R717 system in the fishing vessel Fugløyhav was described by (Widell, Ladam, 2013). This system can work either as a freezing system or as an RSW system. This gives the ship more flexibility to do fishing of additional types of fish, not only pelagic fish, but for example cod and saithe. These are filleted and frozen on board in plate freezers. This flexibility is especially important today and several ships have this kind of system. A disadvantage can be lower COP and challenges with refrigerant distribution.

R717 evaporation temperatures are seldom lower than $-40^{\circ} \mathrm{C}$. R744, on the other hand, has good properties at low temperatures and can operate below $-50^{\circ} \mathrm{C}$ (triple point, i.e. the operation limit is $-55^{\circ} \mathrm{C}$ ). When both cooling and freezing is required on a ship, a cascade system with $\mathrm{R} 744$ and $\mathrm{NH}_{3}$ is a better solution. 


\subsubsection{Passenger ships and cargo vessels}

Within the scope of this survey no installations with low-GWP refrigerants (HFCs and $\mathrm{HFC}$ blends or natural refrigerants) on passenger ships or cargo vessels are found. There are however systems available/under design phase, which will be presented below. Furthermore, solutions for increasing the energy efficiency and/or reducing refrigerant leakage rate are also represented.

According to correspondence with refrigeration companies, price is the deciding factor in which refrigerant is used. The fast-increasing prices of high-GWP refrigerants might be an opening to new systems and new refrigerants. For example, a Nordic shipowner is considering changing the direct AC plants on their cargo vessels to indirect ACplants, in order to decrease the amount of refrigerant leakage rate since the expenses for refilling with $\mathrm{R}_{4} \mathrm{O} 4 \mathrm{~A}$ has become very high.

Larminat (2017) states that marine refrigeration plants require special design, classification and approvals, but no radical technology change from land-based applications. Marine chillers are generally derived from standard off-the shelf products, which are "marinised" to accommodate the additional operating constraints, such as extra reliability, pitch and roll conditions, safety and corrosion.

\section{Indirect provision refrigeration systems}

According to Johnson Control the indirect systems are becoming more and more common for both provisions cooling and freezing on board cruise ships. $\mathrm{R}_{407} \mathrm{C}$ is often used in both cooling and freezing, since the pressure will be below atmospheric pressure if using R134a.

According to Pigani et al. (2016), one of the currently used systems for provision refrigeration on large cruise ships is a system composed of an indirect system for the provision cooling and a direct system for the freezing system (see Figure 36). Both systems use $\mathrm{R} 407 \mathrm{~F}$ as refrigerant and has a single stage screw compressor with an economizer. The chilling plant operates at an evaporation temp of $-14.5^{\circ} \mathrm{C}$ and the freezing plant at $-34^{\circ} \mathrm{C}$. 
Figure 36: Example of indirect provision refrigeration system on board cruise/passenger ship

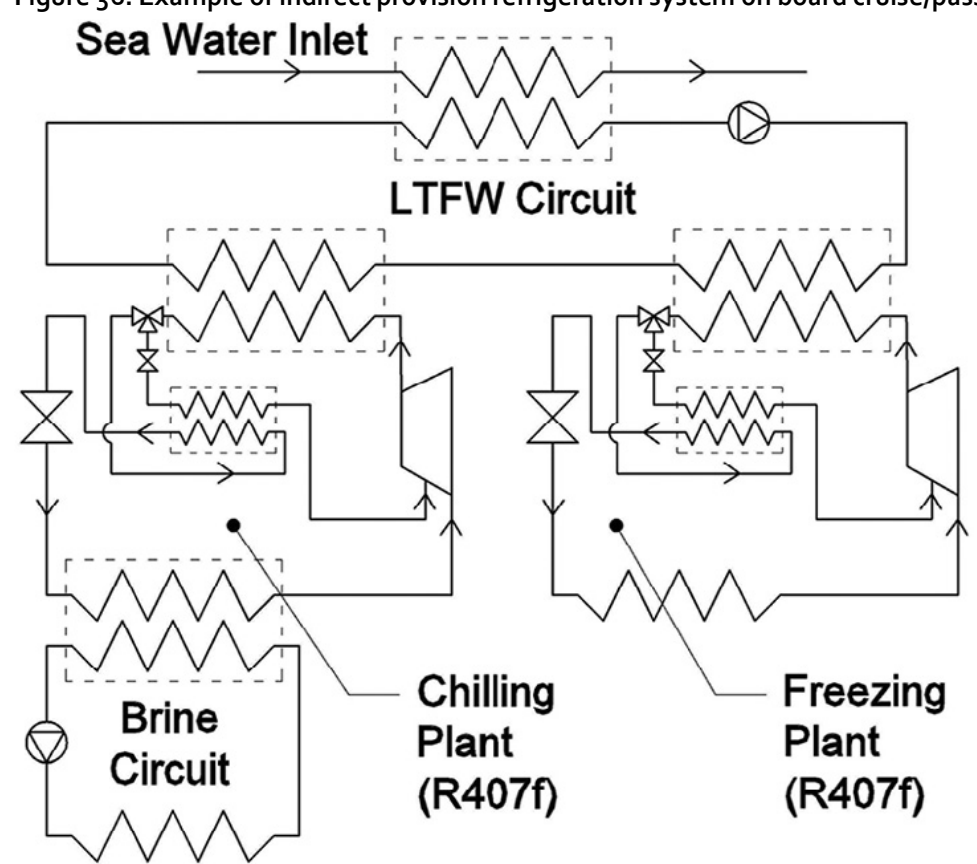

Source: Pigani et al. 2016.

\section{LNG cold recovery}

The number of ships using LNG as fuel is steadily increasing (DNV-GL, 2017b). In addition to reducing the emissions of $\mathrm{SO}_{x}, \mathrm{NO}_{x}$ and $\mathrm{CO}_{2}$ the use of LNG enables a reduction in the energy demand for the $A C$ compressors, since the cold LNG can be used for cooling in the AC system (Levander, 2010). This concept is used on the Finnish cruise ferry Viking Grace, with an LNG fuel system from Wärtsilä (see Figure 37). The LNG is stored at around $-135^{\circ} \mathrm{C}$ and is evaporated and heated to around $25^{\circ} \mathrm{C}$ before it is supplied to the engine. This heating is provided by the HVAC water loop and the lowtemperature engine cooling water loop (LT-water) (Zoglia, 2013). 


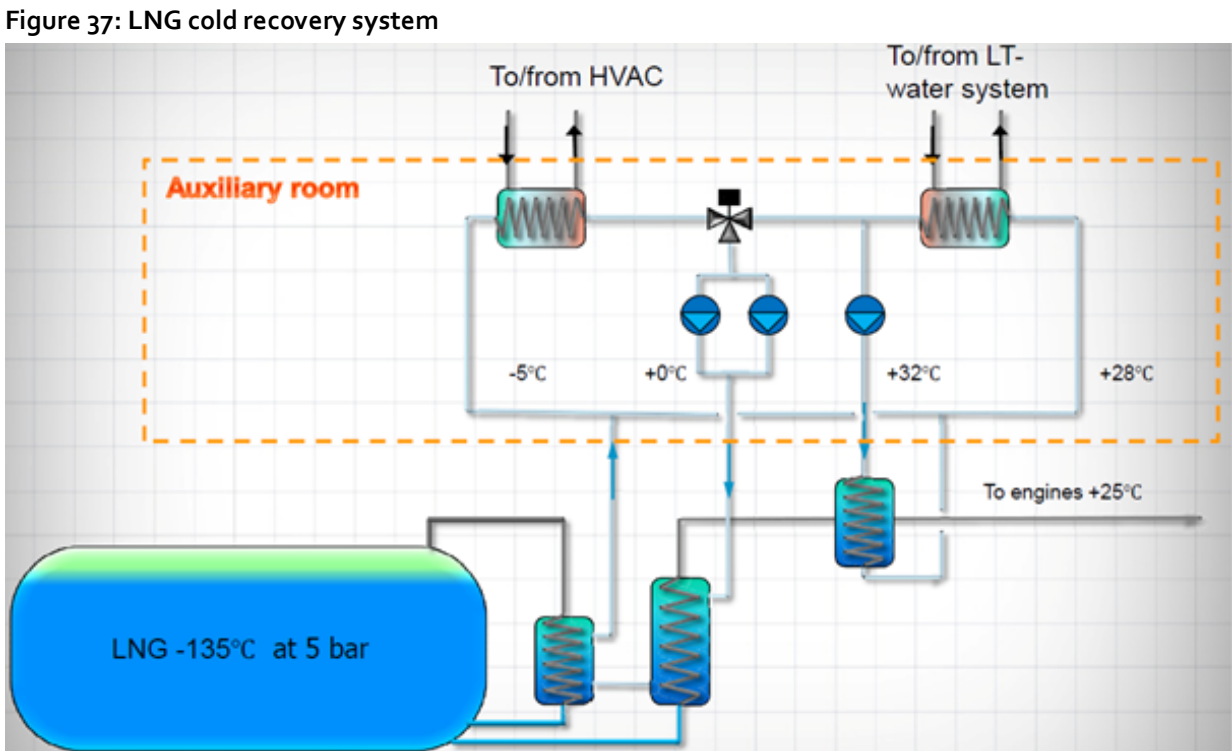

Source: Zoglia, 2013.

\section{Absorption chiller for the AC system}

Absorption cooling is a technique that has been used for many years in land-based installations. The absorption chillers use heat to drive the refrigeration cycle, producing chilled water to the HVAC system. The electricity consumption is very low, and when waste heat is used as heat source the energy efficiency becomes very high.

On board a marine vessel there are waste heat sources available that can be used to drive an absorption chiller; steam/hot water produced by the main engine exhaust gases (EHG), or "hot" cooling water from the main engine. The main advantages compared to a compressor-driven refrigeration system is the reduction in the ships fuel consumption and the use of an environmentally friendly (zero-GWP), non-toxic and non-flammable refrigerants (e.g. LiBr-water-solution).

In 2012 an absorption chiller was installed on the cruise ship AIDAmar. The heat source is waste heat from the diesel engine's cooling water (around $80-90^{\circ} \mathrm{C}$ ), and the cooling capacity is $1,200 \mathrm{~kW}$. The absorption chiller is also connected to the desalination unit for production of drinking water (FisheRgroup, 2012).

The current use of absorption cooling on board ships is however rare, mainly due to the following challenges:

- the ship movements have possible negative impact on the functioning of the absorption cooler, such as refrigerant overflow and mixing;

- the higher investment costs and larger space requirements compared to a compressor-driven chiller;

- the need for a back-up system when there is no waste heat available (when the main engines are not running). 
There are a today some companies, e.g. Johnson Controls Hitachi (see Figure 38), Teknotherm (2017b), Heinen \& Hopman (2017) and Gadcooler (2016) offering absorption chillers customized for marine vessel conditions with anti-rolling and pitching constructions, approved by classification societies. The systems produce chilled water of around $6-10^{\circ} \mathrm{C}$ and have a cooling capacity of $150-2,500 \mathrm{~kW}$. The COP value is around $0.7-0.8$ but since the driving heat source is waste heat (hot water at 75$90^{\circ} \mathrm{C}$ or steam at $1-3 \mathrm{barg}$ ) it is an energy efficient solution. In Figure 38 and Table 5 below the technical data is presented for a marine chiller absorption unit from Hitachi and Johnson Controls.

Figure 38: Marine absorption chiller. Technical data in Table 5.

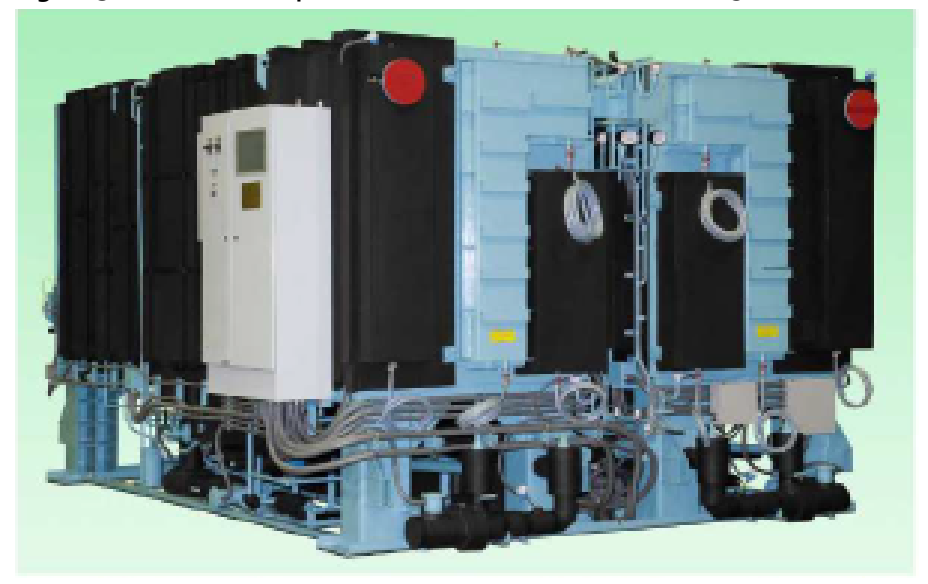

Note: Model HAU-CL6ooEXE2TM 2unit (2013).

Source: Nautic Expo, 2017.

Table 5: Data for the marine absorption chiller pictured in Figure 38.

\begin{tabular}{ll} 
Technical data & \\
\hline Cooling capacity & $2000-2500 \mathrm{~kW}$ \\
Chilled water temp & $12 / 6^{\circ} \mathrm{C}$ \\
Chilled water flow & $270 \mathrm{~m} / \mathrm{h}$ \\
Cooling water temp & $32->28 / 33.5^{\circ} \mathrm{C}$ \\
Cooling water flow & $880 \mathrm{~m}^{3} / \mathrm{h}$ \\
Driving heat source temp & $90 / 82.8^{\circ} \mathrm{C}$ \\
Driving heat source flow & $449 \mathrm{~m}^{3} / \mathrm{h}$ \\
\hline
\end{tabular}

Source: Nautic Expo, 2017.

The need for a back-up system (when the main engines are not running) can be solved by either having an electric chiller as back-up or a hybrid system that could be direct fired with a gas or oil fuel burner. Other possible solutions could be to produce the hot water/steam by solar panels, or use storage of the waste heat. Another possible future solution would be to use heat recovery from a R744 refrigeration plant as heat source to the absorption chiller. 
Systems with HFC blends and unsaturated HFCs

Air Conditioning: According to Kylkontroll Göteborg $A B$, they have recently received an order from a shipping company to change their direct $A C$ system with $\mathrm{R}_{40} \mathrm{~A} A$ to an indirect system using R1234ze.

Johnson Controls has tested their centrifugal AC chiller (see Figure 39), normally using R134a, with the HFC mixture R513A, giving the same cooling capacity and a reduction of $2 \%$ in performance. $R_{513} A$, with a GWP of 613 , is a mixture of R $1234 y z$ and $\mathrm{R} 134 \mathrm{a}$, in order to reduce the flammability compared to pure R1234yz. The flammability of $R_{513} A$ is just below the limit for an additional fire classification of the machinery space. Johnson Control believes that the price of $\mathrm{R}_{513} \mathrm{~A}$ will be lower than pure $\mathrm{R}_{134 \mathrm{a}}$ in 2018, which will probably increase the use of this refrigerant.

Figure 39: Centrifugal chiller that can use R513A instead of R134a

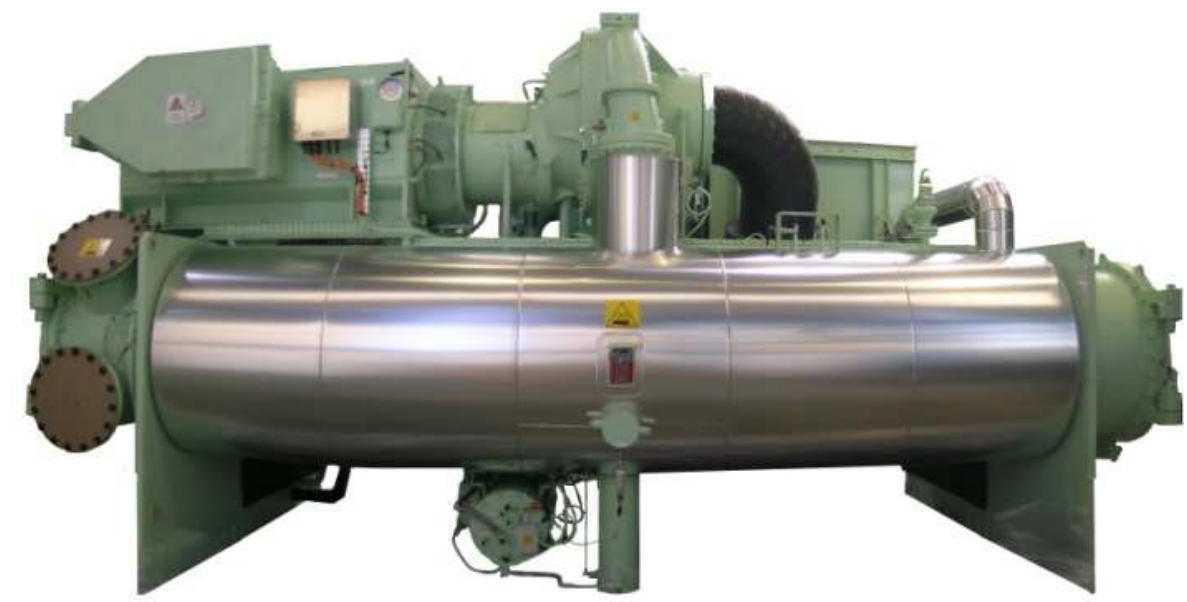

Source: Johnson Controls.

According to Larminat (2017) possible future alternative refrigerants for AC systems on large cruise ships are:

- the very low GWP synthetic fluids R1234ze and R1234yf, but ship-owners are reluctant to use even mildly flammable fluids (See also chapter 3.2);

- the near drop-in replacement R513A which is non-flammable and technically viable but today more costly;

- the low-pressure fluid R1233zd, but low pressure means larger suction volume, i.e. much larger plants.

Provision refrigeration: In Figure 40 and Table 6 Johnson Control and York present their "chill and freeze for the future", which enables the use of R407F but also the HFC blends including HFOs like R442A and R449A as well as systems containing only flammable R1234yf. 


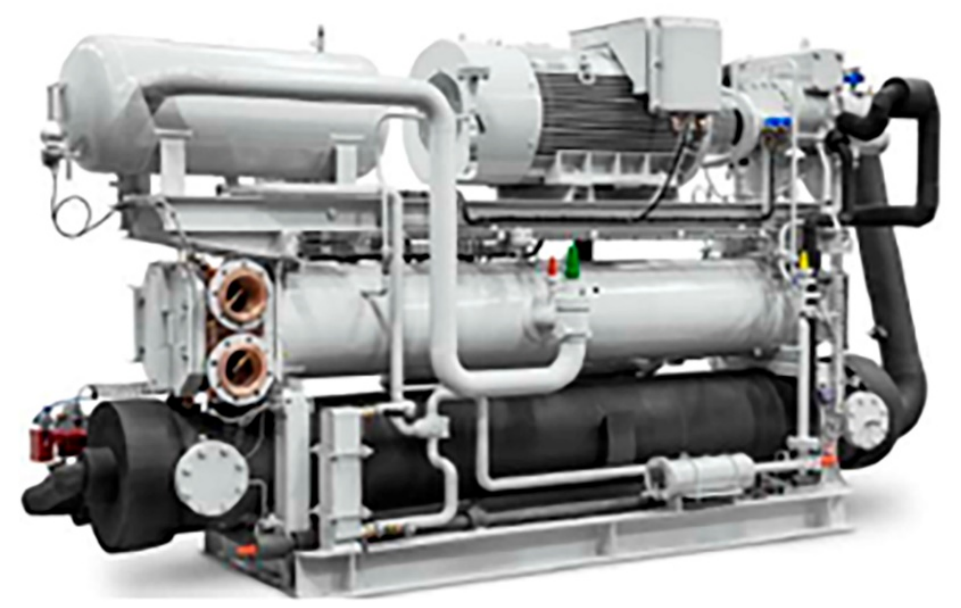

Source: Johnson Controls.

Table 6: Technical data for chiller/freezer pictured in Figure 40 when using different refrigerants. Chill XJF120S

\begin{tabular}{|c|c|c|c|c|c|}
\hline & $\mathrm{R}_{4} \mathrm{O}_{4} \mathrm{~A}$ & $\mathrm{R}_{407} \mathrm{~F}$ & R449A & $\mathrm{R} 442 \mathrm{~A}$ & R1234yf \\
\hline Cooling capacity & $100 \%$ & $103 \%$ & $92 \%$ & $99.5 \%$ & $97 \%$ \\
\hline Shaft power & $100 \%$ & $100 \%$ & $89 \%$ & $100 \%$ & $90 \%$ \\
\hline GWP & 3922 & 1824 & 1397 & 1888 & 4 \\
\hline Design pressure & 25 bar & 27.6 bar & 25 bar & 27.6 bar & 14 bar \\
\hline \multicolumn{6}{|l|}{ Freeze XJF120S } \\
\hline & $\mathrm{R}_{4} \mathrm{O}_{4} \mathrm{~A}$ & $\mathrm{R}_{407} \mathrm{~F}$ & R449A & $\mathrm{R}_{442 \mathrm{~A}}$ & R1234yf \\
\hline Cooling capacity & $100 \%$ & $94 \%$ & $86 \%$ & $94 \%$ & $93 \%$ \\
\hline Shaft power & $100 \%$ & $98 \%$ & $93 \%$ & $104.7 \%$ & $86 \%$ \\
\hline GWP & 3922 & 1824 & 1397 & 1888 & 4 \\
\hline Design pressure & 25 bar & 27.6 bar & 25 bar & 27.6 bar & 14 bar \\
\hline
\end{tabular}

Source: Johnson Controls.

In the different systems investigated by Pigani et al. (2016) and described below, some of the working fluids investigated to replace $\mathrm{R}_{407} \mathrm{~F}$ for provision refrigeration on a cruise ship are also HFOs like R1234yf and R1234ze, with a GWP of 4 and 6 respectively, see Chapter 3.2 describing their environmental impact and safety issues.

\section{R744 systems}

Provision refrigeration: Johnson Controls foresees that, within five years, a large part of new installations of cooling/freezing plants on board cruise ships will be indirect R744plants, with glycol as secondary fluid for cooling plants and Hycool/Pekasol (formiat) as secondary fluid for freeze plants.

Johnson controls has promoted R744 for a while and puts large efforts on developing these plants. A system that can manage pressures up to go bar (stand still 
pressure) will be needed so the charge will remain inside the system when the unit is switched off for service at high ambient temperature conditions. Johnson Control manufactures also R744 compressors, however only for low temperature applications with 30 bar design pressure, which are used in land-based plants. In these plants the system "empties itself" during standstill and new R744 is charged at start-up. This release of $\mathrm{R} 744$ is not an option on passenger ships, thus the design (stand still) pressure must be go bar. Such compressors are today manufactured by other companies, see also further work in Chapter 6.

According to Wilhelmsen Ships Service R744 could, for example, be used in indirect systems equipped with a number of compact R744 units, supplying several freezer storage rooms on passenger/cruise ships.

Teknotherm's product catalogue from 2012 includes an R744 - HFC cascade system for provision room refrigeration (see Figure 41 and Table 7). According to correspondence with Teknotherm this system did not sell, and is therefore not offered today. Instead Teknotherm are heading at developing systems using only R744. It is however pointed out that for large provision refrigeration systems the cascade system could still be a viable solution. To reduce the HFC (R134a) charge the chilling plant could be an indirect system using R134a. However, Teknotherm believes that it is more reasonable to use direct expansion systems for both chilling and freezing plants.

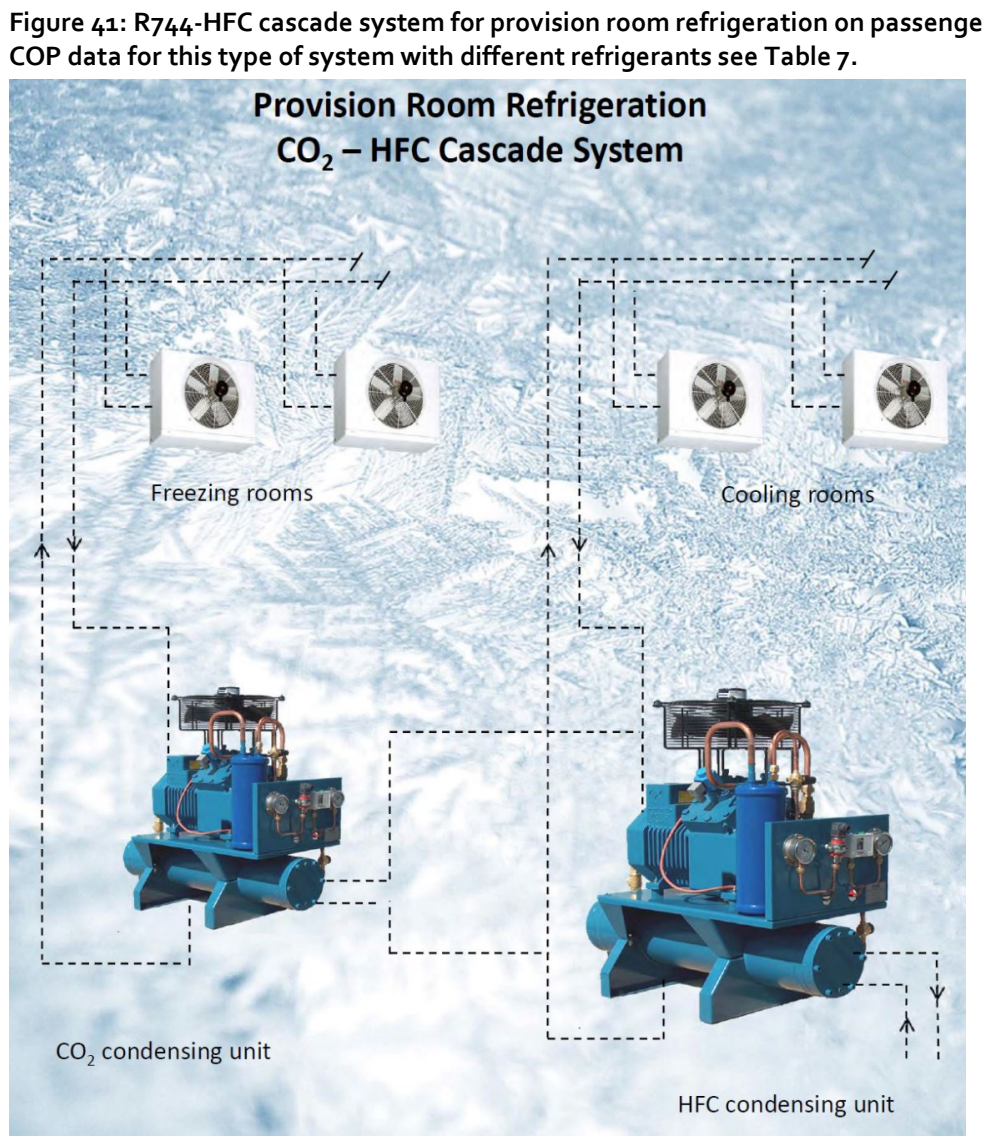

Source: Teknotherm, 2012. 
Table 7: Coefficient of Performance (COP) comparison with some typical refrigerants for the system pictured in Figure 41.

\begin{tabular}{llll} 
Refrigerant & System temperatures & Compressor & COP \\
\hline $\mathrm{CO}_{2} / \mathrm{R}-134 \mathrm{a}$, cascade & $\mathrm{T}_{E} / \mathrm{T}_{\mathrm{M}} / \mathrm{T}_{\mathrm{C}}:-35 /-8 / 45^{\circ} \mathrm{C}$ & semi. recip. compressor & 1.5 \\
R-134a, single stage & $\mathrm{T}_{E} / \mathrm{T}_{\mathrm{C}}:-35 / 45^{\circ} \mathrm{C}$ & semi. recip. compressor & 0.8 \\
R-134a, single stage & $\mathrm{T}_{E} / \mathrm{T}_{\mathrm{C}}:-35 / 45^{\circ} \mathrm{C}$ & open screw compressor, eco & 1.25 \\
R-404A, single stage & $\mathrm{T}_{E} / \mathrm{T}_{\mathrm{C}}:-35 / 45^{\circ} \mathrm{C}$ & semi. recip. compressor & 1.0 \\
R-404A, single stage & $\mathrm{T}_{E} / \mathrm{T}_{\mathrm{C}}:-35 / 45^{\circ} \mathrm{C}$ & open screw compressor, eco & 1.2
\end{tabular}

Source: Johnson Controls.

According to Kylkontroll Götbeorg AB, the use of $\mathrm{R} 744$ as refrigerant is much discussed for land-based plants, but not yet for marine installations, which is probably due to the rigorous safety regulations that exists today regarding $\mathrm{CO}_{2}$ used in firefighting systems on board merchant ships.

In the systems layouts studied by Pigani et al. (2016), and described below, R744 is investigated as refrigerant in the freezing part for all system layouts, and in the cooling plant for some of the system layouts. However, the system using R744 as the single working fluid has to be adapted to what is state of the art in commercial refrigeration systems, enabling a more energy efficient use of R744 systems compared to HFC units, independent on global climate conditions.

\section{Systems with R744 and HFCs}

Pigani et al. (2016), in co-operation with the Fincantieri Shipyard, studied theoretically the use of low-GWP refrigerants for provision refrigeration plants on cruise ships. The refrigerants included in the study are $\mathrm{R}_{1234 \mathrm{yf}}$ and $\mathrm{R} 1234 \mathrm{ze}$ as well as the natural refrigerants $\mathrm{R}_{717}$ (ammonia) and $\mathrm{R} 744\left(\mathrm{CO}_{2}\right)$. The performance when using these refrigerants for a number of different system layouts was compared with the current systems using R407F.

For the systems investigated consisting of separate cycles for chilling and freezing plants, the refrigerant in the chilling plant was either one of the four fluids, while for the freezing plant R744 is proposed. The chilling system can be equipped with either an internal heat exchanger (except for R717, which would result in too high discharge temperature) or an economizer (except for R744, since this system uses reciprocating compressors, for which the technology with an economizer port does not exist today). However, this economizer technology is state of the art in commercial refrigeration, called parallel compression.

Two different types of cascade systems were suggested:

- A chilling plant, using R1234yf, R1234ze or R717, equipped with an economizer and works in cascade with the freezing plant using R744. This configuration enables a subcritical R744 plant;

- A two-stage system with flash tank using R744 as the only refrigerant. 


\section{R717 systems}

Johnson Controls is also investigating R717 as an alternative to provision cooling on cruise ships, but does not really believe that $\mathrm{R} 717$ is an option on passenger ships. As mentioned above, Pigani et al. (2016) also investigates R717 as a possible refrigerant, for example in a cascade system with R744. However, it is pointed out that even if leakages of R717 are easily identifiable by its distinct odour it constitutes an additional risk since the strong odour may cause panic among passengers.

Integration of provision refrigeration and HVAC

As stated by Pigani et al. (2016) the HVAC systems on passenger ships, producing chilled water at a temperature of around $7^{\circ} \mathrm{C}$ to be used as secondary fluid in the air handling unit, are usually separated from the provision refrigeration plants. However, instead of using sea water or fresh water from the main engine cooling water to reject heat from the condenser, the chilled water in the HVAC system could be used. In case of using R744 as refrigerant, this would enable both the chilling and freezing plant to work at subcritical conditions.

Figure 42 shows one of the systems suggested by Pigani et al. (2016). The chilled water from the HVAC chiller is applied as the secondary cooling fluid receiving the condenser heat, instead of cooling water from the engine, for the separate provision chilling and freezing plants. The chiller plant could apply R1234yf, R1234ez, R717, hydrocarbons or R744, and the freezing plant is using R744. 


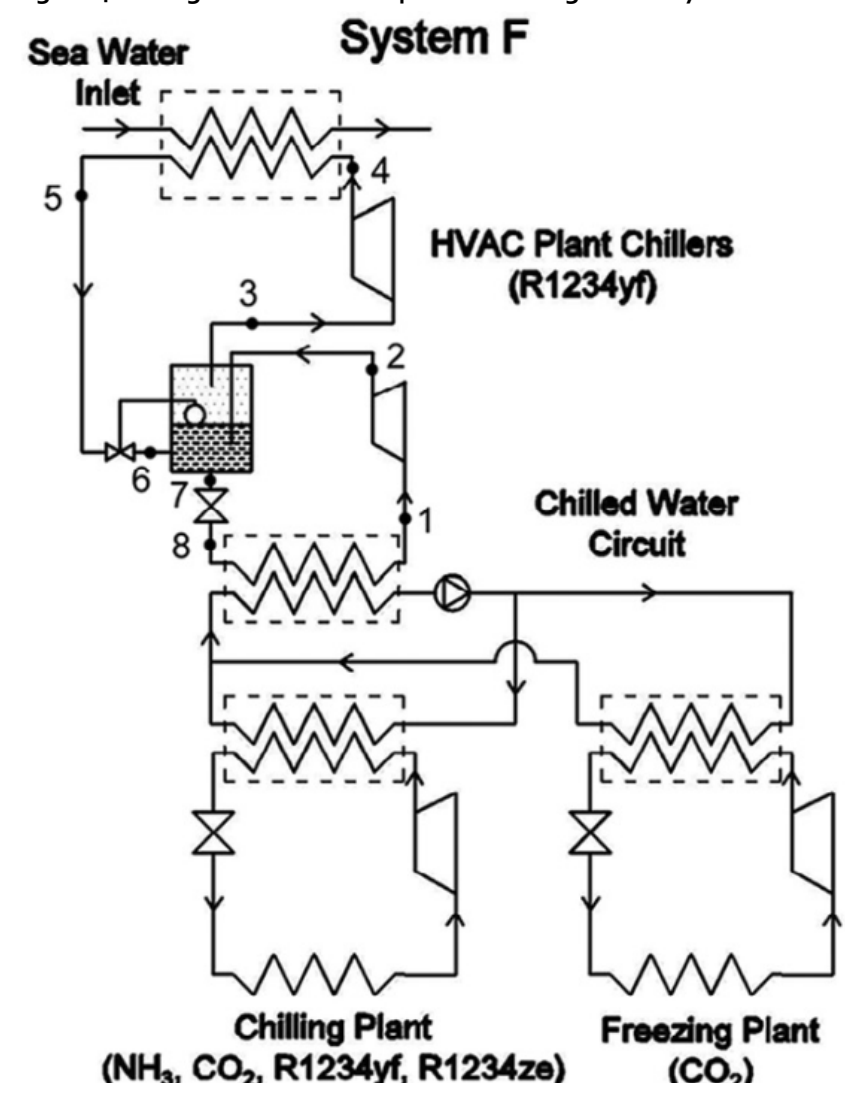

Source: Pigani et al., 2016.

This concept is also proposed by Johnson Controls in their development of future R744plants, in order to enable simple R744 refrigeration units, which do have a high energy efficiency when the HVAC return chilled water $\left(12^{\circ} \mathrm{C}\right)$ is used as cooling media for the condenser. The load on the HVAC chiller will be higher; however, the system complexity is low. As seen in Figure 43 (column " $\mathrm{CO}_{2}$ std"), the yearly energy consumption for the provision plant can be decreased by $18 \%$, compared to using a system with $\mathrm{R}_{407} \mathrm{C}$ and no integration with the HVAC system. 
Table 8: Comparison of the power and energy consumption of the systems pictured in Figure 43, with different refrigerants and options.

\begin{tabular}{|c|c|c|c|c|c|c|}
\hline & \multicolumn{3}{|l|}{$100 \%$} & \multicolumn{3}{|l|}{$70 \%$} \\
\hline & Std HFC R407C & $\mathrm{CO}_{2}$ std & $\begin{array}{l}\mathrm{CO}_{2} \text { heat } \\
\text { recovery }\end{array}$ & $\begin{array}{l}\text { Std HFC } \\
\mathrm{R}_{407 \mathrm{C}}\end{array}$ & $\mathrm{CO}_{2}$ std & $\begin{array}{l}\mathrm{CO}_{2} \text { heat } \\
\text { recovery }\end{array}$ \\
\hline Heat Power [kW] & & 55 & 177 & & 39 & 124 \\
\hline Chill Cooling Cap 100\% [kW] & 168 & 168 & 168 & 102 & 102 & 102 \\
\hline Chill el Power [kW] & 85 & 55.9 & 89.5 & 52 & 34.6 & 53.7 \\
\hline Chill Power from HVAC [kW] & o & 33 & 17 & 0 & 20 & 10 \\
\hline COPHVAC & & 6.5 & 7.5 & & 6.5 & 6.5 \\
\hline Freeze Cooling cap 70\% [kW] & 36.9 & 36.9 & 36.9 & 24.5 & 24.5 & 24.5 \\
\hline Freeze El Power [kW] & 34 & 9.3 & 9.3 & 23 & 6.2 & 6.2 \\
\hline Total load [kW] & 120 & 98 & 116 & 76 & 61 & 69 \\
\hline Total 36od [MWh] & 1047 & 862 & 1014 & 664 & 531 & 609 \\
\hline
\end{tabular}

Source: Johnson Controls.

Figure 43: Integrated HVAC and provision refrigeration system using R744 with and without heat recovery. Technical data in table 8.
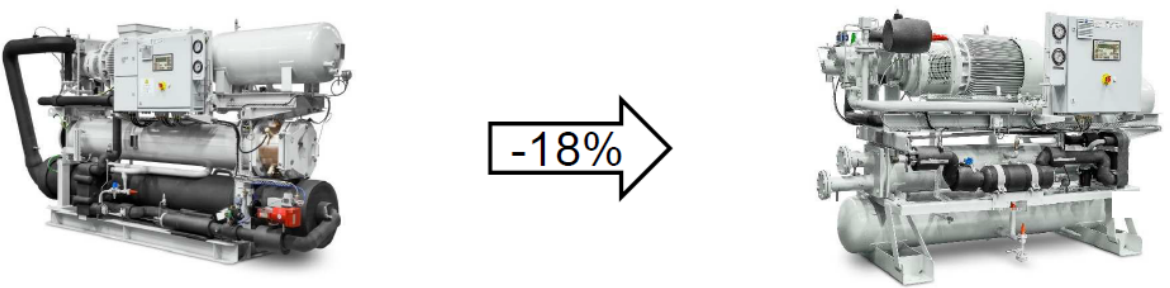

Source: Johnson Controls.

Integration of provision refrigeration and HVAC - heat recovery or absorption cooling

As suggested by Johnson Controls it would also be possible to produce hot water from the R744 plant, which could, on cruise ships, be used for covering parts of the heat demands on board (especially when connected to el-power in a harbour) or as heat source to an absorption cooling aggregate. The performance of this concept is also seen Figure 43 (column " $\mathrm{CO}_{2}$ heat recovery").

\section{Variable condenser temperature}

As stated by Pigani et al. (2017) most of the systems using the engines' low temperature cooling water for cooling the condenser are designed to maintain the cooling water at constant temperature (around $36-38^{\circ} \mathrm{C}$ ). However, allowing the cooling water temperature to vary would increase the energy efficiency at low seawater temperatures. Also, if using seawater as cooling water for the condenser, an electronic device would enable the plant to work more efficiently at low sea water temperatures, especially $\mathrm{R} 744$ systems can achieve very low temperature approaches 
in the gascooler (difference between seawater inlet- and R744 outlet temperature), i.e. a superior energy efficiency can be achieved at low sea water temperatures with standard control devices.

Traditionally, according to the classification societies' general rules for ships the AC and refrigeration equipment have to be able to operate at a sea water temperature up to $32^{\circ} \mathrm{C}$. For example, according to DNV GL (2013):

\footnotetext{
"all machinery, components and systems covered by the rules are to be designed to operate under the following environmental conditions if not otherwise specified in the detailed requirements for the machinery, component or system: - ambient air temperature in the machinery space between $0^{\circ} \mathrm{C}$ and $55^{\circ} \mathrm{C}$, - relative humidity of air in the machinery space up to $96 \%$, - sea water temperature up to $32^{\circ} \mathrm{C}$.
}

However according to newer rules from DNV-GL (2015) it is stated that "The Society may approve other temperatures in the case of ships not intended for unrestricted service". This enables an improved control of the condensing temperature and thereby a lower power consumption.

\subsubsection{Alternative fluids for other applications on board}

$O R C$ : In a demonstration plant on a container vessel the refrigerant R245ae with a GWP of 1030 was used (Haglind et al., 2017). There are also a number of theoretical investigations regarding suitable working fluids for marine ORC plants. However, as for alternative refrigerants to be used in refrigeration plants there is a trade-off between energy efficiency, GWP and flammability (Larsen et al. 2013, Ahlgren et al., 2016).

Fixed firefighting systems: Alternatives to HFC gases are gas extinguishing systems using natural substances like argon, nitrogen or $\mathrm{CO}_{2}$ (DNV-GL, 2017a). 


\section{Conclusions}

This report has described several different aspects of refrigeration on board marine vessels, mainly in the Nordic countries. In fishing vessels, there are mainly refrigeration units for cooling or freezing of the catch. Passenger ships and cargo vessels have plants with a wide range of cooling capacities, to provide passengers and crew with air conditioning and preserve refrigerated food.

Refrigerants that are available today are divided into three groups; saturated hydrofluorocarbons, unsaturated hydrofluorocarbons and natural working fluids. The refrigerants from the first two groups all affect the climate and/or the environment and they are therefore part of phase-out programs. There are less harmful hydrofluorocarbons, but it is still recommended that this industry convert most of the refrigerants to natural working fluids. It has repeatedly been shown that fluids that seemed to have good properties, later has shown some unknown negative effects for the environment. There are also safety issues with natural working fluids, but these can be solved with proper technical safety strategies and available technology. Ammonia is toxic, but has been successfully applied in refrigeration systems since 150 years. Carbon Dioxide is the only ASHRAE classified non-flammable A1 fluid. It has high working pressure which is not a technical issue, but the pipe and component sizes can be significantly reduced, which is especially important when space is limited. Another limitation with R744 is that today's compressors are not large enough and several parallel compressors are necessary for systems, which require megawatts of cooling capacity. This will be solved in the near future and it is also therefore necessary with focus on further development, as suggested in the following sections. Risk of flammability of natural working fluids can be prevented by reduced charge systems and well-trained operators.

The risks related to the use of the newly introduced HFOs when it comes to human health and safety are not fully understood. In the past, numerous cases are on record where new chemicals, believed to be a benefit to man, have turned out to be environmentally unacceptable, sometimes even in quite small quantities.

The recommendation is to continue and strengthen the good research and development of natural refrigerant systems for marine vessels. It will also be necessary to intensify the knowledge transfer and information distribution to all stakeholders in this sector. 


\section{Suggestions for further work}

The following proposed actions are a summary of the feedback to a survey describing actions that will support a faster phase in of alternative refrigeration solutions within the various maritime sectors.

\subsection{Communication and information exchange with classification societies}

According to Johnson Control and others, the largest barrier for introducing R744 plants in the shipping market is that the classification societies has not yet finalized their regulations/rules for safety and operations. When these regulations/guidelines are clear for their customers (shipping yards and companies) it will be much easier and faster to adapt and implement e.g. R744 units into all kind of ships.

Johnson Controls believes that there will be more requirements for alarm installations when using $\mathrm{R} 744$ as refrigerant. The classification societies are currently investigating this. Today, refrigerant leakage detectors only have to be installed in the engine rooms, not in the cold storage rooms in case of direct expansion systems. Probably, when using R744, leakage detectors ${ }^{11}$ have to be installed also in the cold rooms.

Proposed actions:

- Arrange a workshop including DNV GL, Loyds etc. as well the major original equipment manufacturers (OEM) from the Nordic countries and authorities like DSB from Norway.

- Draft Agenda:

- Describe state of the art refrigeration systems;

- Establish understanding of integrated system design approach including the energy efficiency benefits and reduced space requirements (avoid pumped circuits) when applying R744 direct expansion evaporators and direct heating within the HVAC units;

- Safety concerns related to HFOs;

- OEM suggestions for specifications and safety measures.

${ }^{11}$ Standard in commercial refrigeration plants and pubs, i.e. many global equipment suppliers. 


\subsection{Support for dissemination of measurement results from pilot/demonstration plants on board various kind of ships}

Implementation of novel pilot systems has certain risks (financial and technical) both for the supplier of the unit and the end-user. By providing public funding, which can support a close cooperation between industry and academia; it is possible to minimize technology risks. Universities and research institutes can help to evaluate design options based on theoretical investigations and/or laboratory validation. Widespread exploitation of results is normally not in the interest of vendors supplying new units, however, when research institutes/universities are part of the development team, global knowledge transfer is possible via scientific publications and popular science articles.

Proposed actions:

- Implement national/Nordic demonstration project with potential for global exploitation for the next generation of:

- Compact refrigeration units for small fishing vessels;

- Integrated refrigeration \& heat pump units for factory ships (processing catch on board) -> providing: steam, pressurised hot water, AC, chilling and freezing;

- Integrated refrigeration \& heat pump units with direct expansion heat exchangers for passenger ships (high energy performance units, including AC, hot water production, chilling, and freezing).

\subsection{Establish a Nordic Technology Hub for global marine refrigeration research and development (R\&D)}

The initial task of the R\&D Hub should be the development of design guidelines for marine refrigeration systems with no environmental impact. Nordic funding should be provided which enables a core team to engage global experts from academia and industry to collect and document know-how related sustainable design options for various refrigeration systems in the maritime sector. Another task will be to organize annual workshops as part of global venues in this sector.

Proposed actions:

- Establish a Nordic Technology Hub for HVAC\&R ${ }^{12} R \& D$ with participants form all funding countries:

- Participants: Research Institutions and universities;

- Board: Representatives for main end-user and manufacturing organisations, classification societies, governmental representatives and NGOs.

${ }^{12}$ HVAC\&R Heating Ventilation Air Conditioning \& Refrigeration. 
- Development of design guidelines and a data base for maritime HVAC\&R equipment;

- Develop the life cycle climate performance (LCCP) approach for maritime applications;

- Engage professional website providers and establish an online knowledge hub for maritime refrigeration technology, as for example:

- www.R744.com; www.ammonia21.com; www.hydrocarbons21.com

- Organise workshops at global maritime events to disseminate and exploitation the latest achievements within the sector and promote technology from Nordic companies.

\subsection{Development support for dedicated components}

Compressor development: Refrigeration systems for maritime applications require adapted compressors. Currently there are no large capacity compressors for R744 refrigeration units on the market, i.e. to implement integrated systems with several megawatt capacity is often not possible due to space requirements. This is the case both for the low temperature (freezing below $-50^{\circ} \mathrm{C}$ ) with screw compressors and for high-pressure compressors enabling to operate the system in a transcritical cycle.

Proposed actions:

- Support the development (national/Nordic funding) of maritime R744 compressors, enabling a fast phase in of high performance R744 refrigeration units in the different sectors.

Heat exchanger development: Seawater cooled heat exchangers are crucial components with respect to energy efficient systems. The temperature difference between the seawater and the refrigerant is directly related to the performance of the system. Novel designs are needed to reduce servicing and maintenance costs and down time. When high pressure heat exchangers are developed, transcritical R744 refrigeration units can be applied. Well-designed counter flow gascoolers can achieve a temperature difference of 1 Kelvin, due to heat rejection at gliding temperatures, compared to several Kelvins required when applying a fluid, which condenses inside the unit.

Proposed actions:

- Support the development of maritime R744 heat exchangers, enabling a fast phase in of high performance $\mathrm{R} 744$ refrigeration units in the different sectors. 


\section{References}

Ahlgren, F., Mondejar, M. E., Genrup, M., Thern, M. (2016). Waste Heat Recovery in a Cruise Vessel in the Baltic Sea by Using an Organic Rankine Cycle: A Case Study. J. Eng. Gas Turbines Power 138(1). https://doi.org/10.1115/1.4031145

Andréasson, J., Band, W. (2017). A comparative study of refrigerant leakage on board ships and land-based facilities. Bachelor thesis, Chalmers University of Technology, Sweden.

British Refrigeration Association Action Group (2018) http://www.feta.co.uk/uploaded_images/files/BRA/PURR\%202\%20Final\%20Draft\%20160118. pdf

Carrier Marine \& Offshore (2017). https://www.carrier.com/marine-offshore

Danish Shipowners' Association (2016). Danish Shipping Statistics May 2016.

DNV (2011). Regulations and alternative fire fighting systems. Paper series No. 2001-Poo2.

DNV (2013). Rules for Classifications of Ships, Part 4 Chapter 1. Newbuildings Machinery and Systems - Main Class, Machinery Systems, General, January 2013.

DNV (2015). Rules for Classification of Ships, Part 6 Chapter 12. Newbuildings Special Equipment And Systems - Additional Class, Environmental class, Edition July 2015.

DNV-GL (2017a). Rules for Classification Ships, Part 6, Additional class notations, Chapter 7. Environmental protection and pollution control. Edition January 2017.

DNV-GL (2017b). https://www.dnvgl.com/maritime/lng/ships.html

Equasis Statistics (2017). The world merchant fleet in 2017. Statistics from Equasis: http://www.emsa.europa.eu/publications/technical-reports-studies-and-plans/item/472annual-statistical-report-on-the-world-merchant-statistics-from-equasisics-fromequasis.html

European Commission (2006). Regulation (EC) No 842/2006 of the European Parliament and of the Council of 17 May 2006 on certain fluorinated greenhouse gases.

European Commission (2014). Regulation (EU) No 517/2014 of the European Parliament and of the Council of 16 April 2014 on fluorinated greenhouse gases and repealing Regulation (EC), No 842/2006.

FETA (2018). An introduction to A2L refrigerants and their use in Refrigeration, Air Conditioning and Heat Pump applications. http://www.refcom.org.uk/media/1202/an-introduction-to-a2lrefrigerants-final.pdf

FisheRgroup (2012):

http://www.fischeRgroup.com/en/fischer_news/news_de/2012_05_24_Absorptionskaeltemas chine_AIDA.php

Frejd, T., Himmelmannn, O. (2017). The energy efficiency of retrofitted refrigeration plants onbaord ships. Bachelor thesis, Chalmers University of Technology, Sweden.

Gadcooler (2016). http://www.gadlab.fi/wpcontent/uploads/2016/og/Gadcooler_BROCHURE_2016.pdf

Gielle Marine (2017). http://www.giellemarine.com/

Haglind, F., Montagud, M. E. M., Andreasen, J. G., Pierobon, L., Meroni, A. (2017). Organic Rankine cycle unit for waste heat recovery on ships (PilotORC). Technical University of Denmark (DTU).

Halotron (2017). www.halotron.com

Heinen \& Hopman (2017). https://heinenhopman.com/heinen-and-hopman/pdfsgecomprimeerd/hh-maritime-absorption-chiller.pdf 
Hognes, E. S., Jensen, J. I. (2017). Drivstofforbruk og klimaregnskap for den norske fiskeflåten. Utviklingen fra 2001 til 2015. Report Sintef Ocean. 14 March 2017.ISBN 978-82-7174-276-8.

Gluckmann Consulting (2016). EU F-gas Regulation Guidance Information Sheet 31: Marine Refrigeration and AiRConditioning. http://www.gluckmanconsulting.com/wpcontent/uploads/2014/12/IS-31-Marine-Applications.pdf

Göteborg Brandservice (2017). https://www.gbgbrandservice.se/produkter/slackmedel/halon-hfc/ ICS (2017). http://www.ics-shipping.org/shipping-facts/key-facts

IMO (2014). Third IMO Greenhouse Gas Study 2014.

http://www.imo.org/en/OurWork/Environment/PollutionPrevention/AirPollution/Documents/ Third\%20Greenhouse\%20Gas\%20Study/GHG3\%2oExecutive\%2oSummary\%2oand\%2oRepo rt.pdf

IMO (2017a). http://www.imo.org/en/About/conventions/listofconventions/pages/internationalconvention-foRthe-prevention-of-pollution-from-ships-(marpol).aspx

IMO (2017b). MARPOL Annex VI, Regulation 12.

http://www.imo.org/en/OurWork/Environment/PollutionPrevention/AirPollution/Pages/Ozon e-depleting-substances-(ODS)-\%E2\%80\%93-Regulation-12.aspx

Javadi M.S., Søndergaard R., Nielsen O.J., Hurley M.D., Wallington T.J. (2008). Atmospheric chemistry of trans- $\mathrm{CF}_{3} \mathrm{CH}=\mathrm{CHF}$ : products and mechanisms of hydroxyl radical and chlorine atom initiated oxidation. Atmos. Chem. Phys. Discuss., 8, 1069-1088, 2008.

https://doi.org/10.5194/acpd-8-1069-2008

JL Marine and Engineering, Pte Ltd (2017). Chilled water unit.

Kidde Sweden (2017). http://www.kidde.se/Pages/Fixed-firefighting-systems.aspx

Larminat, P. (2017). Chiller Technologies for Marine and fishery sectors. Sustainable Management of Refrigeration Technologies in Marine and Off-Shore Fisheries Sectors, 6-8 April, Bangkok.

Larsen, U., Pierobon, L., Haglind, F., Gabrielii, C. (2013). Design and optimisation of organic Rankine cycles for waste heat recovery in marine applications using the principles of natural selection. Energy, 55, 803-812. https://doi.org/10.1016/j.energy.2013.03.021

Levander, O. (2010). Energy efficient cruise and ferry concept. Ship \& Offshore, No 1.

Lloyd's Register (2017). Rules and Regulations for the Classifications of Ships, July 2017.

M-917 (2017). Study on environmental and health effects of HFO refrigerants. Report prepared for the Norwegian Environment Agency, 22 December 2017.

Nautic Expo (2017). http://www.nauticexpo.com/prod/johnson-controls-global-marinenavy/product-31195-499788.html

Opcon (2015). http://opconenergysystem.com/wp-content/uploads/2015/11/Commissioningand-testing-of-first-reference-installation-of-Opcon-technology-foRships.pdf

Pigani, L., Boscolo, M., \& Pagan, N. (2016). Marine refrigeration plants for passenger ships: Low-GWP refrigerants and strategies to reduce environmental impact. Int. Journal of Refrigeration, 64, 80-92. https://doi.org/10.1016/j.ijrefrig.2016.01.016

Sander Poulsen, T. (2011). Nordiske indsatser for R-22 i køleanlæg på skibe. ISBN 978-92-8932191-4. https://doi.org/10.6027/tn2011-503

Schwarz, W., Rhiemeier, J-M. (2007) Final report: The analysis of the emissions of fluorinated greenhouse gases from refrigeration and air conditioning equipment used in the transport sector other than road transport and options for reducing these emissions. Maritime, Rail, and Aircraft Sector. Prepared for the European Commission (DG Environment).

SFS (2006). Förordning (2016:1128) om fluorerade växthusgaser. Miljö- och energidepartementet.

Statistics Norway (2012). The merchant fleet of the Nordic countries http://www.ssb.no/a/english/aarbok/tab/tab-432.html

Svensk Brand- och Säkerhetscertifiering AB (2017). https://www.sbsc.se/

Teknotherm (2012). Cool down the Global Warming, Product Catalogue. https://www.teknotherm.no/wp-content/uploads/2013/o8/Product-catalogue2012_low.pdf 
Teknotherm (2017a). Provision cooling.

Teknotherm (2017b). https://www.teknotherm.no/product/absorption-chillers/

Transportstyrelsen (2014). Tillsynshandboken, 6.92 Fast brandsläckning, Version 2014-03-14 https://www.transportstyrelsen.se/static/thb/WebHelp/tillsynshandboken.htm\#brandskydd/6 _92_Fast_brandsl_ckning.htm

Transportstyrelsen (2017). https://www.transportstyrelsen.se/sv/sjofart/Miljo-ochhalsa/Luftfororening/Ozonfortunnande-amnen/

Zoglia, P., Wärtsilä Ship Power (2013). Gas Storage and Supply Systems. 


\section{Sammanfattning}

Denna rapport behandlar kylanläggningar ombord på fartyg, med fokus på de nordiska länderna och fartygstyperna fiskefartyg, passagerarfartyg samt lastfartyg (avgränsat til tank- och RoRo-fartyg). I fiskefartyg används kylaggregaten huvudsakligen för att kyla eller frysa fångsten, medan i passagerar- och lastfartyg används de främst för att tillgodose passagerare och besättning med luftkonditionering och kyld/fryst proviant. I rapporten presenteras den kartläggning som gjorts i projektet, dels av dagens situation, gällande anläggningsdesign, köldmedieanvändning samt läckage, och dels av alternativa systemlösningar, som är tillgängliga på marknaden och/eller under utveckling, med fokus på naturliga köldmedier.

Den internationella sjöfartsorganisationen (IMO) uppskattar den sammanlagda användningen av HCFC-/HFC-köldmdium i världens handelsflotta (2014) till 70 \% R22, $26 \%$ R 134a och $4 \%$ R404A. I de nordiska länderna är användningen av det ozonnedbrytande R22 förbjudet. Kartläggningen visar att för nordiska passagerar- och lastfartyg är R134a och $\mathrm{R}_{407} \mathrm{C}$ de vanligast använda köldmedierna i AC-anläggningar medan R404A är det klart dominerande köldmediet i kyl-och frysaggregat. I nordiska fiskefartyg används det mer och mer av naturliga köldmedier (ammoniak och koldioxid).

De köldmedier som inte är ozonnedbrytande och som är tillgängliga på marknaden idag är uppdelade i tre grupper; mättade fluorkolväten (HFC), omättade fluorkolväten (HFO) och naturliga köldmedier (ammoniak, koldioxid och kolväten). HFC:er har höga GWP-värden och omfattas därmed av olika utfasningsprogram, såsom EU:s Fgasförordning. HFO:er har låga GWP-värden men säkerhetsriskerna, i form av brandoch hälsofarlighet, i samband med användningen av dessa är inte fullständigt klarlagda. Med tanke på att det upprepade gånger har skett att arbetsmedier som tycktes ha bra egenskaper senare visats sig ge okända negativa effekter bör utfasningen av HFC/HCFC:er ske genom infasning av naturliga köldmedier. Energieffektiviteten, för rätt designade system med naturliga köldmedier, är dessutom högre jämfört med traditionella HFC- eller HFO-system. Säkerhetsrisker kopplade till naturliga köldmedier kan lösas med globalt tillgänglig säkerhetsstrategi och teknologi.

Koldioxid (R744) är det enda köldmediet som är klassificerat som icke-brandfarligt, icke-giftig och med försumbar GWP. Desutom har det goda termodynamiska egenskaper. Det höga arbetstrycket i en R744-anläggning är inte ett teknisk problem utan snarare en fördel eftersom det bidrar till ett kompakt system, vilket är extra viktigt ombord på fartyg. En begränsning med R744 är att dagens kompressorer inte är tillräckligt stora och flera parallella kompressorer är nödvändiga för system med kylkapacitet i MW-storlek. Hos flera tillverkare existerar dock sådana kompressorer i design-stadiet och ett ledande kryssningsrederi har nyligen lagt order på ett R744system för deras proviantkyl/-frysanläggning. 
Rekommendationen, utifrån detta projekt, är att fortsätta och ytterligare stärka den goda forskningen och utvecklingen av system med naturliga köldmedier för fartyg, samt att intensifiera överföringen av kunskap och information till alla intressenter inom denna sektor. Följande åtgärder föreslås därför, med syfte att stödja en snabbare infasning av naturliga köldmedier inom de olika sjöfartssektorerna:

- Informationsutbyte, t ex workshops, med klassificeringssällskap, tillverkare, rederier och myndigheter i de nordiska länderna.

- Nationella/nordiska demonstrationsprojekt ombord på fartyg; installation och utvärdering av nästa-generations kompakta och integrerade kylanläggningar med global spridningspotential.

- Etablering av ett nordiskt center för internationell FoU inom marina kylanläggningar.

- Stöd till vidare utveckling av komponenter såsom R744-kompressorer och värmeväxlare. 


\section{Appendix}

Table 10: List of selected refrigerants

\begin{tabular}{l|l} 
Formula & Type
\end{tabular}

R12 (Freon)

CFC

$\mathrm{R} 22$

HCFC

HFC

10,900

$\mathrm{R} 125$

HFC

HFC

R134a

R152a

$\mathrm{R}_{32}$

HFC

HFC

1,430

R410a

$\mathrm{R}_{404} \mathrm{~A}$

$\mathrm{R}_{407} \mathrm{C}$

$\mathrm{R}_{407 \mathrm{~F}}$

$\mathrm{R}_{417} \mathrm{~A}$

R422A

R422D

R507A

R1234yf

R1234ze

HFC-blend

HFC-blend

HFC-blend

HFC-blend

HFC-blend

HFC-blend

HFC-blend

124

R448A

$\mathrm{HFO}$

$\mathrm{HFO}$

HFO/HFC-blend

HFO/HFC-blend

$\mathrm{HFO} / \mathrm{HFC}$-blend

HFO/HFC-blend

HFO/HFC-blend

675
2,088

R $452 \mathrm{~A}$

$\mathrm{R}_{513} \mathrm{~A}$

Natural

Natural

R29o (Propane)

Natural

Natural

3,922

1,774

1,825

2,346

3,143

2,729

3,985

1,397

601

2,140

631

$\mathrm{R}_{744}\left(\mathrm{CO}_{2}\right)$ 
Nordic Council of Ministers

Nordens Hus

Ved Stranden 18

DK-1061 Copenhagen K

www.norden.org

\section{REFRIGERATION UNITS IN MARINE VESSELS}

Fishing vessels can be equipped with energy efficient refrigeration technology applying natural working fluids. Ammonia refrigeration systems have been the first choice, but $\mathrm{CO}_{2}$ units have also become increasingly common in the maritime sector in the last few years. When retrofitting or implementing $\mathrm{CO}_{2}$ refrigeration plants, less space on board is required and such units allow good service and maintenance.

Nowadays, cruise ship owners prefer $\mathrm{CO}_{2}$ units for the provision refrigeration plants.

Ship owners, responsible for the health and safety of the crew and passengers, must carefully evaluate the usage of flammable low GWP working fluids, due to a high risk that toxic decomposition products are formed, even without the presence of an open flame.

Suggestions for further work include a Nordic Technology Hub for global marine refrigeration R\&D and development support for key components. 